\title{
Effects of Urbanization on Water Quality in the Kansas River, Shunganunga Creek Basin, and Soldier Creek, Topeka, Kansas, October 1993 Through September 1995
}

By LARRY M. POPE and JAMES E. PUTNAM

U.S. GEOLOGICAL SURVEY

Water-Resources Investigations Report 97-4045

Prepared in cooperation with the

CITY OF TOPEKA, KANSAS

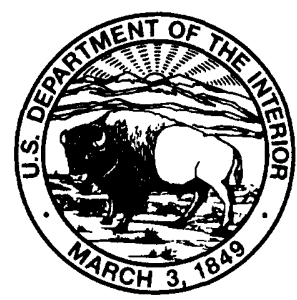




\title{
U.S. DEPARTMENT OF THE INTERIOR
}

BRUCE BABBITT, Secretary

\author{
U.S. GEOLOGICAL SURVEY \\ GORDON P. EATON, Director
}

The use of firm, trade, and brand names in this report is for identification purposes only and does not constitute endorsement by the U.S. Geological Survey.

For additional information write to:

District Chief

U.S. Geological Survey

4821 Quail Crest Place

Lawrence, Kansas 66049-3839
Copies of this report can be purchased from:

U.S. Geological Survey

Information Services

Box 25286

Federal Center

Denver, CO 80225-0826 


\section{CONTENTS}

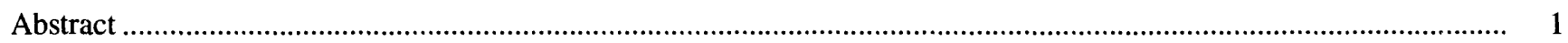

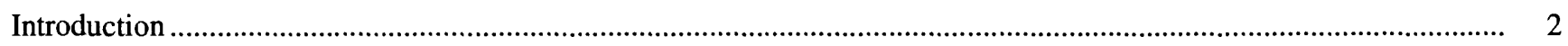

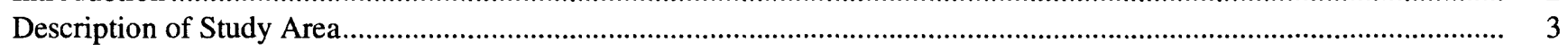

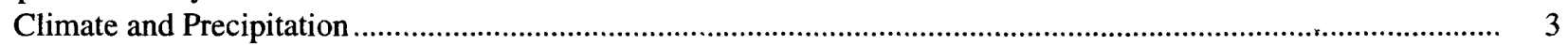

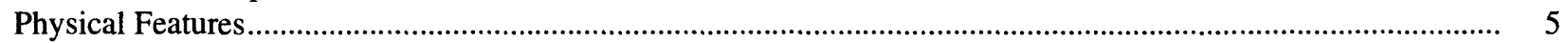

Drainage Patterns, Land Use, and Hydrologic Characteristics .......................................................... 5

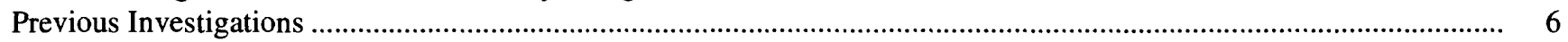

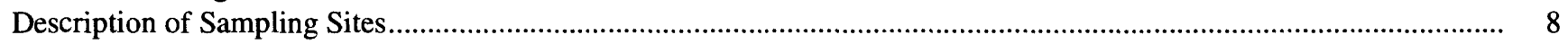

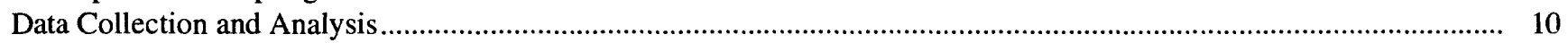

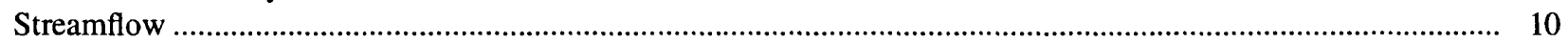

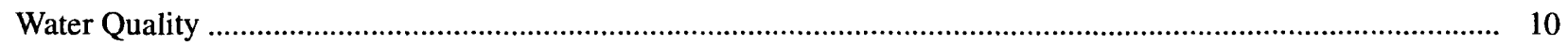

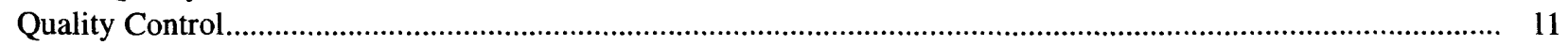

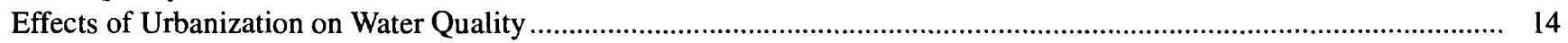

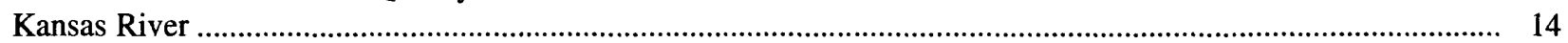

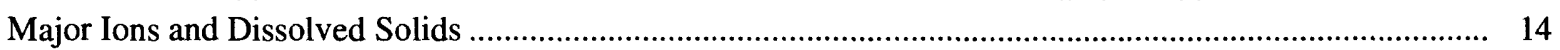

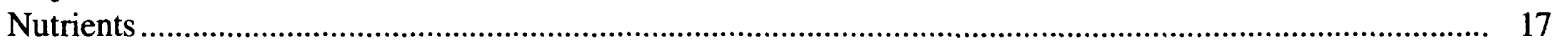

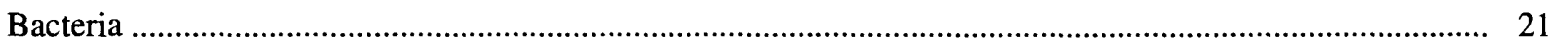

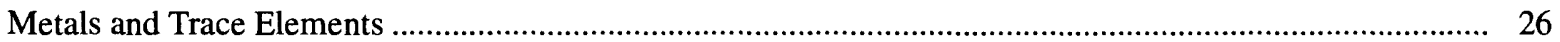

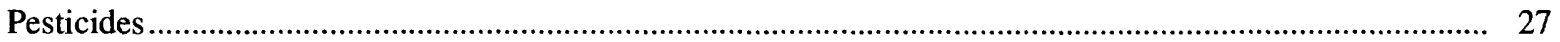

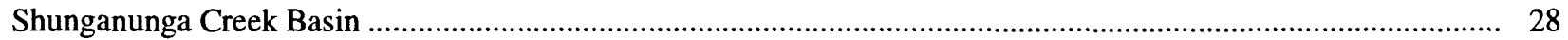

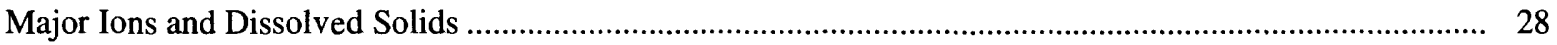

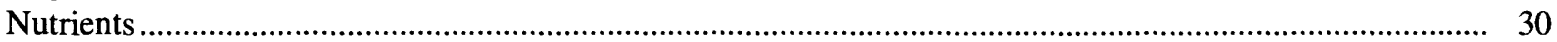

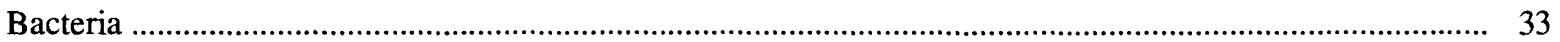

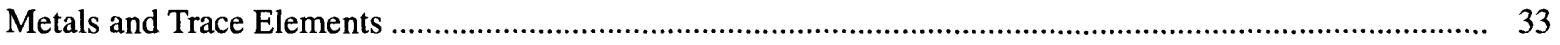

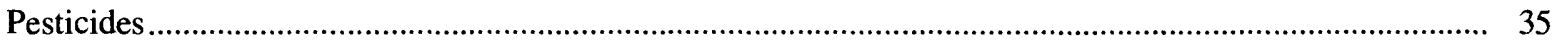

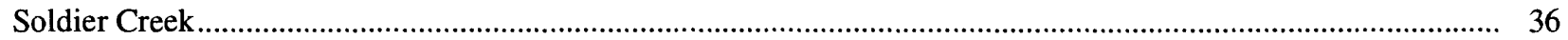

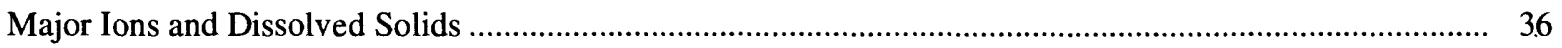

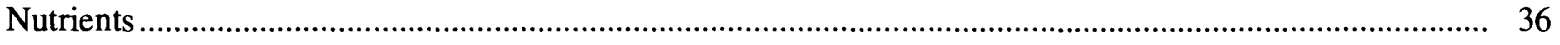

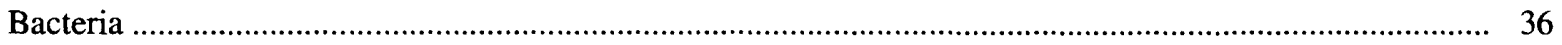

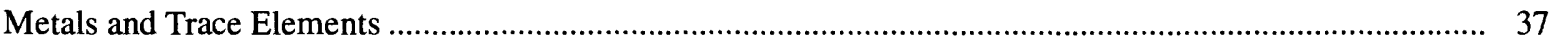

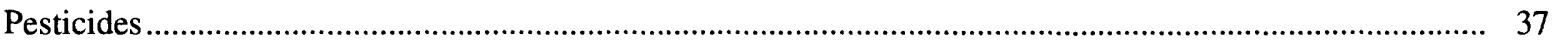

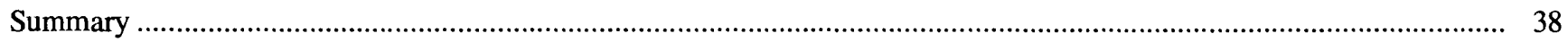

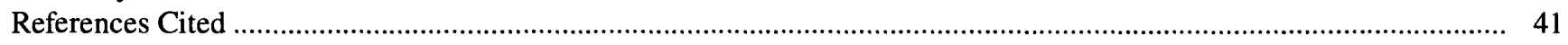

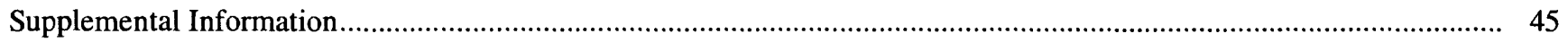

\section{FIGURES}

1. Maps showing location of study area and physiographic sections

2. Graph showing comparison of monthly total precipitation from October 1993 through September 1995 with mean monthly precipitation measured at Topeka, Kansas, for 1961-90.....

3. Map showing extent of urbanization and location of sampling and streamflow-measurement sites in study area

4-21. Graphs showing:

4. Comparison of annual mean streamflow for period of record with annual mean streamflow for the 1994 and 1995 water years at U.S. Geological Survey streamflow-measurement sites in study area......

5. Comparison of median concentrations of major ions and dissolved solids in water from sampling sites KR-1 and KR-2 on the Kansas River and in discharge from the Oakland Wastewater Treatment Plant in Topeka, Kansas, October 1993-September 1995 
6. Comparison of median concentrations of selected nutrients in water from sampling sites KR-1 and KR-2 on the Kansas River and in discharge from the Oakland Wastewater Treatment Plant in Topeka, Kansas, October 1993-September 1995.

7. Comparison of dissolved ammonia as nitrogen concentrations in water from Kansas River sampling site KR-2 with calculated Kansas River concentrations after receiving discharge from the Oakland Wastewater Treatment Plant in Topeka, Kansas, October 1993-September 1995.

8. Calculated dissolved ammonia as nitrogen concentrations in water from the Kansas River after receiving discharge from the Oakland Wastewater Treatment Plant in Topeka, Kansas, as a percentage of waterquality criteria, October 1993-September 1995.

9. Comparison of median densities of fecal coliform and fecal Streptococci bacteria in water from sampling sites KR-1 and KR-2 on the Kansas River and in discharge from the Oakland Wastewater Treatment Plant in Topeka, Kansas, October 1993-September 1995.

10. Comparison of densities of fecal coliform and fecal Streptococci bacteria in water from Kansas River sampling site KR-2 with calculated Kansas River densities after receiving discharge from the Oakland Wastewater Treatment Plant in Topeka, Kansas, October 1993-September 1995.

11. Comparison of median total recoverable concentrations of selected metals and trace elements in water from sampling sites KR-1 and KR-2 on the Kansas River and in discharge from the Oakland Wastewater Treatment Plant in Topeka, Kansas, October 1993-September 1995.

12. Comparison of median concentrations of major ions and dissolved solids in water from sampling sites SH-1, SB-1, and SH-2 in the Shunganunga Creek Basin, Topeka, Kansas, October 1993September 1995

13. Comparison of median concentrations of dissolved solids in dry-weather streamflow from October 1979 through September 1981 with median concentrations from October 1993 through September 1995 in water from sampling sites SH-1, SB-1, and SH-2 in the Shunganunga Creek Basin, Topeka, Kansas

14. Comparison of median concentrations of selected nutrients in water from sampling sites SH-1, SB-1, and SH-2 in the Shunganunga Creek Basin, Topeka, Kansas, October 1993-September 1995.

15. Comparison of median concentrations of selected nutrients in dry-weather streamflow from October 1979 through September 1981 with median concentrations from October 1993 through September 1995 in water from sampling sites SH-1, SB-1, and SH-2 in the Shunganunga Creek Basin, Topeka, Kansas

16. Comparison of median densities of fecal coliform and fecal Streptococci bacteria in water from sampling sites SH-1, SB-1, and SH-2 in the Shunganunga Creek Basin,Topeka, Kansas, October 1993September 1995

17. Comparison of median total recoverable concentrations of selected metals and trace elements in water from sampling sites SH-1, SB-1, and SH-2 in the Shunganunga Creek Basin, Topeka, Kansas, October 1993-September 1995

18. Comparison of median concentrations of major ions and dissolved solids in water from sampling sites KR-2 on the Kansas River, SH-2 on Shunganunga Creek, and SO-1 on Soldier Creek, Topeka, Kansas October 1993-September 1995

19. Comparison of median concentrations of selected nutrients in water from sampling sites KR-2 on the Kansas River, SB-1 on South Branch Shunganunga Creek, and SO-1 on Soldier Creek, Topeka, Kansas, October 1993-September 1995.

20. Comparison of median densities of fecal coliform and fecal Streptococci bacteria in water from sampling sites KR-1 on the Kansas River, SH-2 on Shunganunga Creek, and SO-1 on Soldier Creek, Topeka, Kansas, October 1993-September 1995.

21. Comparison of median total recoverable concentrations of selected metals and trace elements in water from sampling sites KR-2 on the Kansas River, SH-1 on Shunganunga Creek, and SO-1 on Soldier Creek, Topeka, Kansas, October 1993-September 1995

\section{TABLES}

1. Description of sampling sites and drainage areas

2. Date of sample collection, associated streamflow, and percentage of time sampled flow was equalled or exceeded at sampling sites KR-2 and SH-2, October 1993-September 1995 


\section{TABLES-Continued}

3. Statistical summary of analytical variation, in percent, between analyses of duplicate samples for selected water-quality constituents.....

4. Summary of median percent variations between analyses of standard reference samples and mostprobable analytical value for selected water-quality constituents.

5. Summary of analyses of blank water processed as either equipment blanks or as sample-churn blanks.....

6. Streamflow, $\mathrm{pH}$, water temperature, and dissolved ammonia as nitrogen concentrations in water samples from the Kansas River upstream from the Oakland Wastewater Treatment Plant in Topeka, Kansas, discharge and concentrations of dissolved ammonia as nitrogen in water samples from the treatment plant, and calculated concentrations in the Kansas River with discharge from the treatment plant, October 1993-September 1995

7. Streamflow and concentrations of total phosphorus in water samples from the Kansas River upstream from the Oakland Wastewater Treatment Plant in Topeka, Kansas, discharge and concentrations of total phosphorus in water samples from the treatment plant, and calculated concentrations in the Kansas River with discharge from the treatment plant, October 1993-September 1995

8. Streamflow and bacterial densities in water samples from the Kansas River upstream from the Oakland Wastewater Treatment Plant in Topeka, Kansas, discharge and bacterial densities in water samples from the treatment plant, and calculated densities in the Kansas River with discharge from the treatment plant, October 1993-September 1995

9. Probability values calculated by the Wilcoxon rank-sum test comparing total recoverable concentrations of selected metals and trace elements between Kansas River sampling sites KR-1 and KR-2 in Topeka, Kansas ... 28

10. Probability values calculated by the Wilcoxon rank-sum test comparing total recoverable concentrations of selected metals and trace elements between Shunganunga Creek Basin sampling sites SH-1, SB-1, and SH-2 in Topeka, Kansas

11. Statistical summary of water-quality measurements, concentrations of chemical constituents, and bacterial densities for water samples collected from the Kansas River, discharge from the Oakland Wastewater Treatment Plant in Topeka, Kansas, the Shunganunga Creek Basin, and Soldier Creek, October 1993September 1995. 
CONVERSION FACTORS, ABBREVIATIONS, AND DEFINITIONS

\begin{tabular}{rcl}
\hline \multicolumn{1}{c}{ Multiply } & By & \multicolumn{1}{c}{ To obtain } \\
acre & 4,047 & square meter \\
cubic foot per second $\left(\mathrm{ft}^{3} / \mathrm{s}\right)$ & 0.02832 & cubic meter per second \\
inch $(\mathrm{in})$. & 25.4 & millimeter \\
microgram per liter $(\mu \mathrm{g} / \mathrm{L})$ & 1.0 & part per billion \\
mile $(\mathrm{mi})$ & 1.609 & kilometer \\
milligram per liter $(\mathrm{mg} / \mathrm{L})$ & 1.0 & part per million \\
million gallons per day $(\mathrm{Mgal} / \mathrm{d})$ & 0.04381 & cubic meter per second \\
square mile $\left(\mathrm{mi}^{2}\right)$ & 2.590 & square kilometer \\
\hline
\end{tabular}

Temperature can be converted to degrees Celsius $\left({ }^{\circ} \mathrm{C}\right)$ or degrees Fahrenheit $\left({ }^{\circ} \mathrm{F}\right)$ by the equations:

${ }^{\circ} \mathrm{C}=5 / 9\left({ }^{\circ} \mathrm{F}-32\right)$

${ }^{\circ} \mathrm{F}=9 / 5\left({ }^{\circ} \mathrm{C}\right)+32$.

Water Year: A water year is a 12-month period, from October 1 through September 30, designated by the calendar year in which it ends. Years are water years in this report unless otherwise stated. 


\title{
Effects of Urbanization on Water Quality in the Kansas River, Shunganunga Creek Basin, and Soldier Creek, Topeka, Kansas, October 1993 Through September 1995
}

\author{
By Larry M. Pope and James E. Putnam
}

\begin{abstract}
A study of urban-related water-quality effects in the Kansas River, Shunganunga Creek Basin, and Soldier Creek in Topeka, Kansas, was conducted from October 1993 through

September 1995. The purpose of this report is to assess the effects of urbanization on instream concentrations of selected physical and chemical constituents within the city of Topeka. A network of seven sampling sites was established in the study area. Samples principally were collected at monthly intervals from the Kansas River and from the Shunganunga Creek Basin, and at quarterly intervals from Soldier Creek. The effects of urbanization were statistically evaluated from differences in constituent concentrations between sites on the same stream.
\end{abstract}

No significant differences in median concentrations of dissolved solids, nutrients, or metals and trace elements, or median densities of fecal bacteria were documented between sampling sites upstream and downstream from the major urbanized length of the Kansas River in Topeka. Discharge from the city's primary wastewatertreatment plant is the largest potential source of contamination to the Kansas River. This discharge increased concentrations of dissolved ammonia, total phosphorus, and densities of fecal bacteria. Calculated dissolved ammonia as nitrogen concentrations in water from the Kansas River ranged from 0.03 to 1.1 milligrams per liter after receiving treatment-plant discharge. However, most of the calculated concentrations were considerably less than 50 percent of Kansas Department of Health and Environment water-quality criteria, with a median value of 20 percent. Generally, treatment-plant discharge increased calculated total phosphorus concentrations in water from the Kansas River by 0.01 to 0.04 milligram per liter, with a median percentage increase of 7.6 percent. The calculated median densities of fecal coliform and fecal Streptococci bacteria in water from the Kansas River increased from 120 and 150 colonies per 100 milliliters of water, respectively, before treatment-plant discharge to a calculated 4,900 and 4,700 colonies per 100 milliliters of water, respectively, after discharge.

Median concentrations of dissolved solids were not significantly different between three sampling sites in the Shunganunga Creek Basin. Median concentrations of dissolved nitrate as nitrogen, total phosphorus, and dissolved orthophosphate were significantly larger in water from the upstream-most Shunganunga Creek sampling site than in water from either of the other sampling sites in the Shunganunga Creek Basin probably because of the site's proximity to a wastewater-treatment plant. Median concentrations of dissolved nitrate as nitrogen and total phosphorus during 1993-95 at upstream sampling sites were either significantly larger than during 1979-81 in response to increases of wastewater-treatment 
plant discharge or smaller because of the elimination of wastewater-treatment plant discharge. Median concentrations of dissolved ammonia as nitrogen were significantly less during 1993-95 than during 1979-81.

Median concentrations of total aluminum, iron, manganese, and molybdenum were signficantly larger in water from the downstream-most Shunganunga Creek sampling site than in water from the upstream-most sampling site. This probably reflects their widespread use in the urban environment between the upstream and downstream Shunganunga Creek sampling sites.

Little water-quality effect from urbanization was indicated by results from the Soldier Creek sampling site. Median concentrations of most water-quality constituents in water from this sampling site were the smallest in water from any sampling site in the study area.

Herbicides were detected in water from all sampling sites. Some of the more frequently detected herbicides included acetochlor, alachlor, atrazine, cyanazine, EPTC, metolachlor, prometon, simazine, and tebuthiuron. Detected insecticides included chlordane, chlorpyrifos, Diazinon, lindane, and malathion. However, no concentrations exceeded Kansas Department of Health and Environment ambient water-quality criteria.

\section{INTRODUCTION}

The water quality of streams in urban areas may be degraded by the effects and processes associated with urbanization. Point and nonpoint-source discharges of dissolved solids, nutrients, bacteria, metals and trace elements, and pesticides may cause water to be unsuitable for irrigation; pose potential public-health problems in processed drinking water; inhibit growth, reproduction, and diversity of aquatic organisms; and reduce recreational desirability of the streams.

Since 1972, when Congress passed Public Law 92-500 requiring States to investigate possible water-quality degradation problems associated with runoff from urban areas, many studies have been conducted in metropolitan areas throughout the United States. The transport of deicing salts in snowmelt runoff and the effects on stream-water quality were studied in central Connecticut where it was documented that sodium ion concentrations increased by a factor of three or more during the snow season (Rich and Murray, 1990). Other studies have documented urban runoff as a cause of large instream concentrations of nutrients (Dorney, 1986; Pope and Bevans, 1987; Decker and others, 1988; Taylor, 1990; Stewart and Robinson, 1992), bacteria (Decker and others, 1988; Evaldi and others, 1993; Martin, 1995), metals and trace elements (Pope and Bevans, 1987; Veenhuis and Slade, 1990; Norman, 1991; Lopes and Fossum, 1995), and pesticides (Norman, 1991; Lopes and Fossum, 1995).

The city of Topeka, Kansas, has applied for a National Pollution Discharge Elimination System (NPDES) Stormwater Permit. The management plan outlined in the permit application initiated a program for monitoring water quality in Topeka's streams. Before this time, most City water-quality monitoring activities had been the characterization of point-source discharges, such as the Oakland Wastewater Treatment Plant and the North Topeka Wastewater Plant. The purpose of stream monitoring was to characterize the condition of Topeka's streams and to identify water-quality concerns. This information then would be used to assist in the development of local public policy that addressed site-specific water-quality conditions.

In developing the monitoring plan, two land-use concerns were noted:

(1) A recreational trail system has been developed along Shunganunga Creek, increasing the number of people coming near or in contact with the creek.

(2) Runoff from intense commerical development along Wanamaker Road near the western edge of the City discharges into the Kansas River upstream from the water intakes of Topeka's water supply. The water-quality effect of urbanization in this commercial area has significance for protection of the public-water supply.

The city of Topeka has several public-policy issues relative to water quality that have economic and regulatory significance. The information gained in the water-quality monitoring program will be important for developing effective public policy in the future. These policy issues include (Edie Snethen, Director of Public Works, city of Topeka, written commun., 1996): 
(1) Future treatment requirements for the Oakland Wastewater Treatment Plant.

(2) Potential contamination prevention needs along Wanamaker Road to protect the City's water supply. There is a possibility that the downstream end of the drainage area along Wanamaker Road will be developed into a park and trail system along the Kansas River. The park site has been proposed for a wetlands stormwater-treatment demonstration site.

(3) Development of best-management practices (BMPs) within the context of the City's stormwater NPDES permit. These BMPs may include structural modifications of the stormwater conveyance and storage system, modifications of design and development standards, or contamination-prevention regulatory programs.

(4) Under the stormwater NPDES permit, the City must establish a program to locate illicit discharges to the municipal storm sewers and streams and to initiate corrective actions through enforcement of a new stormwater ordinance. The water-quality data compiled from stream monitoring may provide some focus for this program as water-quality problems are identified.

In 1993, the U.S. Geological Survey (USGS) entered into a cooperative agreement with the city of Topeka, Kansas, to determine and evaluate water quality in the urbanized sections of the Kansas River, Shunganunga Creek Basin, and Soldier Creek within the city limits (fig. 1). The purpose of this report is to provide an assessment of the effects of urbanization on instream concentrations of selected physical and chemical constituents within the city of Topeka. Specific objectives of this report are to present an evaluation of: (1) the effects of urbanized areas on the water quality in the Kansas River and Shunganunga Creek through a comparison of analyses from upstream and downstream sampling sites,

(2) the effects of discharge from the Oakland Wastewater Treatment Plant on water quality in the Kansas River,

(3) the effects of urbanization on Soldier Creek, and

(4) the effects of past management decisions.

The scope of this report is limited to evaluations of water-quality characteristics determined during the current study (1993-95) and in comparison to a previous study (Pope and Bevans, 1987); comparison of water-quality characteristics between sampling sites; and an evaluation of potential sources of contamination (point and nonpoint). Point-source contamination has an identifiable origin and enters a stream mainly as discharge from municipal and industrial effluent pipes. Nonpoint-source contamination is extremely diffuse in origin, can come from any land-use area, and, generally, is carried over and through soil and ground cover by rainfall, snowmelt, or irrigation return flow (U.S. Environmental Protection Agency, 1984).

The contribution of contaminants to streams during low flow may come from both point and nonpoint sources; however, during high flow, nonpoint-source runoff may predominate. Althrough the scope of this report includes an evaluation of possible point- and nonpoint-source effects on stream-water quality, few samples were collected during runoff when nonpoint-source effects would be largest. Therefore, conclusions pertaining to the possible effects of nonpoint-source contamination should be used with discretion.

\section{DESCRIPTION OF STUDY AREA}

The study area (fig. 1) is located in Shawnee County, northeast Kansas. The area is delineated by the boundary of the city of Topeka and includes those segments of the Kansas River, Shunganunga Creek Basin, and Soldier Creek contained within this boundary.

\section{Climate and Precipitation}

The climate in northeast Kansas is controlled by the movement of frontal air masses over the open inland-plains topography, and seasonal temperature and precipitation extremes are common. During the summer, temperatures near or above $100^{\circ} \mathrm{F}$ can occur. Winter months are characterized by influxes of cold, dry polar air with temperatures as low as $-20^{\circ} \mathrm{F}$. About 70 percent of the average annual precipitation of 34.7 in. falls during the warm growing season, April through September. Only 10 percent of the average annual precipitation falls as rain during the relatively dry winter months of December through February.

During the 2 years of data collection described in this report, precipitation in Topeka averaged 36.06 in. per water year (October through September) (National Oceanic and Atmospheric Administration, 1993-95), just 2.4 percent more than the long-term annual mean of 35.23 in. (National Oceanic and Atmospheric 


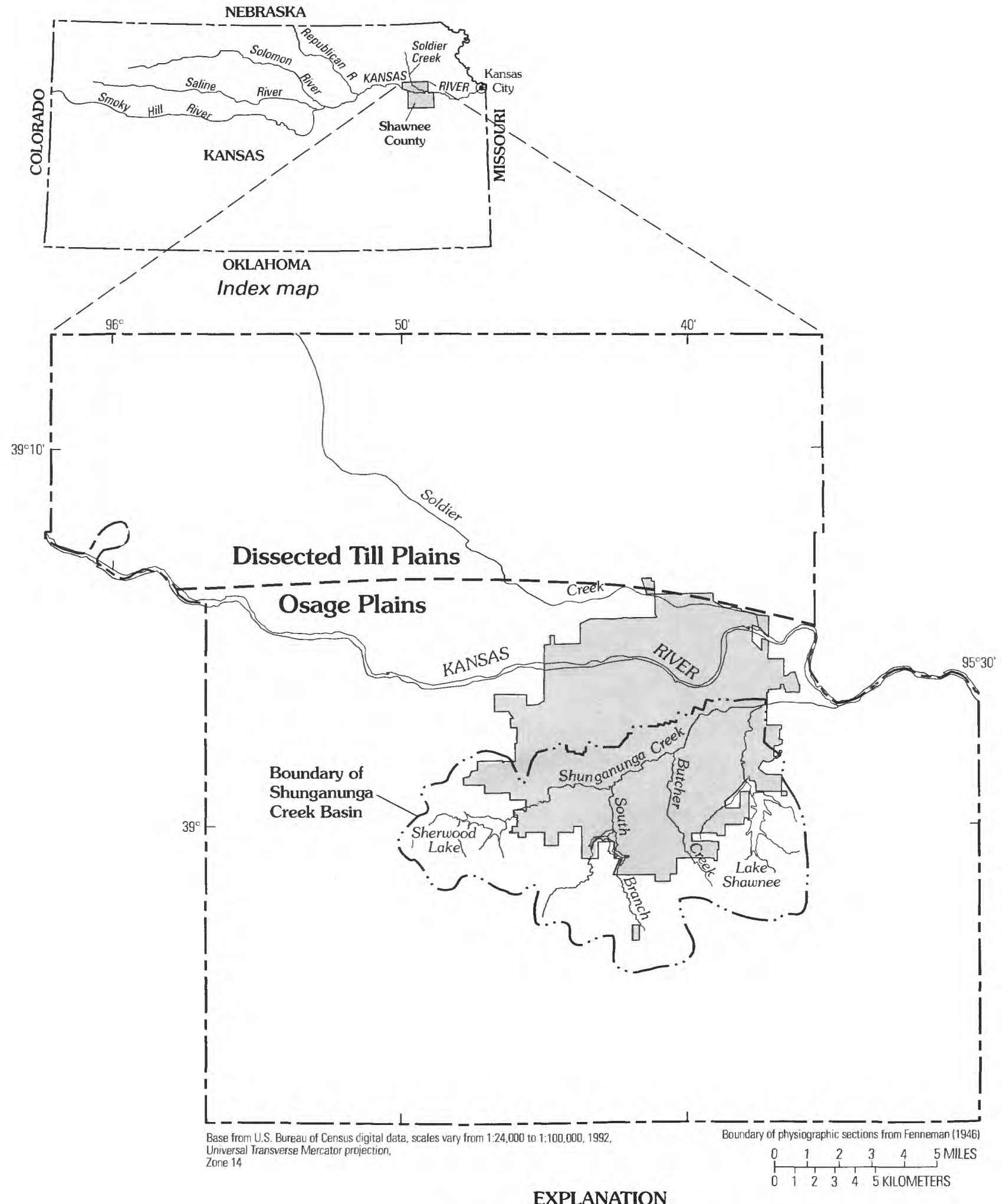

EXPLANATION

Study area (boundary of city of Topeka)

- - Boundary of physiographic section

Figure 1. Location of study area and physiographic sections.

4 Effects of Urbanization on Water Quality in the Kansas River, Shunganunga Creek Basin, and Soldier Creek, Topeka, Kansas, October 1993 Through September 1995 


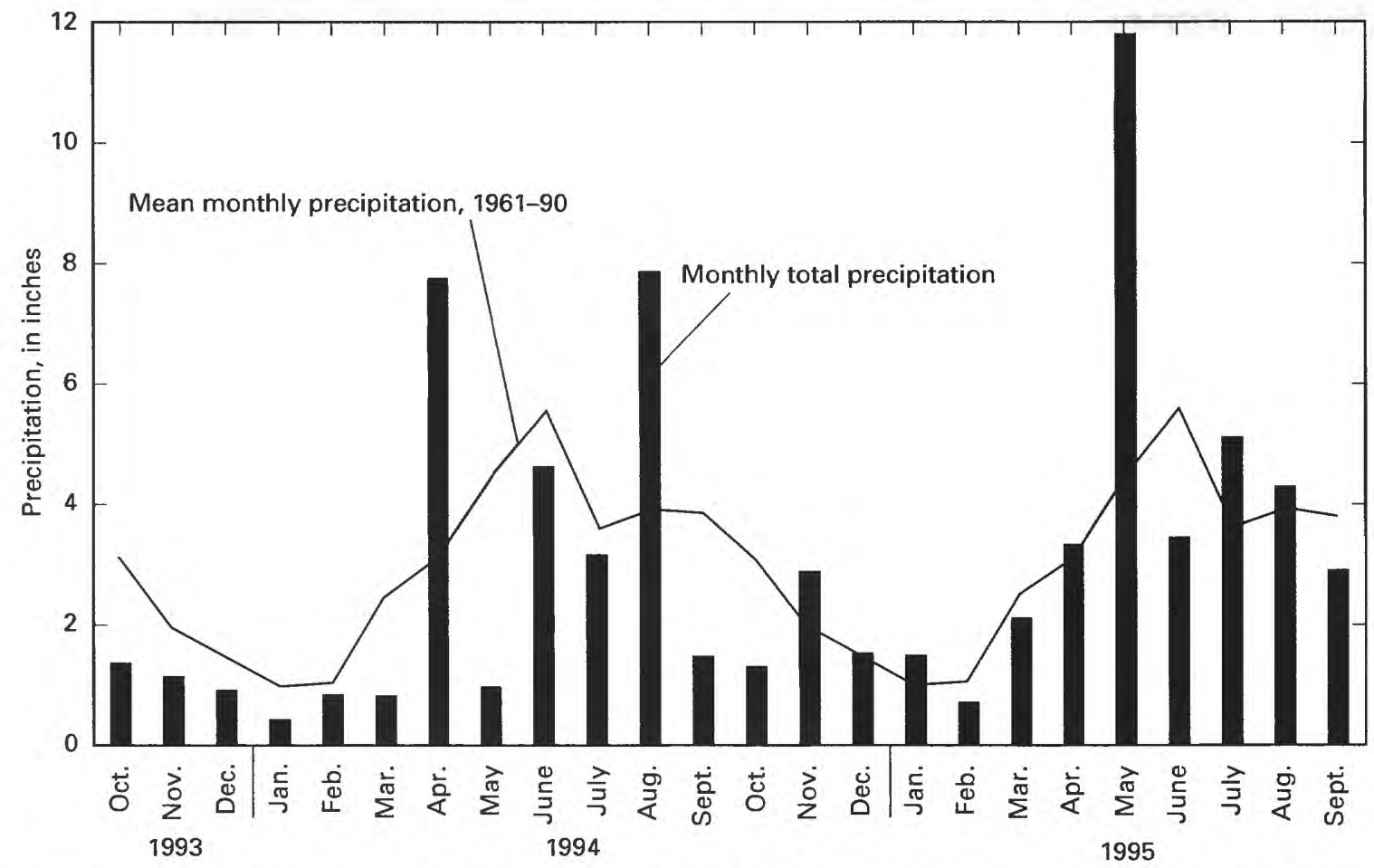

Figure 2. Comparison of monthly total precipitation from October 1993 through September 1995 with mean monthly precipitation measured at Topeka, Kansas, for 1961-90 (data from National Oceanic and Atmospheric Administration, 1992, 1993-95).

Administration, 1992). However, as shown in figure 2, some precipitation extremes were recorded during this study. Precipitation during the 1994 water year was 3.98 in. less than the long-term annual mean due in large part to below-average precipitation from October 1993 through March 1994 but especially due to unusually dry conditions during May 1994. In contrast, precipitation during May 1995 (11.81 in.) was the largest monthly total ever recorded in May. The May 1995 precipitation was primarily responsible for the above-average precipitation (40.86 in.) during the 1995 water year.

\section{Physical Features}

The study area is located in the Dissected Till Plains and Osage Plains Sections of the Central Lowland physiographic province (Fenneman, 1946). The Dissected Till Plains, generally located north of the Kansas River (fig. 1), are characterized by dissected deposits of glacial till that consist of silt, clay, sand, gravel, and boulders that overlie bedrock of primarily shale and limestone with some sandstone. Drainage channels are well entrenched by tributaries flowing south to the Kansas River. The Osage Plains are south of the limit of glaciation and are underlain primarily by shale and limestone. Drainage patterns are well defined although dissection of the land is less than in the Dissected Till Plains (Jordan and Stamer, 1995).

The predominant soil order of the study area is Mollisol. Mollisol soils have a dark surface layer that is high in organic-matter content. Soils in the study area characteristically are deep, moderately drained, level to steeply sloping clay loam with silty clay or clay subsoils (Abmeyer and Campbell, 1970). Most soils in the study area are classified as hydrologic soil group $\mathrm{C}$ or D. These two soil groups, as defined by the U.S. Soil Conservation Service (1975), have a slow infiltration rate when thoroughly wet, which impedes the downward movement of water and results in a moderate to high runoff potential.

\section{Drainage Patterns, Land Use, and Hydrologic Characteristics}

Major streams in the study area (fig. 1) include the Kansas River, Shunganunga Creek, and Soldier Creek. Flow in the Kansas River at Topeka, Kansas, represents 
drainage from a 56,720- $\mathrm{mi}^{2}$ area; however, natural flow is affected by many reservoirs in Colorado, Nebraska, and Kansas, and by numerous upstream diversions. The Kansas River is formed by the confluence of the Republican and Smoky Hill Rivers about 87 river mi upstream from Topeka and, historically, has meandered across a broad, flat valley. However, since 1951 when record flooding inundated many urban and rural areas, the Kansas River has been regulated by a system of levees and flood-control reservoirs built between 1951 and 1978.

Most of the drainage area of the Kansas River is devoted to agricultural uses (crops, pasture, and rangeland), with the most extensive urban area upstream from Kansas City located at Topeka. Major crops include corn, grain sorghum, soybeans, and wheat.

The long-term (1963-95) annual mean streamflow in the Kansas River at Topeka, Kansas (USGS streamflow-measurement site 06889000 , fig. 3) is $6,390 \mathrm{ft}^{3} / \mathrm{s}$ (data on file at USGS in Lawrence, Kansas). Mean annual streamflow for both the 1994 and 1995 water years was greater than the long-term annual mean (fig. 4). Annual mean streamflows in the Kansas River during 1994 and 1995 were 17 percent and 58 percent, respectively, greater than the long-term annual mean.

Unlike the basin of the Kansas River, a large part of the $60-\mathrm{mi}^{2}$ Shunganunga Creek Basin is urbanized. Shunganunga Creek originates southwest of Topeka and generally flows in a northeasterly direction until discharging into the Kansas River 2 mi downstream from the eastern boundary of the study area. During its course to the Kansas River, Shunganunga Creek flows through areas with a variety of land uses. After originating in an agricultural area, the stream flows through an area of single and multifamily housing intermixed with neighborhood commercial developments, through the downtown commercial area, and subsequently through a light-industrial area and out of the study area towards it confluence with the Kansas River.

Flow in Shunganunga Creek is controlled in part by several hundred ponds and small lakes ( 0.5 to 5.0 surface acres) and two major lakes. The small ponds were built to store water supplies for livestock and to control erosion from agricultural areas. The two major lakes, shown in figure 1, were built primarily for flood control, but they also provide for recreational activities such as fishing, swimming, boating, and water skiing. Sherwood Lake, located on Shunganunga Creek in the western part of the study area, has a surface area of about 230 acres and a contributing drain- age area of $6.85 \mathrm{mi}^{2}$. Lake Shawnee in the eastern part of the study area, has a surface area of about 360 acres and a contributing drainage area of $9.12 \mathrm{mi}^{2}$ (Pope and Bevans, 1987).

Although long-term streamflow records, such as available for the Kansas River, do not exist for Shunganunga Creek, the period of record (1980-81, 1994-95) was used in place of a long-term annual mean. The period-of-record annual mean streamflow for Shunganunga Creek at Rice Road, Topeka, Kansas (USGS site 06889700, fig. 3), is compared to 1994 and 1995 water year annual mean streamflows in figure 4. Unlike the Kansas River, the 1994 annual mean streamflow was less than one-half of the period-of-record annual mean and probably is a result of below-average precipitation during the 1994 water year. In contrast, the 1995 annual mean streamflow was 68 percent greater than the period-of-record annual mean. Most of this increase can be attributed to the nearly $12 \mathrm{in.} \mathrm{of} \mathrm{precip-}$ itation in May 1995 (fig. 2). The monthly mean streamflow during May 1995 was $543 \mathrm{ft}^{3} / \mathrm{s}$, compared to the period-of-record mean of $169 \mathrm{ft}^{3} / \mathrm{s}$.

The Soldier Creek drainage area consist of about $290 \mathrm{mi}^{2}$ in three counties of northeast Kansas. The Soldier Creek Valley extends north-northwest of Topeka, is about $48 \mathrm{mi}$ long, and ranges from about $0.5 \mathrm{mi}$ wide in the upstream reaches to about 2 mi wide near its entrance to the Kansas River Valley. The downstream reach of Soldier Creek flows in the valley of the Kansas River for about $10 \mathrm{mi}$ (Carswell, 1978). Land use in the basin is almost exclusively agricultural, with 54 percent cropland, 38 percent pasture, and 8 percent forested area and other uses (Carswell, 1981). The long-term (1936-94) annual mean streamflow in Soldier Creek near Topeka (USGS site 06889500, fig. 3), $6.0 \mathrm{mi}$ upstream from its confluence with the Kansas River, is $154 \mathrm{ft}^{3} / \mathrm{s}$ (Geiger and others, 1995).

\section{PREVIOUS INVESTIGATIONS}

A previous investigation of water-quality characteristics of selected streams in the Shunganunga Creek Basin (Topeka, Kansas) was conducted from October 1979 through September 1981. The purpose of that investigation was to provide the data and interpretation necessary to determine the effects of runoff from urban areas on the water-quality characteristics of receiving streams. That investigation was a cooperative effort between the USGS and the Kansas Department of Health and Environment. Water-quality characteris- 

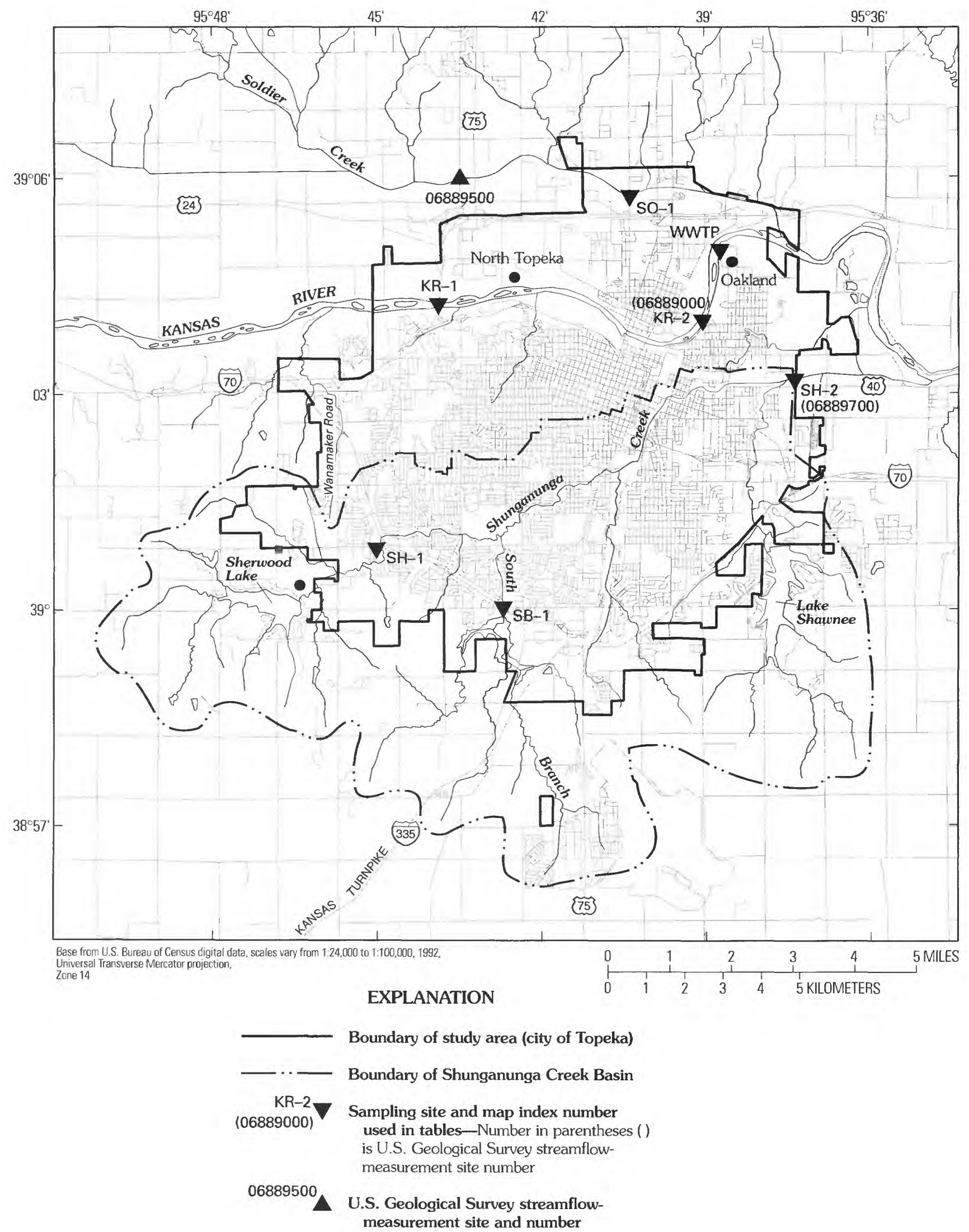

- Wastewater-treatment plant

Figure 3. Extent of urbanization and location of sampling and streamflow-measurement sites in study area. 


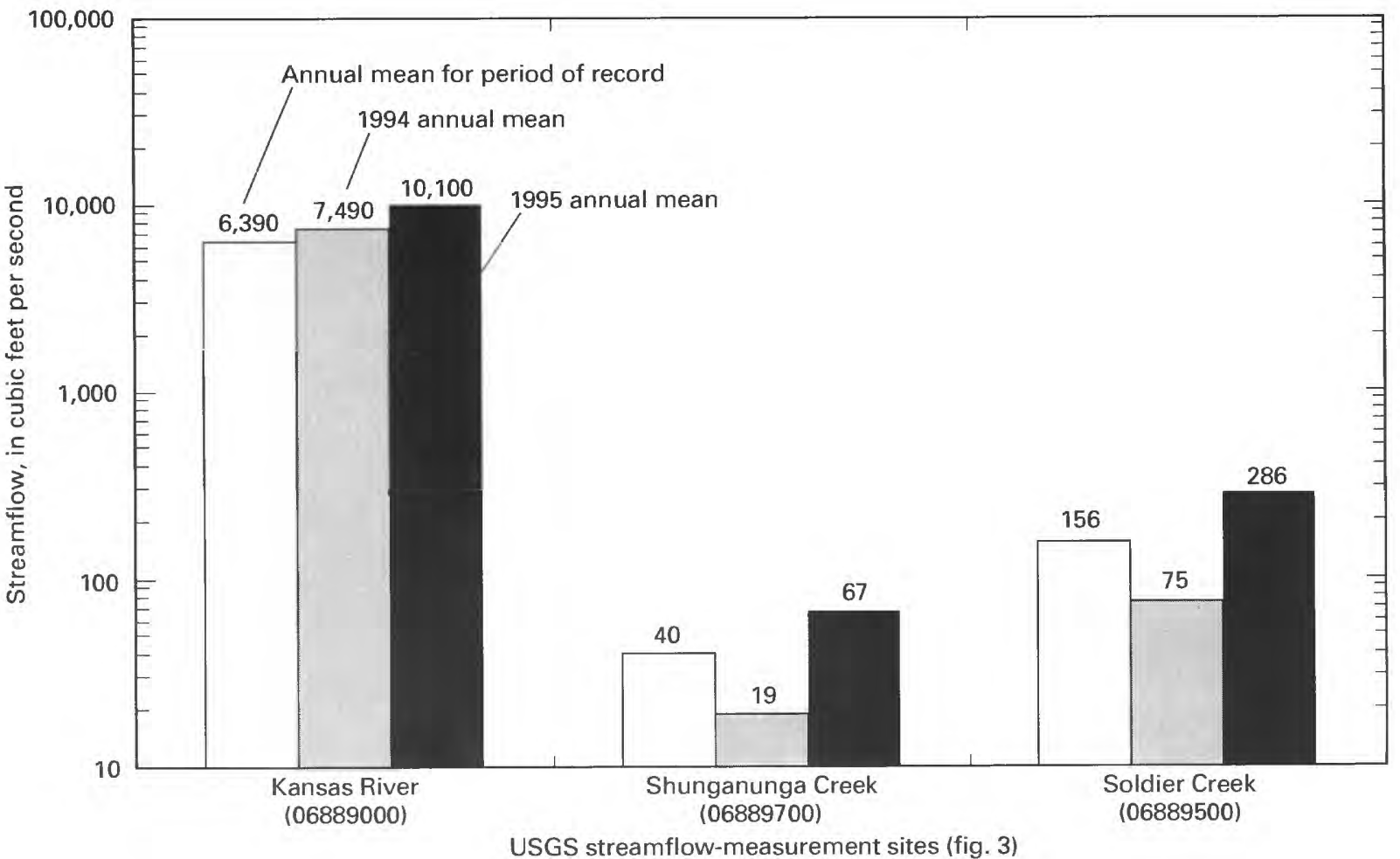

Figure 4. Comparison of annual mean streamflow for period of record with annual mean streamflow for the 1994 and 1995 water years at U.S. Geological Survey (USGS) streamflow-measurement sites in study area.

tics for three streamflow conditions were determined: (1) dry-weather streamflow-a combination of base flow and point-source contributions, (2) storm streamflow-mainly provided by overland runoff from storms, and (3) snowmelt streamflow-mainly provided by overland runoff from snowmelt. Results of this previous investigation are presented in Pope and Bevans (1987).

In 1986, as part of the National Water-Quality Assessment (NAWQA) Program, the USGS began a study of the quality of surface water in a $15,300-\mathrm{mi}^{2}$ area of the lower Kansas River Basin in southeastern Nebraska and northeastern Kansas. Data from the Kansas River at Topeka, Kansas (USGS site 06889000 , fig. 3), was used in that study. Stream-water samples for the determination of concentrations of dissolved solids and major ions, nutrients, bacteria, metals and trace elements, organic carbon, radioactivity, and herbicides and insecticides were collected at this site from May 1987 through April 1990. Samples were collected at least monthly, with additional samples collected to define water-quality characteristics during unusual streamflow conditions. Analytical results for these samples are presented in Fallon and McChesney
(1993). Results of this investigation are presented in Helgesen (1996).

\section{DESCRIPTION OF SAMPLING SITES}

For the purpose of monitoring the effects of urbanization on streams within the city of Topeka, Kansas, a network of seven sampling sites was established. The location of these sampling sites is shown in figure 3 and described in table 1.

Two sampling sites were established on the Kansas River. Sampling site KR-1 (fig. 3), the more upstream of the two, was located near the extreme western boundary of the study area. This site was used to define water-quality constituent concentrations in the Kansas River before entering the major urbanized area of the city. However, about 1.7 mi upstream from sampling site KR-1, the Kansas River receives runoff from a major commercial area through discharge from an unnamed tributary. This commercial area parallels Wanamaker Road along the west edge of Topeka and includes a regional shopping mall, associated strip malls, discount warehouses, gasoline stations, convenience stores, and restaurants. Therefore, water-quality 


\begin{tabular}{|c|c|c|c|c|}
\hline $\begin{array}{l}\text { Map- } \\
\text { index } \\
\text { number } \\
\text { (fig. 3) }\end{array}$ & $\begin{array}{c}\text { U.S. } \\
\text { Geological } \\
\text { Survey site } \\
\text { identification } \\
\text { number }\end{array}$ & Sampling-site name & $\begin{array}{l}\text { Latitude (lat.) and } \\
\text { longitude (long.) }\end{array}$ & $\begin{array}{l}\text { Drainage } \\
\text { area } \\
\text { (square } \\
\text { miles) }\end{array}$ \\
\hline KR-1 & 06888980 & Kansas River at U.S. Highway 75 & $\begin{array}{l}\text { lat. } 39^{\circ} 04^{\prime} 10^{\prime \prime} \mathrm{N} \\
\text { long. } 95^{\circ} 43^{\prime} 50^{\prime \prime} \mathrm{W}\end{array}$ & ${ }^{1} 56,710$ \\
\hline $\mathrm{KR}-2$ & 06889000 & $\begin{array}{l}\text { Kansas River at Topeka (Sardou } \\
\text { Avenue) }\end{array}$ & $\begin{array}{l}\text { lat. } 39^{\circ} 04^{\prime} 00^{\prime \prime} \mathrm{N} \\
\text { long. } 95^{\circ} 38^{\prime} 58^{\prime \prime} \mathrm{W}\end{array}$ & 56,720 \\
\hline WWTP & 06889002 & $\begin{array}{l}\text { Oakland Wastewater Treatment Plant } \\
\text { effluent }\end{array}$ & $\begin{array}{l}\text { lat. } 39^{\circ} 04^{\prime} 19^{\prime \prime} \mathrm{N} \\
\text { long. } 95^{\circ} 38^{\prime} 40^{\prime \prime} \mathrm{W}\end{array}$ & 2 \\
\hline $\mathrm{SO}-1$ & 06889502 & Soldier Creek at Rochester Road & $\begin{array}{l}\text { lat. } 39^{\circ} 05^{\prime} 56^{\prime \prime} \mathrm{N} \\
\text { long. } 95^{\circ} 40^{\prime} 21^{\prime \prime} \mathrm{W}\end{array}$ & $3_{305}$ \\
\hline $\mathrm{SH}-1$ & 06889580 & $\begin{array}{l}\text { Shunganunga Creek at Southwest } \\
\text { 29th Street }\end{array}$ & $\begin{array}{l}\text { lat. } 39^{\circ} 00^{\prime} 51^{\prime \prime} \mathrm{N} \\
\text { long. } 95^{\circ} 44^{\prime} 55^{\prime \prime} \mathrm{W}\end{array}$ & 13.8 \\
\hline SB-1 & 06889610 & $\begin{array}{l}\text { South Branch Shunganunga Creek at } \\
\text { Southwest } 37 \text { th Street }\end{array}$ & $\begin{array}{l}\text { lat. } 39^{\circ} 00^{\prime} 01^{\prime \prime} \mathrm{N} \\
\text { long. } 95^{\circ} 42^{\prime} 42^{\prime \prime} \mathrm{W}\end{array}$ & 13.8 \\
\hline $\mathrm{SH}-2$ & 06889700 & Shunganunga Creek at Rice Road & $\begin{array}{l}\text { lat. } 39^{\circ} 03^{\prime} 12^{\prime \prime} \mathrm{N} \\
\text { long. } 95^{\circ} 37^{\prime} 19^{\prime \prime} \mathrm{W}\end{array}$ & 60.3 \\
\hline \multicolumn{5}{|c|}{${ }^{1}$ Estimated on basis of drainage area at sampling site KR-2. } \\
\hline
\end{tabular}

conditions in the Kansas River at sampling site KR-1 may be affected by this upstream urbanization particularly during periods of localized runoff. Sampling site KR-2 (fig. 3) is located on the Kansas River about 4.7 mi downstream from sampling site KR-1. Samples collected at this site were used to document possible water-quality degradation associated with urbanized areas between sampling sites KR-1 and KR-2.

Sampling site WWTP (fig. 3) is located at the four effluent channels discharging from the Oakland Wastewater Treatment Plant. Discharge from this plant represents the major point source of potential contamination in the study area. The Oakland plant is the city's main wastewater-treatment facility, and its effluent enters the Kansas River about $1 \mathrm{mi}$ downstream from sampling site KR-2. The Oakland plant has a designed discharge of $16.0 \mathrm{Mgal} / \mathrm{d}$ (U.S. Environmental Protection Agency, 1983). Samples collected at site WWTP were used to describe the potential water-quality effect of the city's major point-source discharge to the Kansas River. A second wastewater treatment plant (North Topeka plant) is located on the Kansas River about 3.2 mi upstream from sampling site KR-2. The maximum design discharge from this plant currently (early 1996 ) is $1.25 \mathrm{Mgal} / \mathrm{d}$, with a normal operational discharge of $0.25 \mathrm{Mgal} / \mathrm{d}$ (Kelly Haller, city of Topeka, oral commun., 1996); however, an expansion of this plant is underway and scheduled for completion in summer 1996. Effluent quality from this plant was not monitored during this study.

Sampling site SO-l (fig. 3) is located on Soldier Creek about $2.9 \mathrm{mi}$ upstream from the confluence with the Kansas River. Although most of the Soldier Creek drainage area is devoted to agricultural uses, water quality could be affected by discharges from an industrial area about $1 \mathrm{mi}$ upstream, particularly during low 
flow when nonpoint-source contamination from agricultural runoff is minimal.

Three sampling sites were established in the Shunganunga Creek Basin. All three sampling sites were at locations of a previous water-quality investigation conducted between 1979 and 1981 (Pope and Bevans, 1987). Water-quality data collected during this previous investigation are presented in Pope and others (1983), and streamflow data have been published by the U.S. Geological Survey $(1981,1982)$.

Sampling site SH-1 (fig. 3) was established on the main stem of Shunganunga Creek near the western edge of the study area. Much of the localized drainage area between Lake Sherwood and sampling site SH-1 (fig. 3) is urbanized. Additionally, a wastewater-treatment plant, located near Sherwood Lake, discharges effluent into Shunganunga Creek about 2 mi upstream from sampling site $\mathrm{SH}-1$. This plant has a design capacity of $2.0 \mathrm{Mgal} / \mathrm{d}$, with a normal operating discharge of $0.5 \mathrm{Mgal} / \mathrm{d}$ (Kelly Haller, city of Topeka, oral commun., 1996). Samples collected at sampling site $\mathrm{SH}-1$ were used to document water-quality characteristics resulting from a combination of discharges from Sherwood Lake, the Sherwood Lake Wastewater Treatment Plant, and localized urban development upstream from Shunganunga Creek entering the major urbanized part of Topeka.

Sampling site SB-1 (fig. 3) was established on the South Branch Shunganunga Creek to define water-quality characteristics on the major tributary to Shunganunga Creek. The drainage area of sampling site SB-1, $13.8 \mathrm{mi}^{2}$, represents about 23 percent of the Shunganunga Creek Basin included in this study and consists of a mix of land uses including agricultural, residential, commercial, and light industrial.

Sampling site $\mathrm{SH}-2$ (fig. 3), the downstream-most Shunganunga Creek sampling site, is located at the extreme eastern edge of the study area. This sampling site represents the accumulated flow from a drainage area of $60.3 \mathrm{mi}^{2}$, much of which is urbanized. Samples from this site were used to describe the combined effect of all land uses within the basin and the relative effect of urbanization.

\section{DATA COLLECTION AND ANALYSIS}

Data-collection methods for this study were designed to provide a base of information adequate to calculate daily mean streamflow, and to produce a data base of selected physical and chemical water-quality characteristics adequate to calculate statistics for central tendency (median) for between-site comparisons and to calculate the effect of point-source discharges on receiving streams. A statistical summary of data collected during this study is presented in table 11 in the "Supplemental Information" section of this report.

\section{Streamflow}

Of the seven sampling sites listed in table 1, two had a continuous record of stream stage. Sampling site KR-2 has a continuous record of stream stage since 1961. Sampling site SH-2 was reactivated at the site of a previous water-quality investigation of Shunganunga Creek conducted between 1979 and 1981. Stream stages were recorded in 1-hour intervals at sampling site KR-2 and in 5-minute intervals at sampling site SH-2 and were related to periodic current-meter streamflow measurements (Buchanan and Somers, 1976) to develop and adjust stage-streamflow ratings. These ratings subsequently were used to calculate daily mean streamflow according to methods presented in Kennedy (1983). Values of daily mean streamflow for sampling sites KR-2 and SH-2 are published in Geiger and others (1995) and Putnam and others (1996).

\section{Water Quality}

Samples for determination of selected physical and chemical water-quality characteristics were collected using standard USGS depth- and width-integrating procedures (Edwards and Glysson, 1988) and with adherence to water-quality control sampling and processing procedures as outlined in Horowitz and others (1994). Measurements made onsite by USGS personnel included instantaneous streamflow or discharge, specific conductance, hydrogen-ion activity $(\mathrm{pH})$, water temperature, barometric pressure, dissolved oxygen, and alkalinity (carbonate and bicarbonate concentrations).

Samples were collected about once a month from October 1993 through September 1995 at all sampling sites except SO-1 (table 1). Samples were collected at quarterly intervals at sampling site SO-1. Most samples were collected during periods of stable, dryweather flow (nonrunoff periods); however, about two samples at each site were collected when streamflow was affected by runoff. An expression of streamflow at the time of sample collection as the percentage of time 
that flow is equalled or exceeded, on the basis of long-term record at sampling sites $\mathrm{KR}-2$ and $\mathrm{SH}-2$, is presented in table 2 . Small percentage values indicate large streamflow volumes that occur infrequently, but, for regulated streams like the Kansas River, these values do not necessarily indicate runoff conditions. Some large flows in the Kansas River are the result of discharges from upstream reservoirs, and therefore, water-quality characteristics in the Kansas River may differ substantially from equivalent runoff-produced streamflow. The median value for percentages of time flow equalled or exceeded sampled streamflows for sampling site KR-2 was 30 percent, which indicates that the data set for this site consists of a series of relatively large streamflows. However, as indicated in table 2, only two samples at sampling site KR-2 were affected by recent runoff. The median value for the percentage of time flow equalled or exceeded sampled streamflows for sampling site $\mathrm{SH}-2$, which represents the unregulated Shunganunga Creek, was 53 percent.

During this study, samples were collected by USGS personnel, and most were subsequently analyzed by the city of Topeka water-quality laboratory for major anions and cations, nutrients (nitrogen and phosphorus species), fecal coliform and fecal Streptococci bacteria, and selected metals and trace elements. Analyses of chemical constituents were performed according to methods presented in Fishman (1993) or equivalent methods as presented by the American Public Health Association and others (1985). Bacteriological analyses were performed using membrane-filter methods as described by Britton and Greeson (1989).

Three or four samples were collected at each sampling site during this study for subsequent analysis of Aroclor polychlorinated biphenyls (PCBs) and selected carbamate, organochlorine, organonitrogen, and organophosphate pesticides. These samples were analyzed by the USGS laboratory in Arvada, Colorado, according to methods presented in Wershaw and others (1987) or Fishman (1993).

\section{Quality Control}

Analytical quality control consisted of analyses of duplicate stream samples, analysis of standard reference samples, and analysis of blank-water (highly purified water, free of contamination) samples. Laboratory analytical precision and reproducibility were evaluated by the analyses of duplicate subsamples of selected stream-water samples. These duplicate subsamples were withdrawn from a USGS sample churn containing a flow-weighted composite sample of a stream cross section. The method for collection of flow-weighted composite samples is presented in Edwards and Glyson (1988). The USGS sample churn has provisions for sample agitation during the subsample withdrawal procedure thereby assuring that each subsample is equivalent and representative of the original composite sample in regard to water-quality constituent concentrations. Therefore, analytical variability between duplicate samples will indicate the degree of precision and reproducibility of the methods and techniques used to analyze for selected waterquality constituents.

A statistical summary of the relative analytical variation between analyses of duplicate samples for selected water-quality constituents is presented in table 3 . The variation, as a percent, between constituent concentrations of duplicate samples was calculated as the absolute value of 100 multiplied by the quotient of the difference in duplicate concentrations divided by the summation of duplicate concentrations.

For most constituents listed in table 3, the median variation between duplicate analyses was less than 5 percent, which indicates an acceptable degree of precision and reproducibility. However, the metals, copper, nickel, and zinc had median percent variations ranging between 10 and 14 percent and may indicate deficiencies in analytical methodology or method implementation, or may indicate that the present laboratory technology used in the analyses of some elements will inherently produce larger variations in duplicate analyses. Another explanation for the larger variations in copper, nickel, and zinc duplicate analyses may be variations in subsamples withdrawn from the sediment churn; however, because these relatively large variations occurred with only 3 of 12 trace metals, this explanation appears unlikely.

The accuracy of laboratory analyses for selected water-quality constituents was evaluated on the basis of variation between the analyses of standard reference samples and the most-probable values (MPV) for those constituents (table 4). Percent variation between the MPV and analytical results of the standard reference samples was determined by calculating the absolute value of 100 multiplied by the quotient of the difference between the MPV and the analytical result of the standard reference sample divided by the MPV. During this study, one or three standard reference samples were analyzed for selected water-quality constituents. 
Table 2. Date of sample collection, associated streamflow, and percentage of time sampled flow was equalled or exceeded at sampling sites $\mathrm{KR}-2$ and $\mathrm{SH}-2$, October 1993-September 1995

[Data on file at U.S.Geological Survey, Lawrence, Kansas; $\mathrm{ft}^{3} / \mathrm{s}$, cubic feet per second]

\begin{tabular}{|c|c|c|c|c|c|}
\hline \multicolumn{3}{|c|}{ Sampling site KR-2 (fig. 3) } & \multicolumn{3}{|c|}{ Sampling site SH-2 (fig. 3) } \\
\hline $\begin{array}{c}\text { Date of } \\
\text { sample } \\
\text { (month-day- } \\
\text { year) }\end{array}$ & $\begin{array}{c}\text { Instanta- } \\
\text { neous } \\
\text { streamflow } \\
\left(\mathrm{ft}^{3} / \mathrm{s}\right)\end{array}$ & $\begin{array}{c}\text { Percentage } \\
\text { of time } \\
\text { sampled flow } \\
\text { equalled or } \\
\text { exceeded }\end{array}$ & $\begin{array}{c}\text { Date of } \\
\text { sample } \\
\text { (month-day- } \\
\text { year) }\end{array}$ & $\begin{array}{c}\text { Instanta- } \\
\text { neous } \\
\text { streamflow } \\
\left(\mathrm{ft}^{3} / \mathrm{s}\right)\end{array}$ & $\begin{array}{c}\text { Percentage } \\
\text { of time } \\
\text { sampled flow } \\
\text { equalled or } \\
\text { exceeded }\end{array}$ \\
\hline $10-20-93$ & 11,700 & 15 & $10-27-93$ & 5.6 & 55 \\
\hline $11-18-93$ & 10,100 & 17 & $11-15-93$ & 16 & 26 \\
\hline $12-09-93$ & 10,100 & 17 & $12-07-93$ & 5.9 & 53 \\
\hline $01-12-94$ & 7,430 & 24 & 01-19-94 & 6.1 & 53 \\
\hline $02-15-94$ & 5,500 & 30 & $02-11-94$ & 4.4 & 65 \\
\hline $03-31-94$ & 5,200 & 32 & $03-31-94$ & 3.5 & 75 \\
\hline $04-21-94$ & 4,800 & 34 & $04-20-94$ & 8.2 & 43 \\
\hline $05-12-94$ & 8,880 & 20 & $05-11-94$ & 23 & 20 \\
\hline 06-09-94 & ${ }^{3} 11,500$ & 15 & $06-08-94$ & ${ }^{3} 591$ & 1.2 \\
\hline $06-28-94$ & 6,350 & 27 & $06-29-94$ & 3.0 & 78 \\
\hline 07-19-94 & 4,770 & 34 & $07-20-94$ & 2.6 & 85 \\
\hline $08-11-94$ & 4,100 & 38 & $08-10-94$ & 1.6 & 93 \\
\hline $08-31-94$ & 3,250 & 45 & $08-30-94$ & 11 & 34 \\
\hline $09-29-94$ & 1,090 & 85 & $09-22-94$ & 19 & 22 \\
\hline $10-17-94$ & 1,460 & 76 & $10-21-94$ & 1.2 & 96 \\
\hline $11-14-94$ & 1,430 & 76 & $11-17-94$ & 1.7 & 92 \\
\hline $12-13-94$ & 3,650 & 42 & $12-12-94$ & 3.4 & 77 \\
\hline $01-12-95$ & 1,890 & 67 & $01-10-95$ & 3.3 & 78 \\
\hline $02-06-95$ & 3,240 & 45 & $02-09-95$ & 4.6 & 64 \\
\hline $03-30-95$ & 4,710 & 34 & $03-29-95$ & 7.4 & 47 \\
\hline $04-18-95$ & 9,160 & 19 & $04-17-95$ & 44 & 13 \\
\hline $05-30-95$ & ${ }^{3} 40,200$ & 1.4 & $05-23-95$ & ${ }^{3} 2,720$ & .2 \\
\hline $06-22-95$ & 41,300 & 1.3 & $06-21-95$ & 13 & 30 \\
\hline $07-12-95$ & 12,100 & 14 & $07-11-95$ & 7.0 & 49 \\
\hline $08-15-95$ & 6,790 & 25 & $08-17-95$ & 22 & 20 \\
\hline $09-12-95$ & 2,700 & 52 & $09-13-95$ & 3.3 & 78 \\
\hline
\end{tabular}

${ }^{1}$ On the basis of daily mean streamflow for water years 1963-95.

${ }^{2}$ On the basis of daily mean streamflow record for the water years 1980-81, 1994-95.

${ }^{3}$ Streamflow affected by recent runoff. 
Table 3. Statistical summary of analytical variation, in percent, between analyses of duplicate samples for selected water-quality constituents

\begin{tabular}{|c|c|c|c|c|}
\hline Water-quality constituent & $\begin{array}{l}\text { Number } \\
\text { of dupli- } \\
\text { cate } \\
\text { analy- } \\
\text { ses }^{1}\end{array}$ & $\begin{array}{c}\text { Median } \\
\text { (per- } \\
\text { cent) }\end{array}$ & $\begin{array}{l}\text { Mini- } \\
\text { mum } \\
\text { (per- } \\
\text { cent) }\end{array}$ & $\begin{array}{l}\text { Maxi- } \\
\text { mum } \\
\text { (per- } \\
\text { cent) }\end{array}$ \\
\hline Calcium, total recoverable & 9 & 1.4 & 0 & 39 \\
\hline Magnesium, total recoverable & 9 & .73 & 0 & 6.7 \\
\hline Sodium, total recoverable & 9 & 0 & 0 & 4.8 \\
\hline Potassium, total recoverable & 9 & 1.4 & 0 & 3.7 \\
\hline Sulfate, filtered & 9 & 3.2 & 0 & 10 \\
\hline Chloride, filtered & 9 & 0 & 0 & 6.2 \\
\hline Solids, residue at 105 degrees Celsius, dissolved & 8 & .91 & .33 & 18 \\
\hline Solids, residue at 105 degrees Celsius, suspended & 9 & 7.4 & 0 & 49 \\
\hline Nitrogen, nitrate, filtered & 6 & 1.5 & 0 & 6.7 \\
\hline Nitrogen, nitrite, filtered & 7 & 3.2 & 0 & 11 \\
\hline Nitrogen, ammonia, filtered & 7 & 1.2 & 0 & 7.7 \\
\hline Nitrogen, ammonia plus organic, total & 8 & 2.2 & 0 & 22 \\
\hline Phosphorus, total & 8 & 1.5 & 0 & 4.9 \\
\hline Phosphorus, ortho, filtered & 9 & .44 & 0 & 7.9 \\
\hline Coliform, bacteria, fecal & 6 & 11 & 3.7 & 43 \\
\hline Streptococci, bacteria, fecal & 8 & 8.5 & .66 & 79 \\
\hline Aluminum, total recoverable & 9 & 3.2 & 0 & 43 \\
\hline Arsenic, total recoverable & 9 & 0 & 0 & 0 \\
\hline Barium, total recoverable & 6 & 0 & 0 & 11 \\
\hline Chromium, total recoverable & 8 & 2.6 & 0 & 33 \\
\hline Cobalt, total recoverable & 3 & 0 & 0 & 20 \\
\hline Copper, total recoverable & 8 & 10 & 0 & 48 \\
\hline Iron, total recoverable & 9 & 2.3 & 0 & 17 \\
\hline Lead, total recoverable & 7 & 0 & 0 & 33 \\
\hline Manganese, total recoverable & 9 & 0 & 0 & 4.3 \\
\hline Molybdenum, total recoverable & 9 & 2.9 & 0 & 11 \\
\hline Nickel, total recoverable & 9 & 14 & 0 & 69 \\
\hline Zinc, total recoverable & 9 & 12 & 0 & 60 \\
\hline
\end{tabular}

'Only analytical pairs with both values greater than the analytical detection limit were included.

Only results for those constituents with three standard reference sample analyses are summarized in table 4. The median percent variations for most of the constituents listed in table 4 were less than 10 percent.

However, median percent variations for total recoverable concentrations of potassium, arsenic, cadmium, chromium, and lead were greater than 10 percent, with lead greater than 20 percent.

The standard reference sample program conducted during this study was a modest effort consisting of only one or three samples. The results presented in table 4 may or may not be indicative of results had a more comprehensive program been conducted. Therefore, conclusions about laboratory analytical accuracy should be made with caution particularly in regard to those constituents that displayed relatively large percent variations.

The possibility of sample contamination resulting from equipment or methods used to collect and process samples was examined through the analysis of blank-water samples processed as either an equipment blank or as a sediment-churn blank. An equipment blank is a sample of blank water that has been processed through the same procedures as an environmental sample to include passing through the samplecollection device, compositing in the sediment churn, and subsampling into separate bottles with appropriate sample preservatives. In effect, an equipment blank 
Table 4. Summary of median percent variations between analyses of standard reference samples and most-probable analytical value for selected water-quality constituents

\begin{tabular}{lcc}
\hline \multicolumn{1}{c}{ Water-quality constituent } & $\begin{array}{c}\text { Num- } \\
\text { ber of } \\
\text { refer- } \\
\text { ence } \\
\text { sam- } \\
\text { ples }\end{array}$ & $\begin{array}{c}\text { Me- } \\
\text { dian } \\
\text { per- } \\
\text { cent } \\
\text { varia- } \\
\text { tion }\end{array}$ \\
\hline Calcium, total recoverable & 3 & 6.5 \\
Magnesium, total recoverable & 3 & 5.8 \\
Sodium, total recoverable & 3 & 2.1 \\
Potassium, total recoverable & 3 & 14 \\
Aluminum, total recoverable & 3 & 6.6 \\
Arsenic, total recoverable & 3 & 14 \\
Barium, total recoverable & 3 & 2.8 \\
Cadmium, total recoverable & 3 & 14 \\
Chromium, total recoverable & 3 & 12 \\
Cobalt, total recoverable & 3 & 7.8 \\
Copper, total recoverable & 3 & 2.1 \\
Iron, total recoverable & 3 & 3.3 \\
Lead, total recoverable & 3 & 23.1 \\
Manganese, total recoverable & 3 & 7.7 \\
Molybdenum, total recoverable & 3 & 6.5 \\
Silver, total recoverable & 3 & 3.5 \\
Zinc, total recoverable & 3 & 1.0 \\
\hline
\end{tabular}

represents all possible sources of contamination of a sample. A sample-churn blank is processed the same as an equipment blank except that the blank water is not passed through the sample-collection device.

A summary of analysis of equipment blanks and sample-churn blanks is presented in table 5 . Generally, sample-collection and processing procedures were not a source of substantial contamination of environmental samples. Of all the analytical determinations (449) indicated in table 5 , only 35 determinations ( 7.8 percent) had detectable concentrations. Furthermore, those detectable concentrations tended to be small relative to concentrations in environmental samples (table 11, "Supplemental Information" section).

\section{EFFECTS OF URBANIZATION ON WATER QUALITY}

\section{Kansas River}

To evaluate the effects of urbanization on water quality in the Kansas River, median concentrations of selected water-quality constituents were calculated on the basis of samples collected from October 1993 through September 1995 for the two Kansas River sampling sites (KR-1 and KR-2) and for discharge from the Oakland Wastewater Treatment Plant (sampling site WWTP). Comparisons of median concentrations between sampling sites $K R-1$ and $K R-2$ were made to evaluate potential water-quality degradation from point and nonpoint sources resulting from urbanization. Concentrations of effluent samples collected at sampling site WWTP were used to calculate resulting Kansas River concentrations after receiving this effluent. A statistical summary of concentrations of selected water-quality constituents for sampling sites $\mathrm{KR}-1$, $\mathrm{KR}-2$, and WWTP are presented in table 11 in the "Supplemental Information" section of this report.

\section{Major lons and Dlssolved Sollds}

The occurrence of major ions and dissolved solids (dissolved salts and minerals) in streams is primarily the result of natural geochemical processes associated with the dissolution of rocks, minerals, and atmospheric gases (Hem, 1985); however, urbanization can be a nonpoint source of major ions and dissolved solids to local streams through such activities as road deicing, residential or commercial dumping of salt-containing solutions into storm sewers, or industrial discharges. A comparison of median concentrations of major cations, anions, and dissolved solids in water from sampling sites $K R-1, K R-2$, and WWTP is presented in figure 5 .

The Wilcoxon rank sum test was used to test for significant differences in median concentrations of dissolved solids between sampling sites KR-1 and KR-2 . The test is a nonparametric test for independent data sets and is an easily computed alternative to the 
Table 5. Summary of analyses of blank water processed as either equipment blanks or as sample-churn blanks [mg/L, milligrams per liter; ${ }^{\circ} \mathrm{C}$, degrees Celsius; cols/100 mL, colonies per 100 milliliters of water; $\mu \mathrm{g} / \mathrm{L}$, micrograms per liter; --, no data]

\begin{tabular}{|c|c|c|c|c|c|c|c|c|}
\hline \multirow[b]{3}{*}{ Water-quality constituent } & \multicolumn{4}{|c|}{ Equipment blanks } & \multicolumn{4}{|c|}{ Sample-churn blanks } \\
\hline & \multirow{2}{*}{$\begin{array}{l}\text { Num- } \\
\text { ber of } \\
\text { analy- } \\
\text { ses }\end{array}$} & \multicolumn{3}{|c|}{ Detectable concentrations } & \multirow{2}{*}{$\begin{array}{c}\text { Num- } \\
\text { ber of } \\
\text { analy- } \\
\text { ses }\end{array}$} & \multicolumn{3}{|c|}{ Detectable concentrations } \\
\hline & & $\begin{array}{c}\text { Num- } \\
\text { ber }\end{array}$ & $\begin{array}{l}\text { Mini- } \\
\text { mum }\end{array}$ & $\begin{array}{l}\text { Maxi- } \\
\text { mum }\end{array}$ & & $\begin{array}{c}\text { Num- } \\
\text { ber }\end{array}$ & $\begin{array}{l}\text { Mini- } \\
\text { mum }\end{array}$ & $\begin{array}{l}\text { Maxi- } \\
\text { mum }\end{array}$ \\
\hline Calcium, total recoverable, $\mathrm{mg} / \mathrm{L}$ & 8 & 0 & -- & -- & 7 & 0 & -- & -- \\
\hline Magnesium, total recoverable, $\mathrm{mg} / \mathrm{L}$ & 8 & 0 & -- & -- & 7 & 0 & -- & -- \\
\hline Sodium, total recoverable, $\mathrm{mg} / \mathrm{L}$ & 8 & 1 & 1.0 & 1.0 & 7 & 0 & -- & -- \\
\hline Potassium, total recoverable, $\mathrm{mg} / \mathrm{L}$ & 8 & 0 & -- & -- & 7 & 0 & -- & -- \\
\hline Sulfate, filtered, $\mathrm{mg} / \mathrm{L}$ & 7 & 2 & 1.0 & 4.9 & 7 & 3 & 4.6 & 38 \\
\hline Chloride, filtered, $\mathrm{mg} / \mathrm{L}$ & 8 & 0 & -- & -- & 7 & 0 & -- & -- \\
\hline Solids, residue at $105^{\circ} \mathrm{C}$, dissolved, $\mathrm{mg} / \mathrm{L}$ & 8 & 1 & 16 & 16 & 7 & 4 & 8.0 & 27 \\
\hline Solids, residue at $105^{\circ} \mathrm{C}$, suspended, mg/L & 7 & 3 & 2.0 & 23 & 6 & 1 & 3.0 & 3.0 \\
\hline Nitrogen, nitrate, filtered, $\mathrm{mg} / \mathrm{L}$ & 7 & 0 & -- & -- & 7 & 0 & -- & -- \\
\hline Nitrogen, nitrite, filtered, $\mathrm{mg} / \mathrm{L}$ & 7 & 0 & -- & -- & 6 & 0 & -- & -- \\
\hline Nitrogen, ammonia, filtered, mg/L & 7 & 2 & .10 & .20 & 7 & 0 & -- & -- \\
\hline Nitrogen, ammonia plus organic, total, $\mathrm{mg} / \mathrm{L}$ & 8 & 1 & 1.1 & 1.1 & 6 & 1 & .20 & .20 \\
\hline Phosphorus, total, mg/L & 7 & 2 & .10 & .10 & 7 & 1 & .04 & .04 \\
\hline Phosphorus, ortho, filtered, mg/L & 8 & 0 & -- & -- & 7 & 1 & .02 & .02 \\
\hline Coliform, bacteria, fecal, cols/100 mL & 3 & 0 & - & -- & 3 & 0 & -- & -- \\
\hline Streptococci, bacteria, fecal, cols/100 mL & 3 & 0 & -- & -- & 3 & 0 & -- & -- \\
\hline Aluminum, total recoverable, $\mu \mathrm{g} / \mathrm{L}$ & 8 & 3 & 3.0 & 10 & 7 & 2 & 40 & 80 \\
\hline Arsenic, total recoverable, $\mu \mathrm{g} / \mathrm{L}$ & 8 & 1 & 4.0 & 4.0 & 7 & 0 & -- & -- \\
\hline Barium, total recoverable, $\mu \mathrm{g} / \mathrm{L}$ & 5 & 0 & -- & -- & 6 & 0 & -- & -- \\
\hline Cadmium, total recoverable, $\mu \mathrm{g} / \mathrm{L}$ & 8 & 0 & -- & -- & 7 & 0 & -- & -- \\
\hline Chromium, total recoverable, $\mu \mathrm{g} / \mathrm{L}$ & 8 & 0 & -- & -- & 7 & 0 & -- & -- \\
\hline Cobalt, total recoverable, $\mu \mathrm{g} / \mathrm{L}$ & 8 & 0 & -- & -- & 7 & 0 & -- & -- \\
\hline Copper, total recoverable, $\mu \mathrm{g} / \mathrm{L}$ & 8 & 0 & -- & -- & 7 & 1 & 5.0 & 5.0 \\
\hline Iron, total recoverable, $\mu \mathrm{g} / \mathrm{L}$ & 8 & 0 & -- & -- & 7 & 3 & 8.0 & 60 \\
\hline Lead, total recoverable, $\mu \mathrm{g} / \mathrm{L}$ & 8 & 1 & 3.0 & 3.0 & 7 & 1 & 1.0 & 1.0 \\
\hline Manganese, total recoverable, $\mu \mathrm{g} / \mathrm{L}$ & 8 & 0 & -- & -- & 7 & 0 & -- & -- \\
\hline Mercury, total recoverable, $\mu \mathrm{g} / \mathrm{L}$ & 8 & 0 & -- & -- & 7 & 0 & -- & -- \\
\hline Molybdenum, total recoverable, $\mu \mathrm{g} / \mathrm{L}$ & 8 & 0 & -- & -- & 7 & 0 & -- & -- \\
\hline Nickel, total recoverable, $\mu \mathrm{g} / \mathrm{L}$ & 8 & 0 & -- & -- & 7 & 0 & -- & -- \\
\hline Selenium, total recoverable, $\mu \mathrm{g} / \mathrm{L}$ & 8 & 0 & -- & -- & 7 & 0 & -- & -- \\
\hline Silver, total recoverable, $\mu \mathrm{g} / \mathrm{L}$ & 8 & 0 & -- & -- & 7 & 0 & -- & -- \\
\hline Zinc, total recoverable, $\mu \mathrm{g} / \mathrm{L}$ & 8 & 0 & -- & -- & 7 & 0 & -- & -- \\
\hline
\end{tabular}

parametric t-test for independence. The Wilcoxon rank-sum test has two main advantages over the t-test: (1) the two data sets are not required to be normally distributed, and

(2) the test can handle censored data (values less than the analytical detection limits) by treating them as ties during the ranking process (Gilbert, 1987).

The results of Wilcoxon rank-sum tests presented in this report are in the form of a probability value ( $p$-value). The $p$-value is a measure of the credibility of the null hypothesis $\left(\mathrm{H}_{\mathrm{o}}\right)$. The $\mathrm{H}_{\mathrm{o}}$ is that the central tendency (median value) of a population of concentrations from a sampling site is not different than the median value of a population of concentrations from another sampling site for an arbitrarily assigned significance level, $\alpha,\left(\alpha=0.05\right.$ in this report). If the credibility of $\mathrm{H}_{\mathrm{o}}$ is less than $\alpha$ for a one-tailed test or less than $\alpha / 2$ (0.025) for a two-tailed test, then $\mathrm{H}_{\mathrm{o}}$ is rejected in favor of the alternative hypothesis $\left(\mathrm{H}_{1}\right)$ that the central tendency of one population is significantly different from 


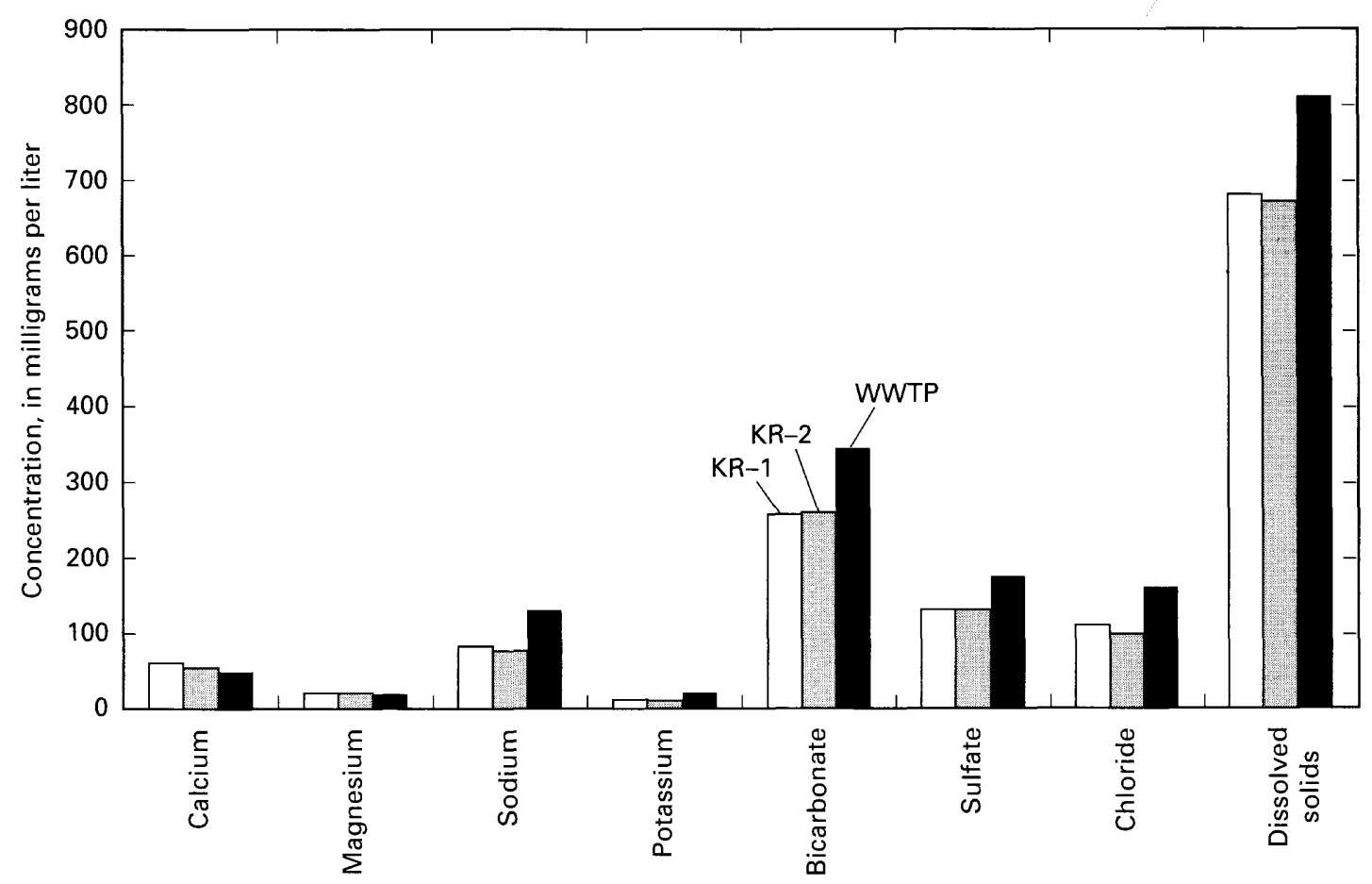

Figure 5. Comparison of median concentrations of major ions and dissolved solids in water from sampling sites KR-1 and KR-2 on the Kansas River and in discharge from the Oakland Wastewater Treatment Plant (sampling site WWTP) in Topeka, Kansas, October 1993-September 1995. Location of sampling sites shown in figure 3.

the other. Therefore, if the reported p-value is less than 0.05 (one-tailed test) or 0.025 (two-tailed test), then $\mathrm{H}_{\mathrm{o}}$ is rejected in favor of $\mathrm{H}_{1}$ (Wonnacott and Wonnacott, 1977). In a one-tailed test, the direction of difference between two populations is indicated by the alternative hypothesis $\left(\mathrm{H}_{1}\right)$. For example, either the central tendency for population $\mathrm{A}$ is larger than that of population B or it is smaller than that of population B. For a two-tailed test, the direction is not indicated, and therefore, $\mathrm{H}_{1}$ becomes a statement that the two populations are just different.

Median concentrations of dissolved solids at sampling sites KR-1 and KR-2 were not significantly different at the 0.05 level of significance ( $p$-value $=0.46$ ). This indicates that, on the basis of samples collected during this study, urbanization between these sampling sites does not generate an identifiable amount of nonpoint-source contamination in regard to dissolved solids. Also, the North Topeka Wastewater Treatment Plant, which discharges into the Kansas River between sampling sites KR-1 and KR-2, has no adverse effects on concentrations of dissolved solids in the Kansas River.

Concentrations of most major ions and dissolved solids were larger in the effluent from the Oakland
Wastewater Treatment Plant (sampling site WWTP) than in water from either Kansas River sampling site. This can be attributed to naturally occurring salts and minerals in human biological waste, salts and minerals introduced into the sanitary-sewer system from residential, commercial, or industrial origins, and from salts and minerals added to the drinking-water supply or wastewater during treatment processes. The Kansas River is used as a water-supply source for the city of Topeka.

Although the median concentration of dissolved solids in water from sampling site WWTP was 21 percent larger than in water from sampling site KR-2 (from data listed in table 11), the effect of discharge from the Oakland Wastewater Treatment Plant on dissolved solids in the Kansas River is minimal because of the large dilution capacity of the Kansas River. On average, the contribution of dissolved solids in discharge from sampling site WWTP increases the median dissolved-solids concentration in water from the Kansas River by $1.0 \mathrm{mg} / \mathrm{L}$, which is equivalent to a 0.15 -percent increase of the median concentration in water from sampling site KR-2. The concentration was calculated using the following equation: 


$$
C=\frac{\left.\left[Q_{1} C_{1}\right)+\left(Q_{2} C_{2}\right)\right]}{\left(Q_{1}+Q_{2}\right)},
$$

where $C$ is median concentration in water from Kansas River after receiving discharge from sampling site WWTP, in milligrams per liter;

$Q_{1}$ is median streamflow at sampling site $\mathrm{KR}-2$, in cubic feet per second;

$C_{1}$ is median concentration of dissolved solids in water from sampling site $\mathrm{KR}-2$, in milligrams per liter;

$Q_{2}$ is median discharge at sampling site WWTP, in cubic feet per second; and

$C_{2}$ is median concentration of dissolved solids in water from sampling site WWTP, in milligrams per liter.

\section{Nutrients}

Nutrients, including compounds of nitrogen and phosphorus, are essential to plant growth. Nitrogen is central to all ecosystems because of its role in the synthesis of protein and, together with carbohydrates and fats, constitutes the major part of living substances (Reid and Wood, 1976). The occurrence of nitrogen in water may be in the form of uncombined elemental nitrogen $\left(\mathrm{N}_{2}\right)$, bound up in organic compounds, or as inorganic compounds such as ammonia, nitrite, and nitrate. In ecological terms, phosphorus is considered the single most critical factor in the maintenance of biochemical cycles. This stems from the fact that phosphorus is necessary to the operation of energy-transfer systems in the cell (Reid and Wood, 1976). In uncontaminated waters, phosphorus normally occurs in relatively small concentrations and establishes the possibility of deficiency of the nutrient. Therefore, in many natural waters, phosphorus may be a limiting factor in primary productivity.

As important as nutrients are in the production and maintenance of healthy ecosystems, excessive concentrations in rivers, lakes, and reservoirs can accelerate the growth of algae and other aquatic plants causing problems such as clogged pipelines, fishkills, and restricted recreation (Litke, 1996). Because of this, the Kansas Department of Health and Environment has established water-quality criteria for certain species of nitrogen and phosphorus. Two sets of $\mathrm{pH}$ - and temperature-dependent criteria (acute and chronic) for total ammonia as nitrogen in water bodies is presented in
Kansas Department of Health and Environment (1994). For the purpose of this report, ammonia as nitrogen concentrations will be compared to the more stringent chronic criterion for total ammonia. Also, the U.S. Environmental Protection Agency (1986) has recommended an instream goal of $0.1 \mathrm{mg} / \mathrm{L}$ for total phosphorus.

Median concentrations of selected nutrient species for water from sampling sites $\mathrm{KR}-1, \mathrm{KR}-2$, and WWTP are presented in table 11 in the "Supplemental Information" section of this report and shown in figure 6 . There is no significant difference in median concentrations of nitrogen species (fig. 6A) or phosphorus species (fig. $6 B$ ) between water from the Kansas River sampling sites (KR-1 and KR-2). Computed p-values for the Wilcoxon two-tailed test were 0.96 for dissolved nitrate as nitrogen, 0.95 for dissolved ammonia as nitrogen, 0.57 for total ammonia plus organic nitrogen as nitrogen, 0.86 for total phosphorus, and 0.98 for dissolved orthophosphate as phosphorus. This indicates that, on the basis of data collected during this study, the urbanized section of Topeka between sampling sites KR-1 and KR-2 does not contribute nutrients from either point or nonpoint sources to an extent that it would increase long-term median concentrations in water from sampling site $\mathrm{KR}-2$ relative to the upstream sampling site (KR-1).

Discharges from the Oakland Wastewater Treatment Plant (sampling site WWTP) contain relatively large concentrations of dissolved ammonia as nitrogen, ammonia plus organic nitrogen as nitrogen, total phosphorus, and dissolved orthophosphate as phosphorus (fig. 6). These discharges may produce substantial increases in Kansas River concentrations. Dissolved ammonia as nitrogen concentrations in water from the Kansas River as a result of discharges from sampling site WWTP were calculated for each water sample collected from sampling site $\mathrm{KR}-2$. Calculations were performed using equation 1 where $Q_{1}$ and $C_{1}$ are streamflow and dissolved ammonia as nitrogen concentrations, respectively, at sampling site $\mathrm{KR}-2$, and $\mathrm{Q}_{2}$ and $\mathrm{C}_{2}$ are discharge and dissolved ammonia as nitrogen concentrations, respectively, in water from sampling site WWTP. Some samples collected at sampling site WWTP were not collected on the same day as those at sampling site KR-2. For the purpose of this analysis, it was assumed that all analytical results from sampling site WWTP were equivalent to sampling on the same day as sampling site KR-2. Results of these 


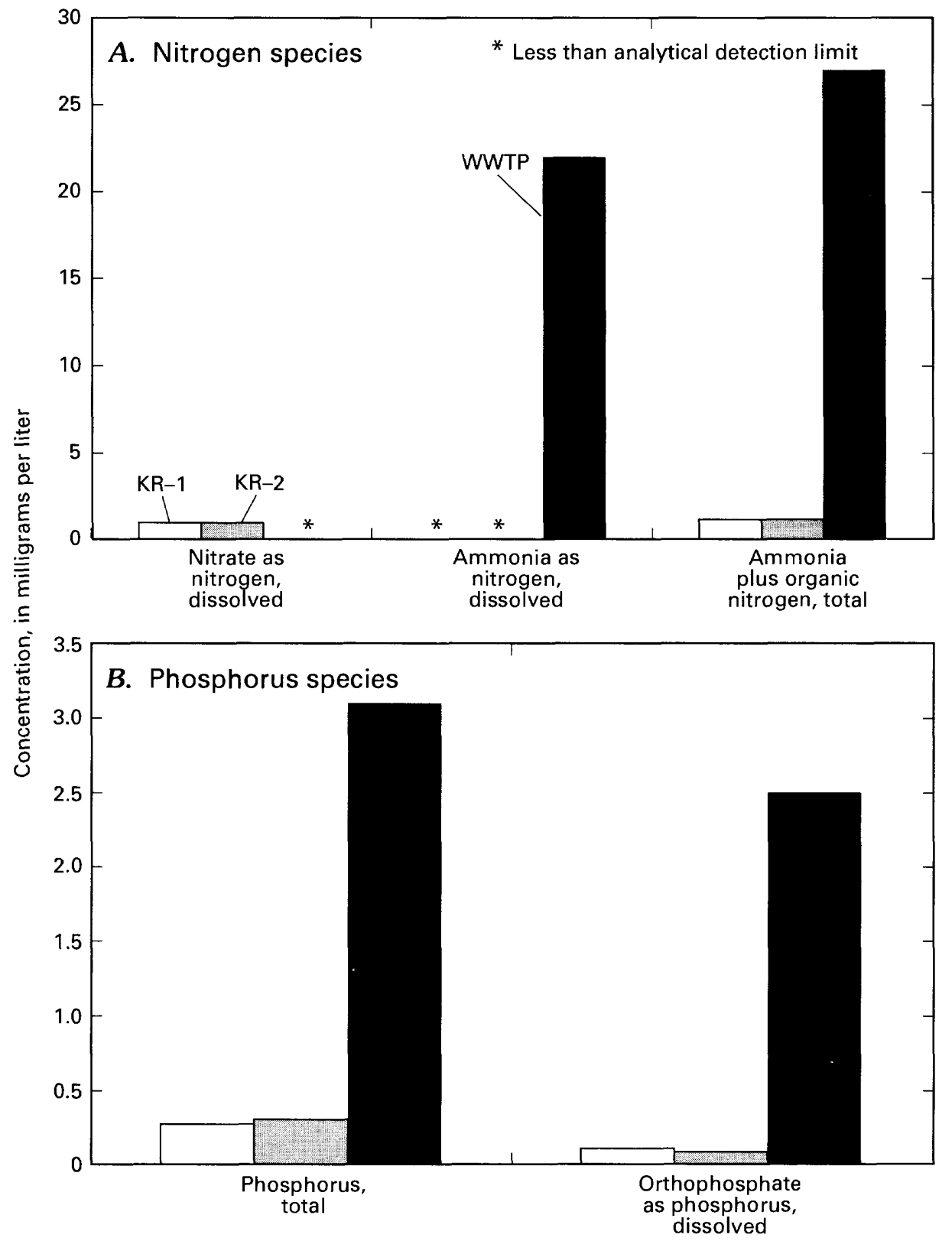

Figure 6. Comparison of median concentrations of selected nutrients in water from sampling sites KR-1 and KR-2 on the Kansas River and in discharge from the Oakland Wastewater Treatment (sampling site WWTP) in Topeka, Kansas, October 1993September 1995. Location of sampling sites shown in figure 3.

calculations are presented in table 6 and shown in figure 7 .

Calculated concentrations of dissolved ammonia as nitrogen in water from the Kansas River after receiving discharge from the Oakland Wastewater Treatment Plant are considerably larger than those in water from sampling site KR-2, upstream from sampling site WWTP (fig. 7). The water-quality implications of this are threefold: (1) ammonia may be toxic to some freshwater invertebrate organisms or fish species (U.S. Environmental Protection Agency, 1986); (2) ammonia is a reduced form of nitrogen, and its subsequent instream oxidation to nitrite and nitrate may cause reductions in dissolved-oxygen concentrations and place stress on aquatic organisms; and (3) nitrate produced through the oxidation of ammonia may accelerate growth of algae and aquatic plants farther downstream. Water-quality criteria for ammonia were

18 Effects of Urbanization on Water Quality in the Kansas River, Shunganunga Creek Basin, and Soldier Creek, Topeka, Kansas, October 1993 Through September 1995 
Table 6. Streamflow, $\mathrm{pH}$, water temperature, and dissolved ammonia as nitrogen concentrations in water samples from the Kansas River (sampling site KR-2) upstream from the Oakland Wastewater Treatment Plant in Topeka, Kansas, discharge and concentrations of dissolved ammonia as nitrogen in water samples from the treatment plant (sampling site WWTP), and calculated concentrations in the Kansas River with discharge from the treatment plant, October 1993-September 1995

[Data on file at U.S.Geological Survey, Lawrence, Kansas; $\mathrm{ft}^{3} / \mathrm{s}$, cubic feet per second; ${ }^{\circ} \mathrm{C}$, degrees Celsius; $\mathrm{mg} / \mathrm{L}$, milligrams per liter; $\mathrm{N}$, nitrogen; $\mathrm{E}$, estimated concentration of a less-than-detection-limit analytical value by using one-half the detection limit rounded to the nearest $0.01 \mathrm{mg} / \mathrm{L} ;--, \mathrm{no}$ data]

\begin{tabular}{|c|c|c|c|c|c|c|c|c|c|}
\hline \multirow[b]{2}{*}{$\begin{array}{l}\text { Date of } \\
\text { sample } \\
\text { (month- } \\
\text { day-year) }\end{array}$} & \multicolumn{4}{|c|}{ Sampling site KR-2 (fig. 3) } & \multicolumn{3}{|c|}{ Sampling site WWTP (fig. 3) } & \multicolumn{2}{|c|}{$\begin{array}{c}\text { Kansas River with } \\
\text { discharge from sampling } \\
\text { site WWTP } \\
\text { (calculated) }\end{array}$} \\
\hline & $\begin{array}{c}\text { Stream- } \\
\text { flow } \\
\left(\mathrm{ft}^{3} / \mathrm{s}\right)\end{array}$ & $\begin{array}{l}\text { pH } \\
\text { (stand- } \\
\text { ard } \\
\text { units }\end{array}$ & $\begin{array}{l}\text { Water } \\
\text { tempera- } \\
\text { ture } \\
\left({ }^{\circ} \mathrm{C}\right)\end{array}$ & $\begin{array}{l}\text { Ammonia } \\
\text { as N, } \\
\text { dissolved } \\
\text { (mg/L) }\end{array}$ & $\begin{array}{l}\text { Date of } \\
\text { sample } \\
\text { (month- } \\
\text { day-year) }\end{array}$ & $\begin{array}{c}\text { Discharge } \\
\left(\mathrm{ft}^{3} / \mathrm{s}\right)\end{array}$ & $\begin{array}{l}\text { Ammonia } \\
\text { as N, } \\
\text { dissolved } \\
\text { (mg/L) }\end{array}$ & $\begin{array}{l}\text { Ammonia } \\
\text { as N, } \\
\text { dissolved } \\
\text { (mg/L) }\end{array}$ & $\begin{array}{c}\text { Chronic } \\
\text { water-quality } \\
\text { criterion for } \\
\text { total ammonia } \\
\text { as } \mathrm{N} \\
\text { concentration }{ }^{1} \\
\text { (mg/L) }\end{array}$ \\
\hline $10-20-93$ & 11,700 & 8.0 & 15.0 & E0.05 & $10-20-93$ & 46 & 26 & 0.15 & 1.27 \\
\hline $11-18-93$ & 10,100 & 8.5 & 8.0 & E.05 & $11-23-93$ & 42 & 33 & .19 & .44 \\
\hline $12-09-93$ & 10,100 & 8.0 & 6.0 & E.05 & $12-09-93$ & 46 & 10 & .10 & 1.36 \\
\hline $01-12-94$ & 7,430 & 7.8 & 1.0 & E.05 & $01-12-94$ & 44 & 29 & .22 & 2.06 \\
\hline $02-15-94$ & 5,500 & 6.9 & 5.0 & E.05 & $02-10-94$ & 43 & 28 & .27 & 2.74 \\
\hline $03-31-94$ & 5,200 & 7.9 & 8.5 & E.05 & 04-05-94 & 40 & 44 & .39 & 1.61 \\
\hline $04-21-94$ & 4,800 & 8.4 & 17.5 & E.05 & $04-21-94$ & 70 & 19 & .32 & .55 \\
\hline $05-12-94$ & 8,880 & 8.3 & 19.5 & -. & $05-12-94$ & 43 & 15 & -- & .67 \\
\hline $06-09-94$ & 11,500 & 7.6 & 19.0 & -- & 06-09-94 & 43 & 22 & -- & 2.37 \\
\hline $06-28-94$ & 6,350 & 8.0 & 26.5 & E.05 & $06-28-94$ & 45 & 18 & .18 & 1.16 \\
\hline 07-19-94 & 4,770 & 8.0 & 27.5 & E.02 & 07-19-94 & 44 & 26 & .26 & 1.10 \\
\hline $08-11-94$ & 4,100 & 8.0 & 26.5 & E.02 & $08-11-94$ & 44 & 20 & .23 & 1.16 \\
\hline $08-31-94$ & 3,250 & 8.1 & 22.0 & E.02 & $08-31-94$ & 44 & 24 & .34 & 1.05 \\
\hline 09-29-94 & 1,090 & 8.1 & 19.0 & -- & 09-29-94 & 41 & 22 & - & 1.05 \\
\hline $10-17-94$ & 1,460 & 7.5 & 18.0 & E.02 & $10-17-94$ & 45 & 37 & 1.1 & 2.71 \\
\hline $11-14-94$ & 1,430 & 8.4 & 11.5 & E.02 & $11-14-94$ & 41 & -- & -- & .55 \\
\hline $12-13-94$ & 3,650 & 8.0 & 2.0 & E.02 & $12-13-94$ & 41 & 22 & .26 & 1.42 \\
\hline $01-12-95$ & 1,890 & 8.0 & 0.0 & E.02 & $01-10-95$ & 44 & 22 & .52 & 1.46 \\
\hline $02-06-95$ & 3,240 & 8.1 & 2.0 & E.02 & $02-06-95$ & 41 & 31 & .41 & 1.18 \\
\hline $03-30-95$ & 4,710 & 8.2 & 8.0 & E.02 & $03-30-95$ & 45 & 30 & .30 & .87 \\
\hline $04-18-95$ & 9,160 & 7.9 & 11.5 & .09 & $04-18-95$ & 55 & 16 & .18 & 1.58 \\
\hline $05-30-95$ & 40,200 & 7.5 & 17.5 & .10 & $05-30-95$ & 87 & -- & -- & 2.72 \\
\hline $06-22-95$ & 41,300 & 7.5 & 23.0 & E.02 & $06-22-95$ & 56 & 8.4 & .03 & 2.71 \\
\hline $07-12-95$ & 12,100 & 7.7 & 28.0 & E.02 & $07-12-95$ & 54 & 12 & .07 & 1.71 \\
\hline $08-15-95$ & 6,790 & 7.9 & 26.0 & E.02 & $08-15-95$ & 49 & 6.3 & .06 & 1.44 \\
\hline $09-12-95$ & 2,700 & 8.3 & 20.5 & E. 02 & $09-12-95$ & 51 & 9.9 & .20 & .67 \\
\hline
\end{tabular}

\footnotetext{
${ }^{1}$ Kansas Department of Health and Environment (1994).
} 


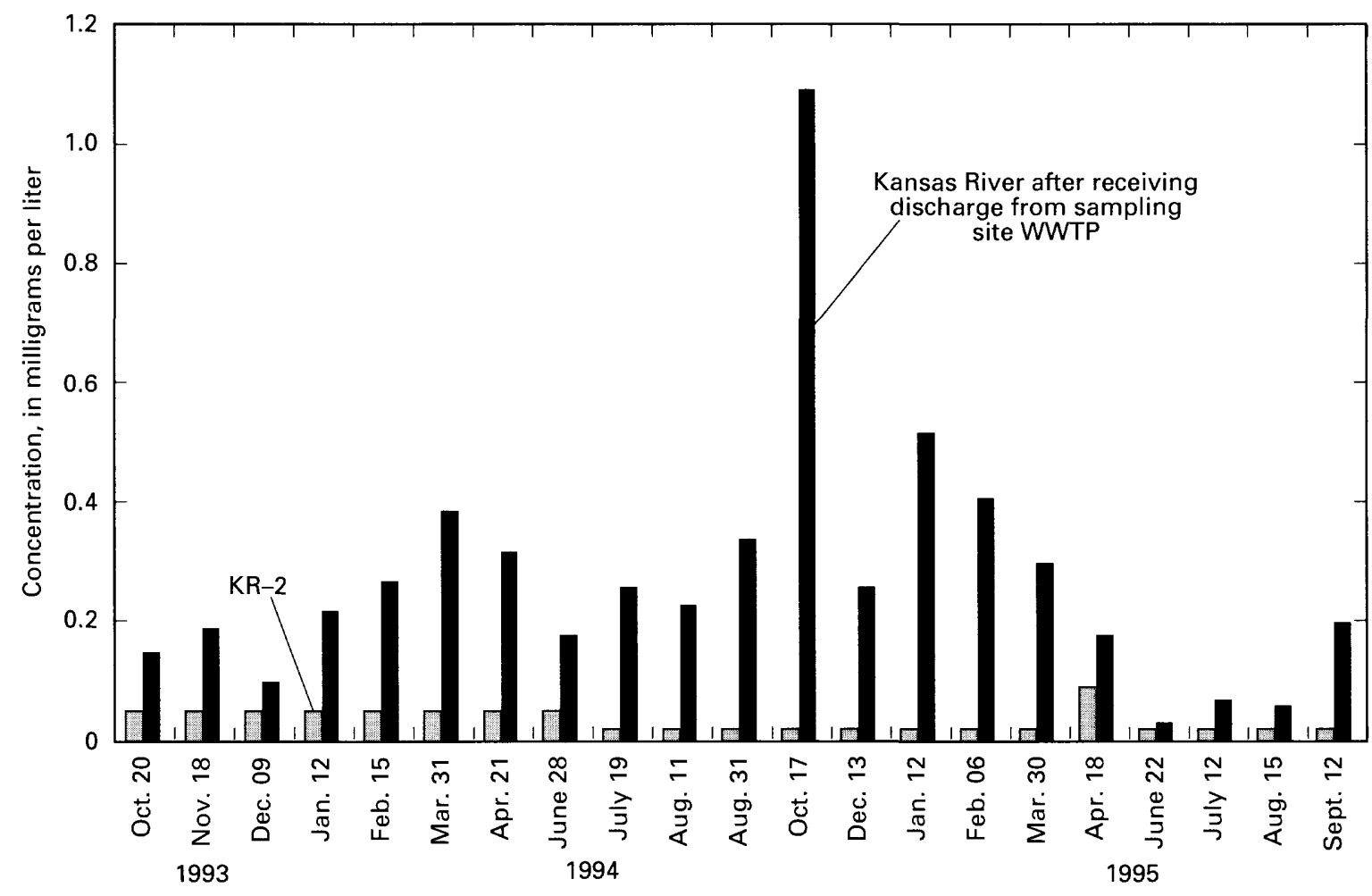

Figure 7. Comparison of dissolved ammonia as nitrogen concentrations in water from Kansas River sampling site K-2 with calculated Kansas River concentrations after receiving discharge from Oakland Wastewater Treatement Plant (sampling site WWTP) in Topeka, Kansas, October 1993-September 1995. Location of sampling sites shown in figure 3 .

calculated from $\mathrm{pH}$ - and temperature-dependent relations presented in Kansas Department of Health and Environment (1994). These calculated values are listed in table 6 . These calculations were based on using 100 percent of the streamflow in the Kansas River for mixing of discharge from sampling site WWTP.

Calculated dissolved ammonia as nitrogen concentrations in water from the Kansas River after receiving discharge from sampling site WWTP as a percentage of the criteria are shown in figure 8 . All but one of the calculated dissolved ammonia as nitrogen concentrations were considerably less than 50 percent of the waterquality criteria, with a median of 20 percent. No calculated concentration exceeded the water-quality criteria. On the basis of data collected during this study, discharges from the Oakland Wastewater Treatment Plant do not result in violations of water-quality criteria for dissolved ammonia as nitrogen in the Kansas River.

Median total phosphorus concentrations were several times larger in discharge from sampling site WWTP than in water from either Kansas River sampling site (fig. $6 B$ ). To determine the effect of discharges from sampling site WWTP on total phosphorus concentrations in water from the Kansas River, calculations similar to those presented for dissolved ammonia as nitrogen concentrations in table 6 were performed. Results of these total phosphorus calculations are listed in table 7.

Generally, discharges from sampling site WWTP produced only small increases in total phosphorus concentrations in water from the Kansas River. Most total phosphorus concentrations in water from the Kansas River ranged from 0.01 to $0.04 \mathrm{mg} / \mathrm{L}$ larger than those concentrations determined in water from sampling site KR-2. The largest increases occurred during periods of relatively small streamflow (less dilution potential) in the Kansas River. Most ( 88 percent) of the total phosphorus concentrations in water from the Kansas River upstream from sampling site WWTP were in excess of the goal of $0.1 \mathrm{mg} / \mathrm{L}$ recommended by the U.S. Environmental Protection Agency (1986). Therefore, small increases resulting from the contribution of discharge from sampling site WWTP had little effect from a water-quality criteria perspective. For data collected during this study, the median increase in total phosphorus concentrations in water from the Kansas 


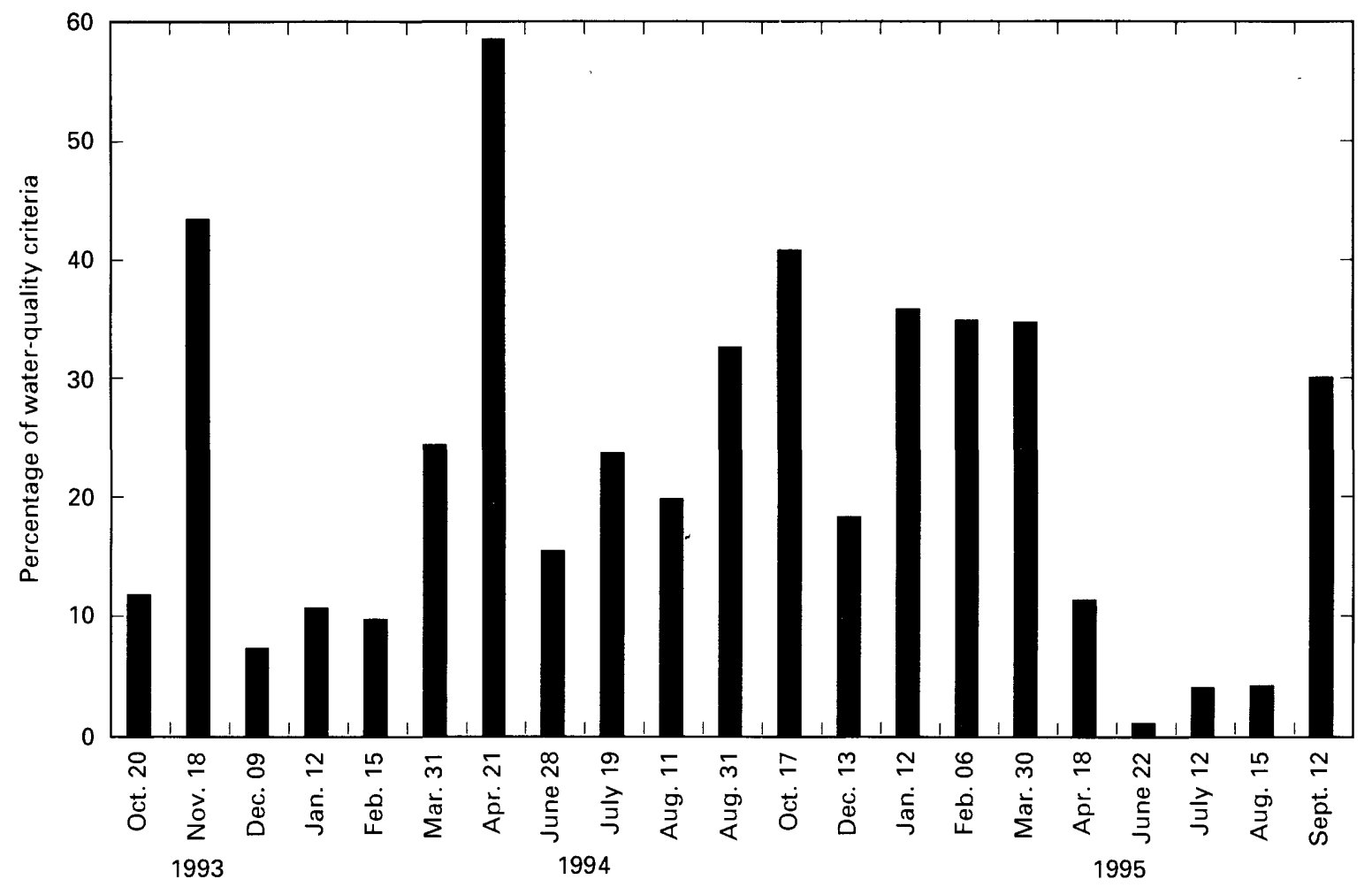

Figure 8. Calculated dissolved ammonia as nitrogen concentrations in water from the Kansas River after receiving discharge from the Oakland Wastewater Treatment Plant (sampling site WWTP) in Topeka, Kansas, as a percentage of water-quality criteria (Kansas Department of Health and Environment, 1994), October 1993-September 1995. Location of sampling site shown in figure 3.

River resulting from discharge from sampling site WWTP was 7.6 percent (calculated from data in table 7) greater than concentrations determined in water from sampling site $\mathrm{KR}-2$.

\section{Bacteria}

The sanitary quality of water and its use as a public-water supply and for recreational activities, such as swimming, wading, boating, and fishing, can be evaluated on the basis of fecal-indicator bacterial densities. Surface water can carry many pathogenic organisms of fecal origin that cause diseases, such as cholera, typhoid fever, dysentery, and other related gastrointestinal disorders (Pope, 1995). Traditionally, sanitary-quality assessments have relied on a membrane-filter procedure for the detection of a group of bacteria (fecal coliform or fecal Streptococcus) common to the intestinal tracts of humans and warmblooded animals. The presence of the measured "fecal-indicator bacteria" denotes contamination by fecal material and the possible presence of pathogenic microorganisms.
The presence of fecal coliforms or fecal Streptococci bacteria in the aquatic environment is an indication of fecal contamination. This contamination may come from municipal wastewater discharges, leachate from domestic septic systems, runoff or ground-water seepage from livestock-producing areas (pastures and confined feedlots), or wildlife populations. These sources indicate that contamination may originate in either the urban or rural (agricultural) environment.

Segfried and others (1984) state that municipal wastewater discharges can have a detrimental effect on the water quality of receiving streams not only in regard to fecal bacteria but also in regard to the introduction of pathogenic organisms, such as reo-, adeno-, and enterovirus; coxsackievirus; and poliovirus. The studies of Stephenson and Street (1978), Doran and others (1981), and Gray and others (1983) have demonstrated the effect of cattle production on fecal coliform densities in runoff from grazed and pastured land and in streams adjacent to these areas.

Median densities of fecal coliform and fecal Streptococci bacteria in water from sampling sites $K R-1$, $\mathrm{KR}-2$, and WWTP are listed in table 11 in the 
Table 7. Streamflow and concentrations of total phosphorus in water samples from the Kansas River (sampling site KR-2) upstream from the Oakland Wastewater Treatment Plant in Topeka, Kansas, discharge and concentrations of total phosphorus in water samples from the treatment plant (sampling site WWTP), and calculated concentrations in the Kansas River with discharge from the treatment plant, October 1993-September 1995

[Data on file at U.S.Geological Survey, Lawrence, Kansas; $\mathrm{ft}^{3} / \mathrm{s}$, cubic feet per second; mg/L, milligrams per liter; --, no data; <, less than]

\begin{tabular}{|c|c|c|c|c|c|c|}
\hline \multicolumn{3}{|c|}{ Sampling site KR-2 (fig. 3) } & \multicolumn{3}{|c|}{ Sampling site WWTP (fig. 3) } & \multirow{2}{*}{ 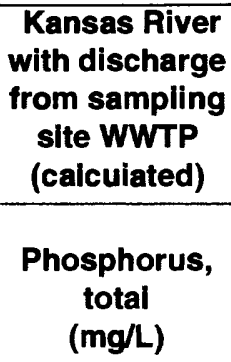 } \\
\hline $\begin{array}{c}\text { Date of } \\
\text { sample } \\
\text { (month-day- } \\
\text { year) }\end{array}$ & $\begin{array}{c}\text { Streamfiow } \\
\left(\mathrm{ft}^{3} / \mathrm{s}\right)\end{array}$ & $\begin{array}{c}\text { Phosphorus, } \\
\text { total } \\
\text { (mg/L) }\end{array}$ & $\begin{array}{c}\text { Date of } \\
\text { sample } \\
\text { (month-day- } \\
\text { year) }\end{array}$ & $\begin{array}{c}\text { Discharge } \\
\left(\mathrm{ft}^{3} / \mathrm{s}\right)\end{array}$ & $\begin{array}{c}\text { Phosphorus, } \\
\text { total } \\
\text { (mg/L) }\end{array}$ & \\
\hline $10-20-93$ & 11,700 & 0.40 & $10-20-93$ & 46 & 2.9 & 0.41 \\
\hline $11-18-93$ & 10,100 & .50 & $11-23-93$ & 42 & 4.3 & .52 \\
\hline $12-09-93$ & 10,100 & .40 & $12-09-93$ & 46 & 3.9 & .42 \\
\hline $01-12-94$ & 7,430 & .24 & $01-12-94$ & 44 & 3.5 & .26 \\
\hline $02-15-94$ & 5,500 & .23 & $02-10-94$ & 43 & 3.3 & .25 \\
\hline $03-31-94$ & 5,200 & .03 & $04-05-94$ & 40 & 2.8 & .05 \\
\hline $04-21-94$ & 4,800 & .29 & $04-21-94$ & 70 & 2.1 & .31 \\
\hline $05-12-94$ & 8,880 & .27 & $05-12-94$ & 43 & 2.6 & .28 \\
\hline 06-09-94 & 11,500 & - & 06-09-94 & 43 & 2.4 & -- \\
\hline $06-28-94$ & 6,350 & .32 & $06-28-94$ & 45 & 2.8 & .34 \\
\hline $07-19-94$ & 4,770 & .34 & 07-19-94 & 44 & 3.7 & .37 \\
\hline $08-11-94$ & 4,100 & .27 & 08-11-94 & 44 & 3.6 & .31 \\
\hline $08-31-94$ & 3,250 & .58 & $08-31-94$ & 44 & 3.3 & .62 \\
\hline 09-29-94 & 1,090 & .02 & 09-29-94 & 41 & 3.4 & .14 \\
\hline $10-17-94$ & 1,460 & ${ }^{1}<.02$ & $10-17-94$ & 45 & 4.5 & .14 \\
\hline $11-14-94$ & 1,430 & .21 & $11-14-94$ & 41 & 4.6 & .33 \\
\hline $12-13-94$ & 3,650 & .23 & $12-13-94$ & 41 & 2.4 & .25 \\
\hline $01-12-95$ & 1,890 & .14 & 01-10-95 & 44 & 4.1 & .23 \\
\hline $02-06-95$ & 3,240 & .22 & $02-06-95$ & 41 & 3.2 & .26 \\
\hline $03-30-95$ & 4,710 & .34 & 03-30-95 & 45 & 3.1 & .37 \\
\hline $04-18-95$ & 9,160 & .90 & 04-18-95 & 55 & 2.6 & .91 \\
\hline $05-30-95$ & 40,200 & .87 & 05-30-95 & 87 & 1.9 & .87 \\
\hline $06-22-95$ & 41,300 & .43 & $06-22-95$ & 56 & 2.2 & .43 \\
\hline $07-12-95$ & 12,100 & .44 & $07-12-95$ & 54 & 2.8 & .45 \\
\hline $08-15-95$ & 6,790 & .56 & $08-15-95$ & 49 & 1.4 & .57 \\
\hline $09-12-95$ & 2,700 & .30 & $09-12-95$ & 51 & 3.1 & .35 \\
\hline
\end{tabular}

${ }^{1}$ For calculation purposes, a concentration of $0.01 \mathrm{mg} / \mathrm{L}$ was assumed. 
"Supplemental Information" section of this report and shown in figure 9. Median densities of fecal coliform bacteria were less in water from the downstream Kansas River sampling site $(K R-2)$ than in water from the upstream sampling site (KR-1), whereas the inverse situation was documented for fecal Streptococci.

Because of the nature and origin of both fecal groups, it was expected that median densities in water from sampling site KR-2 would be either smaller or larger than in water from sampling site KR-1. Two possible explanations for the apparent contradiction presented in figure 9 are: (1) point and nonpoint sources of fecal bacteria from the urbanized section of Topeka between sampling sites KR-1 and KR-2 result in little change in fecal coliform but a substantial percentage change in median densities of fecal Streptococci bacteria; or

(2) the urbanization between sampling sites KR-1 and KR-2 has little effect on median bacterial densities, and the observed differences are the result of relatively small densities and of variations in the proportion of the fecal groups, temporal variation, and variation within and between sampling sites. It is believed that the second possible explanation would account for the differences shown in figure 9. This belief was tested using a two-tailed Wilcoxon rank-sum test at a significance level of 0.05 . Results of this test indicated no significant difference between sampling sites KR-1 and KR-2 for either fecal coliform bacteria densities ( $\mathrm{p}$-value $=0.95$ ) or fecal Streptococci bacteria densities (p-value $=0.14)$.

The major effect of urbanization on bacterial densities in water from the Kansas River was the result of discharge from the Oakland Wastewater Treatment Plant (sampling site WWTP). As indicated in figure 9, median densities of both fecal coliform and fecal Streptococci bacteria in discharge at sampling site WWTP are several orders of magnitude larger than densities in water from the Kansas River. To quantify the effect of this discharge, calculations similar to those for ammonia and phosphorus concentrations presented in tables 6 and 7, respectively, were performed for the fecal groups. Results of these calculations are listed in table 8 and shown in figure 10. Densities in water from the Kansas River resulting from discharge from

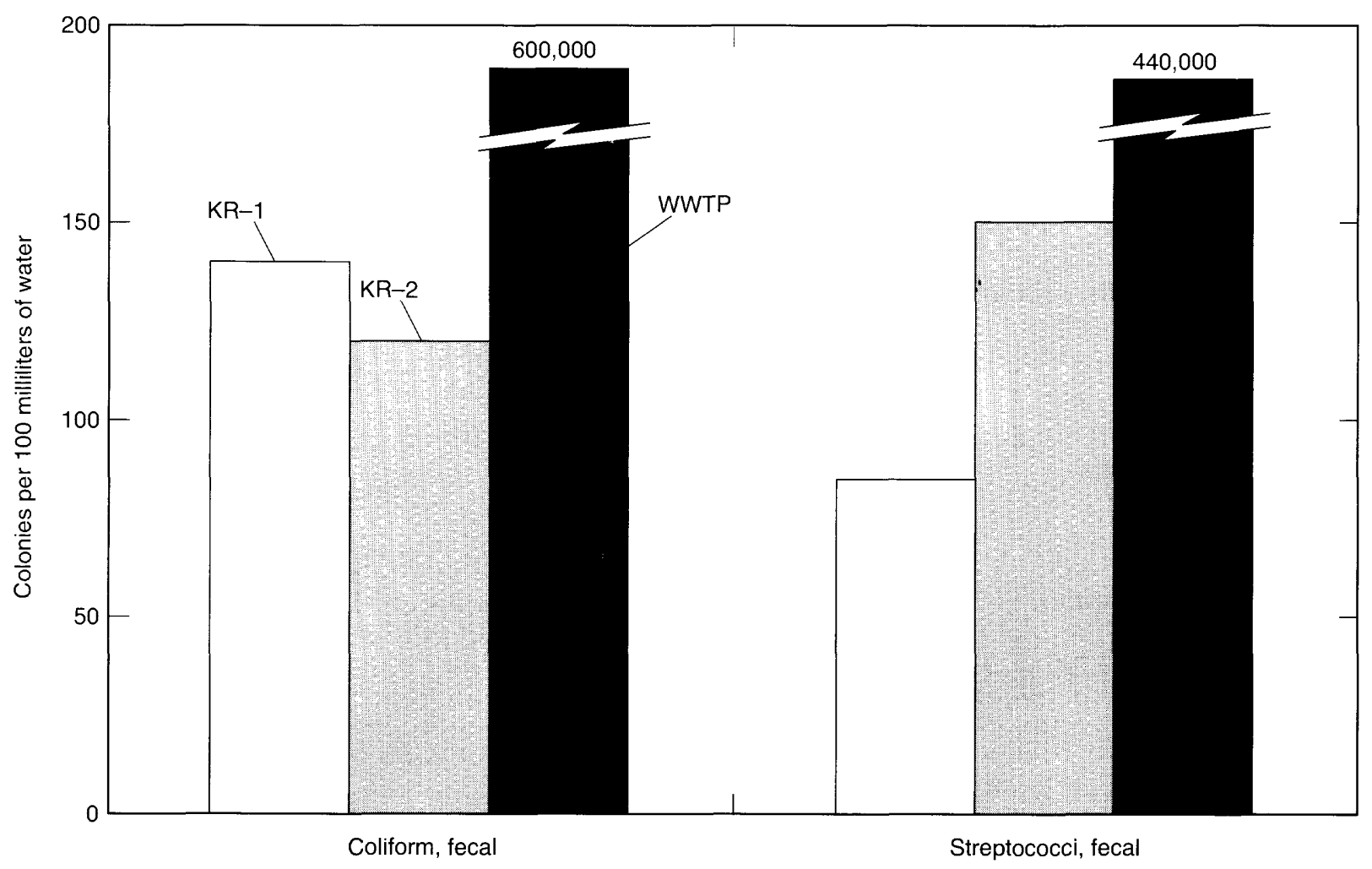

Figure 9. Comparison of median densities of fecal coliform and fecal Streptococci bacteria in water from sampling sites KR-1 and KR-2 on the Kansas River and in discharge from the Oakland Wastewater Treatment Plant (sampling site WWTP) in Topeka, Kansas, October 1993-September 1995. Location of sampling sites shown in figure 3 . 
Table 8. Streamflow and bacterial densities in water samples from the Kansas River (sampling site KR-2) upstream from the Oakland Wastewater Treatment Plant in Topeka, Kansas, discharge and bacterial densities in water samples from the treatment plant (sampling site WWTP), and calculated densities in the Kansas River with discharge from the treatment plant, October 1993-September 1995

[Data on file at U.S.Geological Survey, Lawrence, Kansas; $\mathrm{ft}^{3} / \mathrm{s}$, cubic feet per second; cols $/ 100 \mathrm{~mL}$, colonies per 100 milliliters of water; --, no data; $<$, less than]

\begin{tabular}{|c|c|c|c|c|c|c|c|c|c|}
\hline \multicolumn{4}{|c|}{ Sampling site KR-2 (fig. 3) } & \multicolumn{4}{|c|}{ Sampling site WWTP (fig. 3) } & \multicolumn{2}{|c|}{$\begin{array}{l}\text { Kansas River with } \\
\text { discharge from } \\
\text { sampling site WWTP } \\
\text { (calculated) }\end{array}$} \\
\hline $\begin{array}{l}\text { Date of } \\
\text { sample } \\
\text { (month- } \\
\text { day-year) }\end{array}$ & $\begin{array}{c}\text { Stream- } \\
\text { flow } \\
\left(\mathrm{ft}^{3} / \mathrm{s}\right)\end{array}$ & $\begin{array}{l}\text { Fecal } \\
\text { coliform } \\
\text { density } \\
\text { (cols/100 } \\
\mathrm{mL})\end{array}$ & $\begin{array}{c}\text { Fecal } \\
\text { Strepto- } \\
\text { cocci } \\
\text { density } \\
\text { (cols/100 } \\
\mathrm{mL})\end{array}$ & $\begin{array}{l}\text { Date of } \\
\text { sample } \\
\text { (month- } \\
\text { day-year) }\end{array}$ & $\begin{array}{c}\text { Discharge } \\
\left(\mathrm{ft}^{3} / \mathbf{s}\right)\end{array}$ & $\begin{array}{c}\text { Fecal coliform } \\
\text { density } \\
\text { (cols } / 100 \mathrm{~mL} \text { ) }\end{array}$ & $\begin{array}{c}\text { Fecal } \\
\text { Streptococci } \\
\text { density } \\
\text { (cols } / 100 \mathrm{~mL} \text { ) }\end{array}$ & $\begin{array}{l}\text { Fecal } \\
\text { coliform } \\
\text { density } \\
\text { (cols/100 } \\
\mathrm{mL})\end{array}$ & $\begin{array}{c}\text { Fecal } \\
\text { Strepto- } \\
\text { cocci } \\
\text { density } \\
\text { (cols } / 100 \\
\mathrm{~mL})\end{array}$ \\
\hline $10-20-93$ & 11,700 & 500 & 3,000 & $10-20-93$ & 46 & $1,800,000$ & $1,000,000$ & 7,500 & 6,900 \\
\hline $11-18-93$ & 10,100 & 65 & 150 & $11-23-93$ & 42 & -- & $7,600,000$ & -- & 32,000 \\
\hline $12-09-93$ & 10,100 & 120 & 240 & $12-09-93$ & 46 & 780,000 & 220,000 & 3,700 & 1,200 \\
\hline $01-12-94$ & 7,430 & 80 & 20 & $01-12-94$ & 44 & 670,00 & 240,000 & 4,000 & 1,400 \\
\hline $02-15-94$ & 5,500 & 70 & 40 & $02-10-94$ & 43 & 350,000 & 280,000 & 2,800 & 2,200 \\
\hline $03-31-94$ & 5,200 & 5 & $<1$ & $04-05-94$ & 40 & 68,000 & -- & 520 & -- \\
\hline $04-21-94$ & 4,800 & 50 & 130 & $04-21-94$ & 70 & -- & $3,100,000$ & -- & 45,000 \\
\hline $05-12-94$ & 8,880 & 66 & -- & $05-12-94$ & 43 & 990,000 & -- & 4,800 & -- \\
\hline 06-09-94 & 11,500 & 40,000 & 53,000 & $06-09-94$ & 43 & 840,000 & 640,000 & 43,000 & 55,000 \\
\hline 06-28-94 & 6,350 & 210 & 150 & $06-28-94$ & 45 & $7,200,000$ & 70,000 & 51,000 & 640 \\
\hline 07-19-94 & 4,770 & 500 & $<1$ & $07-19-94$ & 44 & -- & $46,000,000$ & - & $1_{420,000}$ \\
\hline 08-11-94 & 4,100 & 110 & 640 & $08-11-94$ & 44 & $4,100,000$ & -- & 44,000 & -- \\
\hline $08-31-94$ & 3,250 & 4,900 & 7,500 & $08-31-94$ & 44 & 570,000 & $2,700,000$ & 12,000 & 43,000 \\
\hline 09-29-94 & 1,090 & 37 & 270 & 09-29-94 & 41 & 210,000 & -- & 7,600 & $\cdots$ \\
\hline $10-17-94$ & 1,460 & 220 & 900 & $10-17-94$ & 45 & 900,000 & $1,100,000$ & 27,000 & 34,000 \\
\hline $11-14-94$ & 1,430 & 40 & 63 & $11-14-94$ & 41 & $1,000,000$ & $32,000,000$ & 28,000 & 890,000 \\
\hline $12-13-94$ & 3,650 & 150 & 130 & $12-13-94$ & 41 & 430,000 & 34,000 & 4,900 & 510 \\
\hline $01-12-95$ & 1,890 & 5 & 200 & 01-10-95 & 44 & 680,000 & 330,000 & 15,000 & 7,700 \\
\hline $02-06-95$ & 3,240 & 10 & 130 & $02-06-95$ & 41 & 450,000 & 150,000 & 5,600 & 2,000 \\
\hline $03-30-95$ & 4,710 & 120 & 95 & $03-30-95$ & 45 & 23,000 & 180,000 & 340 & 1,800 \\
\hline $04-18-95$ & 9,160 & 27,000 & 56,000 & 04-18-95 & 55 & 380,000 & 250,000 & 29,000 & 57,000 \\
\hline $05-30-95$ & 40,200 & 600 & 2,300 & $05-30-95$ & 87 & 320,000 & 45,000 & 1,300 & 2,400 \\
\hline $06-22-95$ & 41,300 & 68 & 110 & $06-22-95$ & 56 & $1,300,000$ & 650,000 & 1,800 & 990 \\
\hline $07-12-95$ & 12,100 & 250 & 150 & $07-12-95$ & 54 & 600,000 & 540,000 & 2,900 & 2,500 \\
\hline $08-15-95$ & 6,790 & 170 & 600 & $08-15-95$ & 49 & 510,000 & $4,700,000$ & 3,800 & 34,000 \\
\hline $09-12-95$ & 2,700 & 200 & 180 & $09-12-95$ & 51 & 250,000 & 29,000 & 4.800 & 710 \\
\hline
\end{tabular}

\footnotetext{
${ }^{1}$ Calculated using only density at sampling site WWTP.
}

24 Effects of Urbanization on Water Quality in the Kansas River, Shunganunga Creek Basin, and Soldier Creek, Topeka, Kansas, October 1993 Through September 1995 

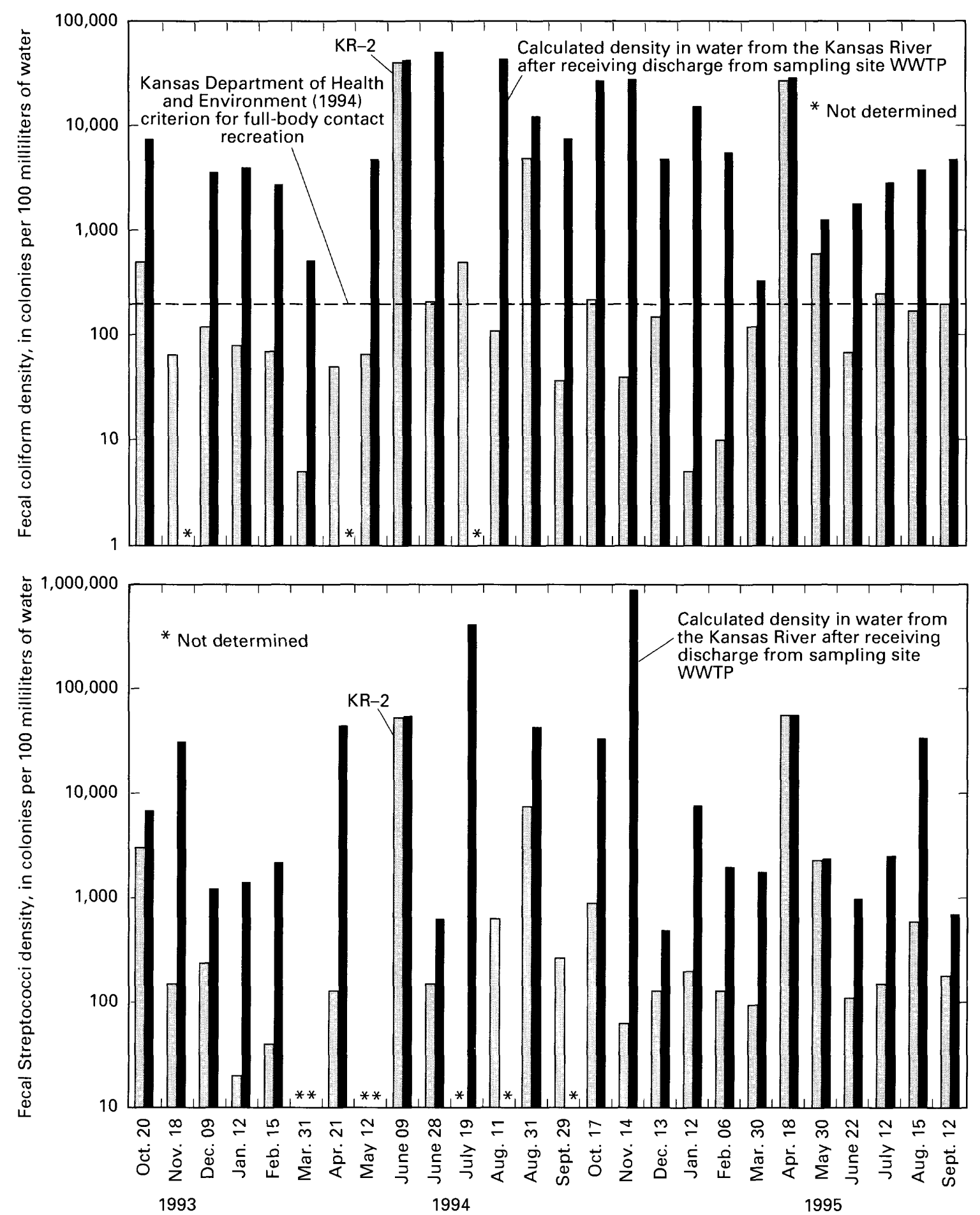

Figure 10. Comparison of densities of fecal coliform and fecal Streptococci bacteria in water from Kansas River sampling site KR-2 with calculated Kansas River densities after receiving discharge from the Oakland Wastewater Treatment Plant (sampling site WWTP) in Topeka, Kansas, October 1993-September 1995. Location of sampling sites shown in figure 3. 
sampling site WWTP were calculated using equation 1 where $\mathrm{Q}_{1}$ and $\mathrm{C}_{1}$ are streamflow $\left(\mathrm{ft}^{3} / \mathrm{s}\right)$ and density (cols/100 $\mathrm{mL}$ of water), respectively, at sampling site $\mathrm{KR}-2$, and $\mathrm{Q}_{2}$ and $\mathrm{C}_{2}$ are discharged and density, respectively, at sampling site WWTP.

Calculated fecal coliform densities in water from the Kansas River resulting from discharge from sampling site WWTP ranged from 340 to 51,000 cols/ $100 \mathrm{~mL}$ of water (table 8). All 23 (100 percent) of those calculated densities exceeded the $200 \mathrm{cols} / 100 \mathrm{~mL}$ of water criterion established by the Kansas Department of Health and Environment (1994) for full-body contact recreation. This range contrasts with the 5 to $40,000 \mathrm{cols} / 100 \mathrm{~mL}$ of water fecal coliform range in water from sampling site $\mathrm{KR}-2$ where nine samples (35 percent) exceeded $200 \mathrm{cols} / 100 \mathrm{~mL}$ of water criterion. Median fecal coliform densities in water from the Kansas River increased from 120 cols $/ 100 \mathrm{~mL}$ of water at sampling site KR-2 to 4,900 cols $/ 100 \mathrm{~mL}$ of water after receiving discharge from sampling site WWTP.

Results of calculated densities of fecal Streptococci bacteria in water from the Kansas River resulting from discharge from sampling site WWTP were similar to those of fecal coliform. Calculated densities ranged from 510 to $890,000 \mathrm{cols} / 100 \mathrm{~mL}$ of water (table 8). Median densities increased from $150 \mathrm{cols} / 100 \mathrm{~mL}$ of water at sampling site KR-2 to 4,700 cols $/ 100 \mathrm{~mL}$ of water after receiving discharge from sampling site WWTP.

The calculated results listed in table 8 and shown in figure 10 were computed using 100 percent of Kansas River streamflow and assumed no instantaneous "die-off" of bacteria. However, bacterial die-off probably begins immediately upon discharge from sampling site WWTP and theoretically continues until extinction in the Kansas River some distance downstream. The exact length of the Kansas River affected by bacterial densities in excess of water-quality criteria is not known. Bacterial die-off rates are dependent on many factors such as streamflow, $\mathrm{pH}$, water temperature, turbidity, intensity of sunlight, and concentrations of chemicals that may be toxic to fecal bacteria.

\section{Metals and Trace Elements}

Metals and trace elements normally occur in natural water in small concentrations even though some are naturally abundant. For instance, iron and aluminum represent the first and third, respectively, most abundant trace elements in the Earth's outer crust (Hem, 1985). The natural occurrence of metals and trace elements in stream water is the result of dissolution of rock minerals containing these elements. However, urbanization and associated manufacturing and support industries can be a source of substantial quantities of some metals and trace elements. For example, aluminum, iron, and zinc are used extensively in the construction of buildings, exterior structures and trim work, in automobiles, and as protective coverings or coatings against corrosion and oxidation of framework or base metals. Chromium, copper, and nickel, similarly, are used throughout the urban environment as protective coatings or as structural, roofing, or decorative components of exterior structures. Lead, once a component of gasoline, was widely dispersed in the environment until its gradual phaseout beginning in the early 1970's. Large amounts of lead also are released in the smelting of ores and burning of coal (Hem, 1985).

Median total recoverable concentrations of selected metals and trace elements in water from sampling sites on the Kansas River (sampling sites KR-1 and $K R-2$ ) and in discharge from the Oakland Wastewater Treatment Plant (sampling site WWTP) are listed in table 11 in the "Supplemental Information" section of this report and shown in figure 11. Generally, median total recoverable concentrations of most metals and trace elements varied little between sampling sites KR-1 and KR-2 and, in fact, no significant differences (at 0.05 level of significance) between sampling sites $\mathrm{KR}-1$ and $\mathrm{KR}-2$ were indicated by Wilcoxon rank-sum tests (table 9) for those constituents shown in figure 11. The results in table 9 indicate that, on the basis of the current data set, the urbanized section of Topeka between sampling sites KR-1 and KR-2 has no detrimental effect on water quality in the Kansas River with regard to the median total concentrations of metals and trace elements shown.

Median total recoverable concentrations of metals and trace elements (fig. 11) in water from sampling site WWTP were less than median total recoverable concentrations in water from either Kansas River sampling site with the exception of total recoverable molybdenum and zinc. Median total recoverable concentrations of these two elements in discharge from the treatment plant were larger than in water from either Kansas River sampling site and may suggest that urban-related processes are responsible for these larger concentrations. However, because of small discharge at sampling site WWTP relative to Kansas River streamflow, the effect of sampling site WWTP on median total 


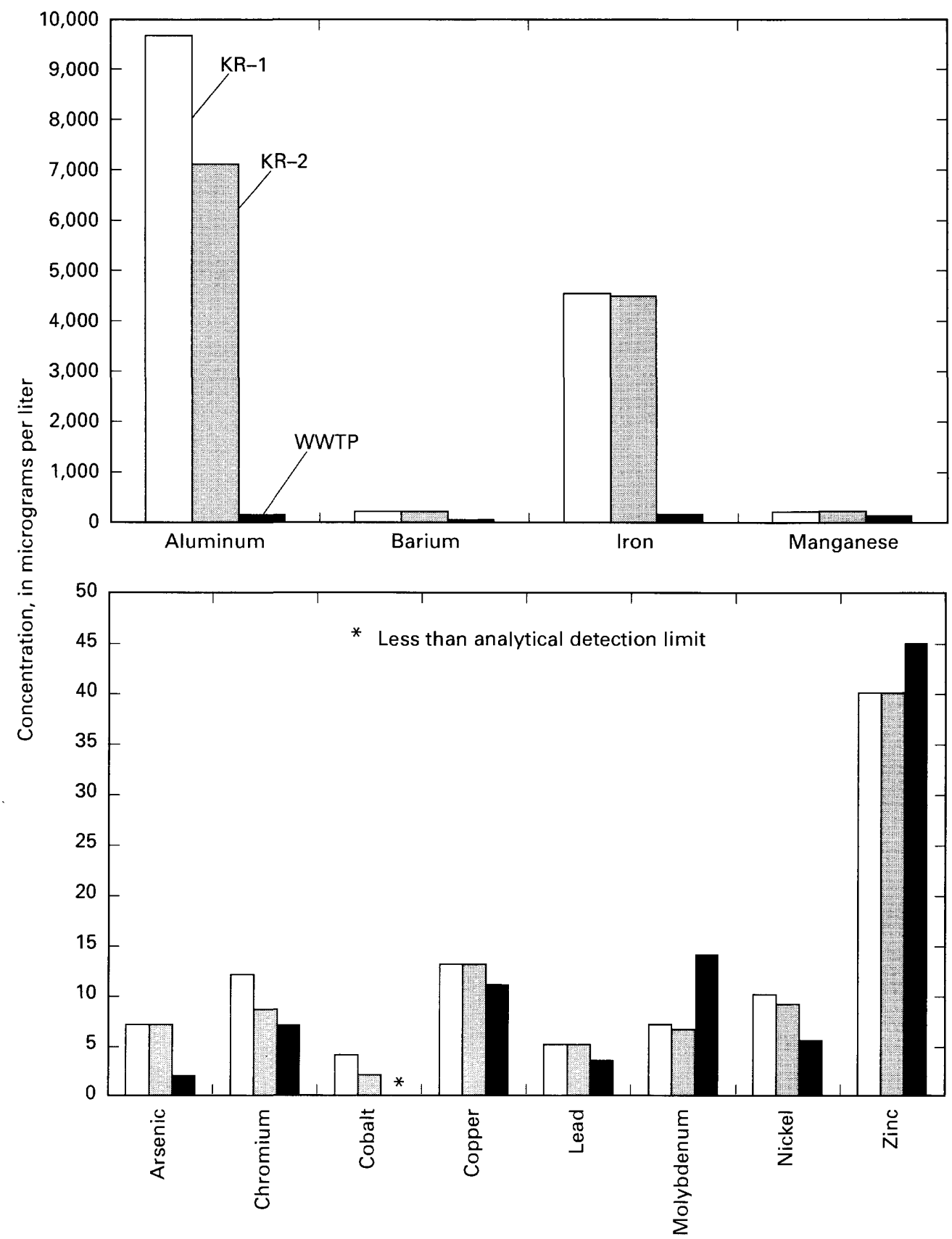

Figure 11. Comparison of median total recoverable concentrations of selected metals and trace elements in water from sampling sites KR-1 and KR-2 on the Kansas River and in discharge from the Oakland Wastewater Treatment Plant (sampling site WWTP) in Topeka, Kansas, October 1993-September 1995. Location of sampling sites shown in figure 3.

recoverable concentrations of molybdenum and zinc in water from the Kansas River is considered negligible.

\section{Pesticides}

Pesticides are a general classification of synthetic organic compounds that are used to control the growth or occurrence of undesirable plants (herbicides) or insects (insecticides). These include organic compounds containing nitrogen, chlorine, or phosphorus. The occurrence of these compounds in natural water is indicative of contamination from human-related sources. Both the agricultural and urban communities 
Table 9. Probability values ( $p$-values) calculated by the Wilcoxon rank-sum test comparing total recoverable concentrations of selected metals and trace elements between Kansas River sampling sites KR-1 and KR-2 in Topeka, Kansas

[At a significance level of 0.05 , p-values greater than 0.025 for a two-tailed test indicate no significant difference in concentrations between sampling sites]

\begin{tabular}{cccccccccccc}
\hline $\begin{array}{c}\text { Alumi- } \\
\text { num }\end{array}$ & Arsenic & Barium & $\begin{array}{c}\text { Chro- } \\
\text { mium }\end{array}$ & Cobalt & Copper & Iron & Lead & $\begin{array}{c}\text { Man- } \\
\text { ganese }\end{array}$ & $\begin{array}{c}\text { Moly- } \\
\text { bdenum }\end{array}$ & Nickel & Zinc \\
\hline 0.73 & 0.88 & 0.80 & 0.57 & 0.56 & 0.92 & 0.96 & 0.81 & 0.99 & 0.18 & 0.75 & 0.86 \\
\hline
\end{tabular}

use pesticides, although not necessarily the same compounds.

Analytical results for samples of water collected at sampling sites KR-1, KR-2, and WWTP for pesticide analyses are included in table 11 in the "Supplemental Information" section of this report. Too few samples were collected to develop specific conclusions concerning pesticide occurrences; however, some generalizations can be made. Concentrations of agricultural herbicides or metabolites were detected in water from both Kansas River sampling sites (KR-1 and KR-2). These included acetochlor, alachlor, atrazine, cyanazine, deethylatrazine, EPTC, metolachlor, metribuzin, prometon, simazine, and tebuthiuron. Also, the insecticides carburyl and carbofuran were detected in water from the Kansas River. Most of these herbicides are used in the production of corn, grain sorghum, and soybeans. Several of these herbicides also were detected in discharge at sampling site WWTP including alachlor, atrazine, metolachlor, and prometon. The fact that these herbicides were detected in wastewater discharge indicates that the drinking-water treatment process does not completely remove herbicides from the source water (Kansas River). Generally, concentrations of herbicides in discharge at sampling site WWTP were about one-half the concentration in water from the Kansas River.

Additional pesticides were detected in discharge from sampling site WWTP that were not detected in water from the Kansas River. These included the herbicide linuron and insecticides chlorpyrifos, Diazinon, and malathion. All three insecticides commonly are used around homes and businesses to control termites, white grubs, ants, and other insects in lawns, gardens, and ornamental plantings. The occurrence of these insecticides in wastewater discharge suggest residential or commercial disposal in the sanitary-sewer system or input by way of a combined storm/sanitary sewer system. No concentrations of pesticides in either the Kansas River or wastewater discharge were greater than established Kansas Department of Health and Environment (1994) water-quality criteria.

\section{Shunganunga Creek Basin}

Three sampling sites were established in the Shunganunga Creek Basin to evaluate potential effects from urbanization (fig. 3 and table 1). Two sampling sites were located on the main stem of Shunganunga Creek (sampling sites $\mathrm{SH}-1$ and $\mathrm{SH}-2$ ) and one sampling site on South Branch Shunganunga Creek (sampling site SB-1), a major tributary to Shunganunga Creek. A statistical summary of concentrations of selected water-quality constituents in water from sampling sites $\mathrm{SH}-1, \mathrm{SH}-2$, and SB-1 is presented in table 11 in the "Supplemental Information" section of this report.

\section{Major lons and Dissolved Solids}

A comparison of median concentrations of major ions and dissolved solids in water from sampling sites in the Shunganunga Creek Basin is presented in figure 12. Median concentrations of dissolved solids were not significantly different (at the 0.05 level of significance) among the three sampling sites in the Shunganunga Creek Basin. Results of Wilcoxon rank-sum, two-tailed tests indicated a p-value of 0.21 for an evaluation of sampling sites $\mathrm{SH}-1$ and $\mathrm{SH}-2$ and p-values of 0.45 and 0.53 for an evaluation of sampling sites $\mathrm{SH}-1$ and $\mathrm{SB}-1$ and $\mathrm{SB}-1$ and $\mathrm{SH}-2$, respectively. These results indicate that, on the basis of current data set, the sections of Topeka between sampling sites $\mathrm{SH}-1$ and $\mathrm{SH}-2$ and upstream from sampling site SB-1 are not a significant source of instream concentrations of major ions and dissolved solids, at least when evaluated from a long-term perspective ( 2 years).

Sampling sites $\mathrm{SH}-1, \mathrm{SB}-1$, and $\mathrm{SH}-2$ also were sampled during a previous water-quality investigation conducted from October 1979 through September 1981 (Pope and Bevans, 1987). A comparison of median 


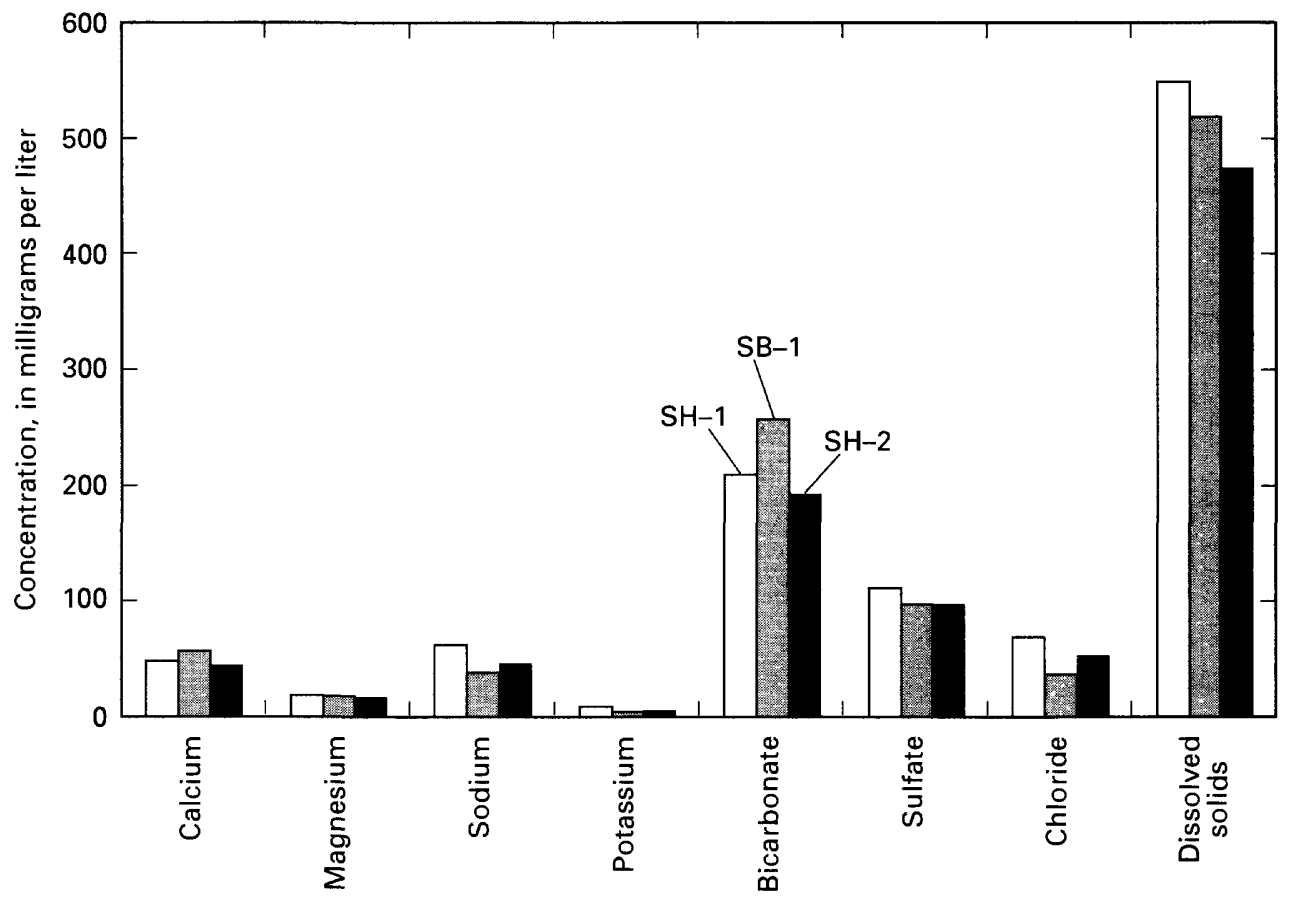

Figure 12. Comparison of median concentrations of major ions and dissolved solids in water from sampling sites $\mathrm{SH}-1, \mathrm{SB}-1$, and $\mathrm{SH}-2$ in the Shunganunga Creek Basin, Topeka, Kansas, October 1993-September 1995. Location of sampling sites shown in figure 3.

concentrations of dissolved solids in dry-weather streamflow documented in the current study (1993-95) with those from the previous study is shown in figure 13. Dry-weather streamflow is streamflow resulting from a combination of base flow and point-source discharges and is not affected by storm runoff. Because the current data set contains a few samples of storm runoff at each sampling site, the current data set was censored to contain only samples reflective of streamflow ranges equivalent to those of the previous study. During the 1979-81 study, the maximum streamflows for dry-weather samples collected at sampling sites $\mathrm{SH}-1, \mathrm{SB}-1$, and $\mathrm{SH}-2$ were $18.0,9.2$, and $15.0 \mathrm{ft}^{3} / \mathrm{s}$, respectively; therefore, for this current study, only those samples with streamflow less than or equal to those maximums were used for comparative analysis. This produced sample populations of 21,21 , and 18 , respectively, at the three sampling sites. The number of dissolved-solids analyses of water from sampling sites $\mathrm{SH}-1, \mathrm{SB}-1$, and $\mathrm{SH}-2$ performed during the 1979-81 study were 10,9 , and 10 , respectively (Pope and others, 1983).

The median concentration of dissolved solids documented in the current study (1993-95) in water from sampling site $\mathrm{SH}-1$ for dry-weather streamflow samples $(547 \mathrm{mg} / \mathrm{L})$ was 48 percent larger than the median concentration reported from the 1979-81 study. This increase was determined to be statistically significant (at the 0.05 level of significance) on the basis of a one-tailed, Wilcoxon rank-sum test with a $\mathrm{p}$-value of 0.0019 . This increase probably is the result of the construction of the Sherwood Lake Wastewater Treatment Plant during the 1980's to meet the needs of increased urbanization around and downstream from Sherwood Lake. As was previously shown (fig. 5) in the Kansas River discussion, discharge from wastewater-treatment plants may contain dissolved-solids concentrations larger than water in the receiving streams. During the 1979-81 study, two small "package" wastewater-treatment plants were operated between Sherwood Lake and sampling site $\mathrm{SH}-1$, neither of which had substantial discharge. Discharge from one plant was measured at $0.04 \mathrm{ft}^{3} / \mathrm{s}(0.026 \mathrm{Mgal} / \mathrm{d})$. This previous discharge compares to the normal operating discharge of $0.5 \mathrm{Mgal} / \mathrm{d}$ from the current Sherwood Lake plant. Additionally, because of greater urbanization upstream from sampling site $\mathrm{SH}-1$, dissolved solids may be affected by greater road deicing application during 1993-95 than was the case during 1979-81. Subsequent runoff of deicing salt (sodium chloride) may be partly responsible for the larger median 


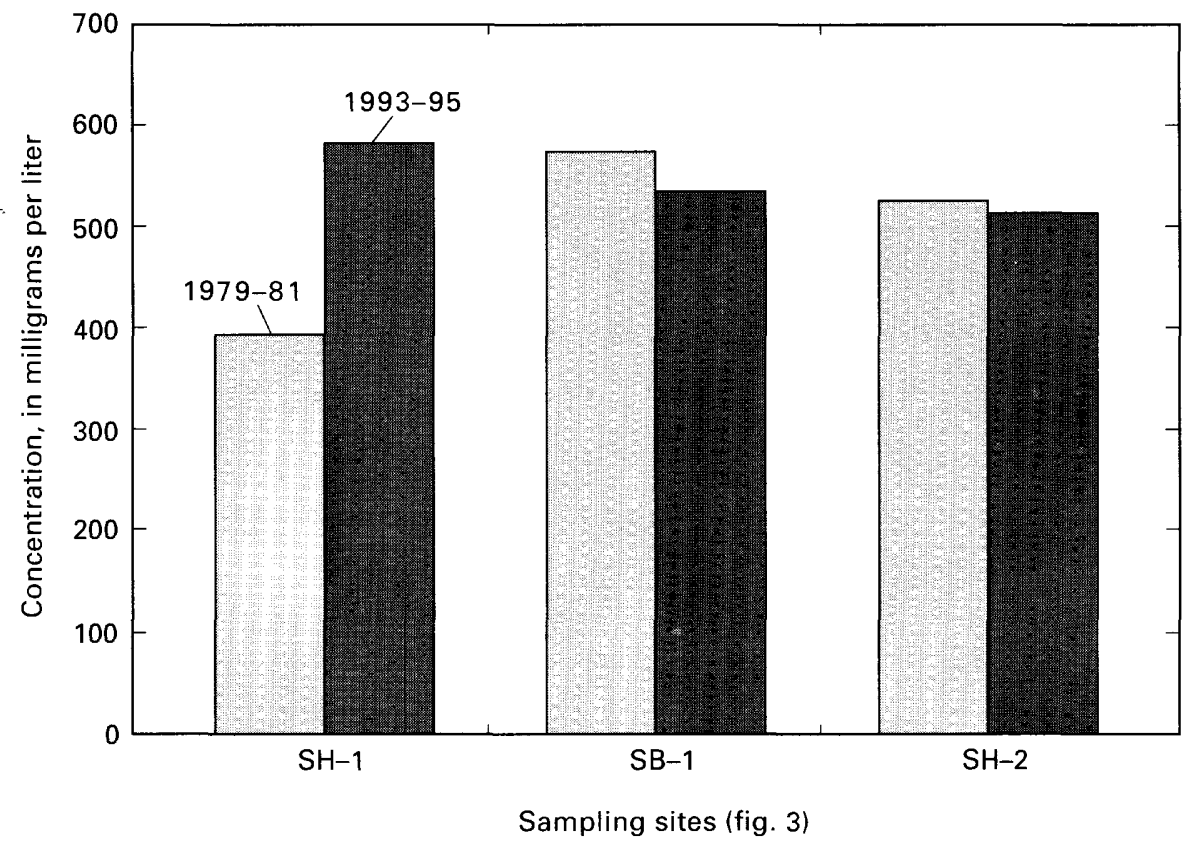

Figure 13. Comparison of median concentrations of dissolved solids in dry-weather streamflow from October 1979 through September 1981 (Pope and Bevans, 1987) with median concentrations from October 1993 through September 1995 in water from sampling sites $\mathrm{SH}-1, \mathrm{SB}-1$, and $\mathrm{SH}-2$ in Shunganunga Creek Basin, Topeka, Kansas.

dissolved-solids concentration documented during the current study.

Median concentrations of dissolved solids in water from sampling sites SB-1 and SH-2 were 7 and 2 percent less, respectively, during 1993-95 than reported for 1979-81 (fig. 13). However, these differences between the two time periods were not statistically significant (at the 0.05 level of significance) at either sampling site. Wilcoxon one-tailed, rank-sum tests calculated p-values of 0.45 at sampling site SB-1 and 0.41 at sampling site $\mathrm{SH}-2$. Therefore, although a statistically significant increase in median dissolvedsolids concentration in dry-weather streamflow was documented in water from the upstream reach of Shunganunga Creek (sampling site $\mathrm{SH}-1$ ), no significant change has been documented in median dissolvedsolids concentration from the entire basin between 1979-81 and 1993-95.

\section{Nutrients}

The median concentration of dissolved nitrate as nitrogen in water from sampling site $\mathrm{SH}-1$ was 5.7 and 4.2 times larger than in water from sampling sites SB-1 and $\mathrm{SH}-2$, respectively (fig. 14). These differences were significant at the 0.05 level of significance as indi- cated by Wilcoxon rank-sum, one-tailed p-values of less than 0.0001 for both sites. This larger median concentration in water from sampling site $\mathrm{SH}-1$ is probably the result of discharge from the Sherwood Lake Wastewater Treatment Plant upstream from sampling site SH-1. However, median concentrations of dissolved ammonia as nitrogen were less than $0.1 \mathrm{mg} / \mathrm{L}$ (analytical detection limit) in water from all three sampling sites. These small concentrations of dissolved ammonia in water from the main stem of Shunganunga Creek are probably the result of nitrification (oxidation of ammonia to nitrate) of wastewater prior to its discharge from the Sherwood Lake Wastewater Treatment Plant and because of a lack of additional sources of nutrients (municipal and industrial) between sampling sites $\mathrm{SH}-1$ and $\mathrm{SH}-2$.

The median concentration of total ammonia plus organic nitrogen as nitrogen was largest in water from the downstream-most sampling site SH-2 (fig. 14); however, this difference, relative to sampling site sites SH-1, was not statistically significant at the 0.05 level of significance as determined by a Wilcoxon rank-sum, one-tailed p-value of 0.16 . The median concentration of total ammonia plus organic nitrogen as nitrogen at sampling site $\mathrm{SB}-1$ was significantly (0.05 level of significance) smaller than median 

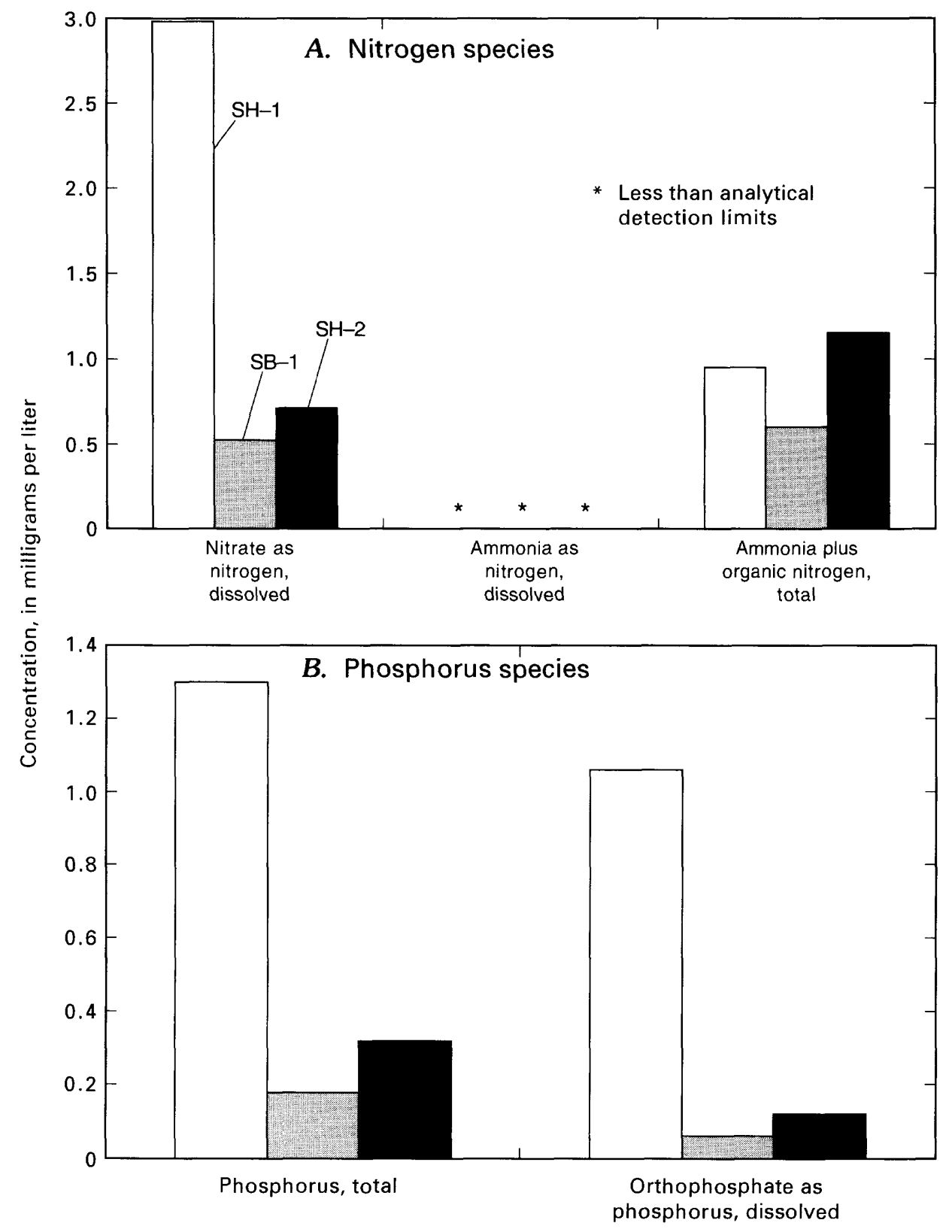

Figure 14. Comparison of median concentrations of selected nutrients in water from sampling sites $\mathrm{SH}-1, \mathrm{SB}-1$, and $\mathrm{SH}-2$ in the Shunganunga Creek Basin, Topeka, Kansas, October 1993-September 1995. Location of sampling sites shown in figure 3.

concentrations at either sampling sites $\mathrm{SH}-1$ or $\mathrm{SH}-2$ (one-tailed p-values of 0.01 and 0.003 , respectively). This difference between tributary sampling site SB-1 and main-stem Shunganunga Creek sampling sites SH-1 and SH-2 probably reflects differences in wastewater discharges within the subbasins. Sampling sites $\mathrm{SH}-1$ and $\mathrm{SH}-2$ are affected by discharge from the Sherwood Lake Wastewater Treatment Plant, whereas, during this study, there were no wastewater discharges in the South Branch Shunganunga Creek subbasin (upstream from sampling site SB-1).

Median concentrations of total phosphorus and dissolved orthophosphate as phosphorus in water from sampling site SH-1 were considerably larger than in water from the other two sampling sites (fig. 14). Median concentrations of total phosphorus were 7.2 and 4.1 times larger in water from sampling site $\mathrm{SH}-1$ than in water from sampling sites SB-1 and $\mathrm{SH}-2$, respectively. Median concentrations of dissolved 
orthophosphate were 18 and 8.8 times larger in water from sampling site $\mathrm{SH}-1$ than in water from sampling sites SB-1 and SH-2, respectively. These differences in median concentrations of total phosphorus and dissolved orthophosphate were significant at the 0.05 level of significance as indicated by Wilcoxon rank-sum, one-tailed p-values of less than 0.0001 for all comparisons. These large between-site differences in phosphorus species reflect the effect of discharge from the Sherwood Lake Wastewater Treatment Plant. From a water-quality criteria perspective, median concentrations of total phosphorus in water from all three sampling sites in the Shunganunga Creek Basin were larger than the U.S. Environmental Protection Agency (1986) recommended goal of $0.1 \mathrm{mg} / \mathrm{L}$. Although wastewater discharge is probably responsible for median concentrations of total phosphorus in water from the main stem of Shunganunga Creek exceeding the recommended goal, the $0.18-\mathrm{mg} / \mathrm{L}$ median concentration of total phosphorus in water from sampling site SB-1 is probably of nonpoint-source, agricultural

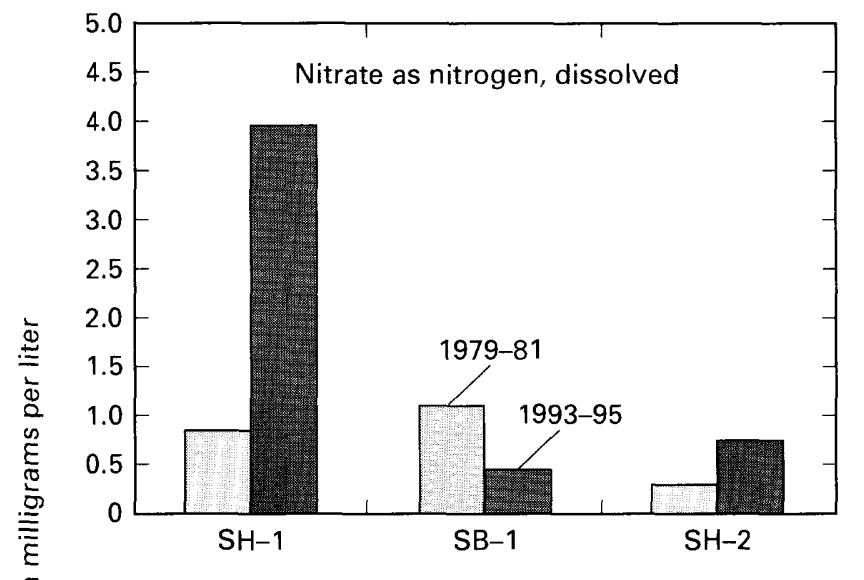

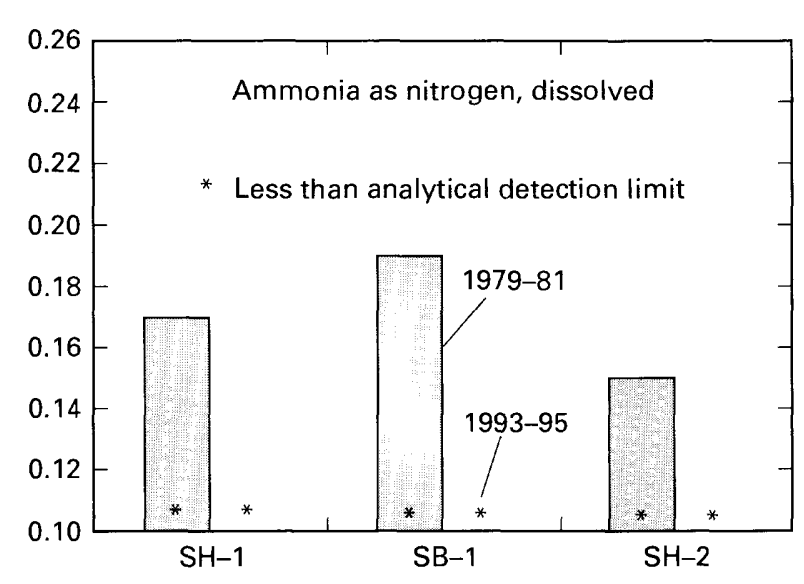

origin, considering the current absence of municipal wastewater discharge. The large differences in median concentrations of phosphorus species between main-stem Shunganunga Creek sampling sites SH-1 and $\mathrm{SH}-2$ are probably the result of in-channel deposition of total phosphorus and oxidation to orthophosphate and utilization of orthophosphate by phytoplankton and aquatic vegetation between the two sites.

Comparison of median concentrations of selected nutrients in dry-weather streamflow from sampling sites in the Shunganunga Creek Basin from October 1993 through September 1995 with median concentrations in samples collected from October 1979 through September 1981 are shown in figure 15. The median concentration of dissolved nitrate as nitrogen was 4.7 times larger during 1993-95 than during 1979-81 in water from sampling site $\mathrm{SH}-1$. This increase was significant at the 0.05 level as indicated by a Wilcoxon rank-sum, one-tailed p-value of 0.001 and probably reflects the greater wastewater discharge upstream from sampling site SH-1 during 1993-95

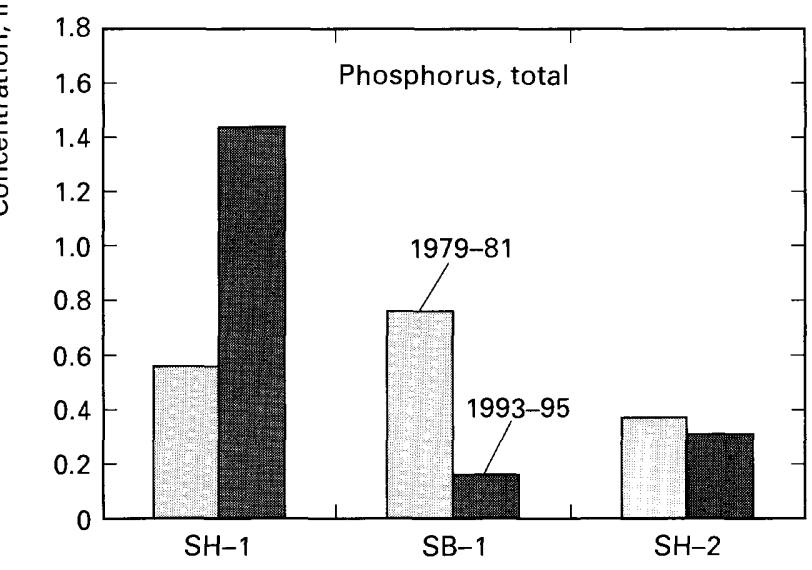

Figure 15. Comparison of median concentrations of selected nutrients in dry-weather streamflow from October 1979 through September 1981 (Pope and Bevans, 1987) with median concentrations from October 1993 through September 1995 in water from sampling sites $\mathrm{SH}-1, \mathrm{SB}-1$, and $\mathrm{SH}-2$ in the Shunganunga Creek Basin, Topeka, Kansas. 
than during 1979-81. In contrast, the median concentration of dissolved nitrate as nitrogen in water from sampling site SB-1 was 59 percent less during 1993-95 than that documented during 1979-81. This decrease was significant at the 0.05 level as indicated by a Wilcoxon rank-sum, one-tailed p-value of 0.007 and probably is the result of no current wastewater discharges in the South Branch Shunganunga Creek subbasin, whereas during the earlier study, two small wastewater-treatment plants were in operation in this subbasin.

The median concentration of dissolved nitrate in water from sampling site $\mathrm{SH}-2$ was 2.5 times larger during 1993-95 than during 1979-81; however, the increase was not significant at the 0.05 level as indicated by a Wilcoxon rank-sum, one-tailed p-value of 0.20 . Although median concentrations at selected sampling sites in the Shunganunga Creek Basin were significantly different between the two studies, the basin as a whole displayed no significant change even though there appears to be an upward trend on the main stem Shunganunga Creek. This perceived trend is the result of the expansion of wastewater-treatment facilities upstream from sampling site $\mathrm{SH}-1$ between the 1979-81 and 1993-95 Shunganunga Creek studies and indicates an effect of past management decisions.

Median concentrations of dissolved ammonia as nitrogen were less than $0.10 \mathrm{mg} / \mathrm{L}$ (analytical detection limit) in water from all three sampling sites in the Shunganunga Creek Basin during 1993-95 compared to an average median concentration of $0.17 \mathrm{mg} / \mathrm{L}$ in water from the three sampling sites during 1979-81. These reductions in median concentrations are significant at the 0.05 level for all three sampling sites as indicated by Wilcoxon rank-sum, one-tailed p-values ranging from less than 0.001 to 0.015 . The decrease documented in the current study is probably the result of the oxidation of ammonia prior to discharge from the Sherwood Lake Wastewater Treatment Plant and the removal of two small wastewater-treatment plants in the South Branch Shunganunga Creek subbasin between studies and indicates an effect of past management decisions. During the earlier study, the two small wastewater-treatment plants, then in operation upstream from sampling site $\mathrm{SH}-1$, were not capable of converting ammonia to nitrate.

Comparative results of median concentrations of total phosphorus between the previous and current study were similar to those for dissolved nitrate as nitrogen. The median concentration in water from sam- pling site SH-1 was 2.6 times larger during 1993-95 than during 1979-81, whereas in water from sampling site SB-1 the median concentration during 1993-95 was 78 percent less than during the 1979-81 study. These differences at sampling sites SH-1 and SB-1 were both significant at the 0.05 level as indicated by Wilcoxon rank-sum, one-tailed p-values of 0.002 and less than 0.001 , respectively. Median concentrations of total phosphorus at sampling site SH-2 were not significantly different (at the 0.05 level) between the previous and current study. In general, nutrient concentrations in Shunganunga Creek during dry-weather streamflow are of point-source origin and predominately from discharge from the Sherwood Lake Wastewater Treatment Plant.

\section{Bacteria}

Median densities of fecal coliform and fecal Streptococci bacteria were largest in water from the upstream-most Shunganunga Creek sampling site (SH-1) and smallest in water from the downstream-most sampling site (SH-2) (fig. 16). This, much like median nutrient concentrations, appears to indicate point-source contamination, possibly from the Sherwood Lake Wastewater Treatment Plant. However, effluent from the Sherwood Lake Wastewater Treatment Plant is chlorinated (disinfected) before discharge to Shunganunga Creek (Edie Snethen, Director of Public Works, city of Topeka, oral commun., 1996). Therefore, the densities indicated in figure 16 probably represent nonpoint-source contributions from wildlife and livestock. The median density of fecal coliform bacteria was substantially greater than the 200 cols $/ 100$ $\mathrm{mL}$ of water criterion for full-body contact recreation established by the Kansas Department of Health and Environment (1994) in water from sampling site $\mathrm{SH}-1$ and less than that in water from sampling sites SB-1 and $\mathrm{SH}-2$.

\section{Metals and Trace Elements}

Median concentrations of total recoverable metals and trace elements varied between sampling sites in the Shunganunga Creek Basin (fig. 17). Wilcoxon rank-sum, two-tailed tests were conducted on metal and trace-element concentrations in water from the three sampling sites in the Shunganunga Creek Basin to determine if these variations between sampling sites were statistically significant at the 0.05 level. Results of these Wilcoxon rank-sum tests are presented in table 10. 


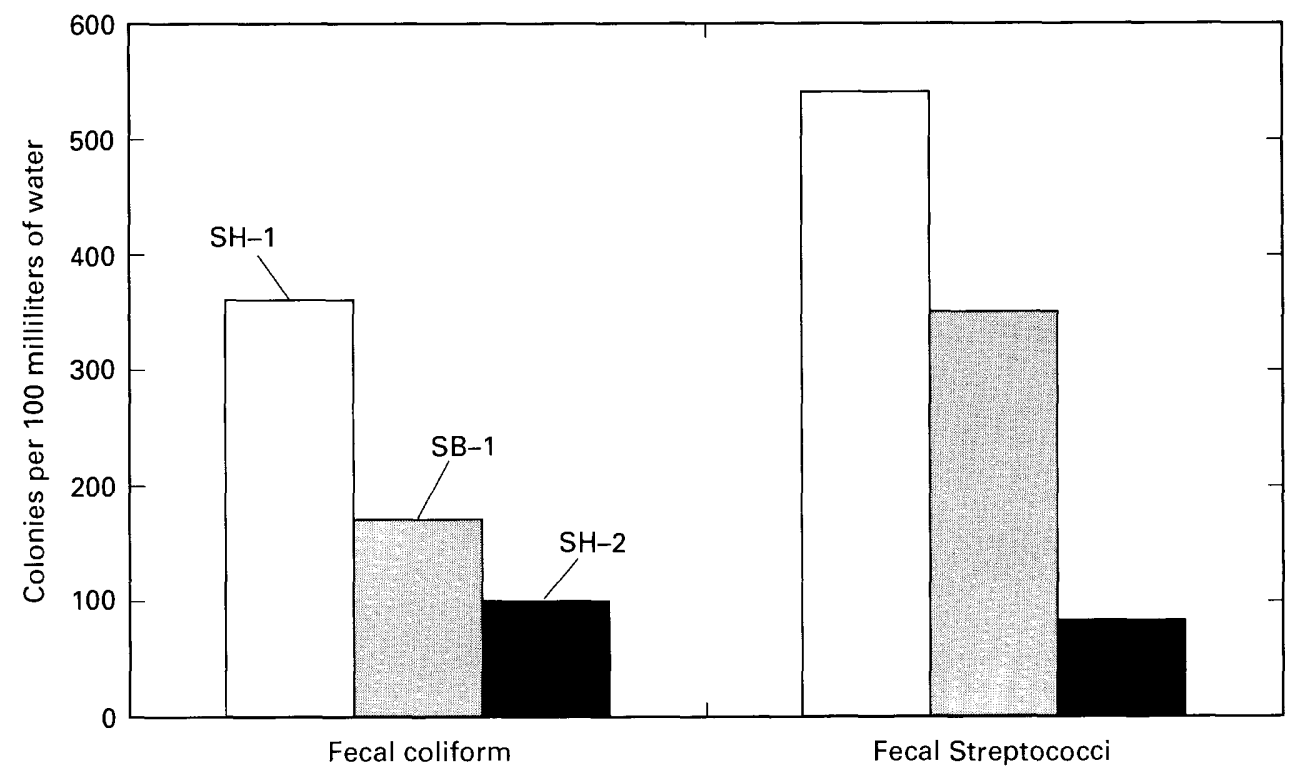

Figure 16. Comparison of median densities of fecal coliform and fecal Streptococci bacteria in water from sampling sites $\mathrm{SH}-1, \mathrm{SB}-1$, and $\mathrm{SH}-2$ in the Shunganunga Creek Basin, Topeka, Kansas, October 1993-September 1995. Location of sampling sites shown in figure 3 .

There were no significant differences in median concentrations of any of the constituents shown in figure 17 between sampling sites $\mathrm{SH}-1$ and SB-1. This probably indicates that the processes responsible for the occurrence of metals and trace elements or the degree to which these processes function are not substantially different between the subbasins upstream from sampling sites $\mathrm{SH}-1$ and SB-1. In contrast, median concentrations of four constituents shown in figure 17 were significantly different between upstream and downstream sampling sites on the main stem Shunganunga Creek, sites SH-1 and $\mathrm{SH}-2$, respectively. Median concentrations of total recoverable aluminum, iron, manganese, and molybdenum were significantly larger in water from sampling site $\mathrm{SH}-2$ than in water from the upstream sampling site $\mathrm{SH}-1$. Median concentrations of total recoverable aluminum and iron were about three times larger in water from sampling site $\mathrm{SH}-2$ than in water from sampling site $\mathrm{SH}-1$. Similarly, the median concentration of total recoverable manganese was 26 percent larger in water from sampling site $\mathrm{SH}-2$ than in water from sampling site $\mathrm{SH}-1$, and the median concentration of total recoverable molybdenum was twice as large in water from sampling site $\mathrm{SH}-2$ than in water from sampling site $\mathrm{SH}-1$.

The larger median concentrations of aluminum, iron, manganese, and molybdenum at sampling site SH-2 probably are the result of their widespread use in the urban environment. Aluminum and iron are used extensively in automobiles and many exterior applications from small ornamental items to large structural components. Manganese is used in metal alloys, dry-cell batteries, micronutrient fertilizer additives, organic compounds used in paint driers, and as chemical reagents (U.S. Environmental Protection Agency, 1986). Molybdenum is used as an alloy in steel, in welding rods, as a lubricant additive, and in ceramics (Hem, 1985).

The median concentration of total recoverable iron in water from sampling site $\mathrm{SH}-2$ is about 50 percent larger than the $1,000-\mu \mathrm{g} / \mathrm{L}$ freshwater water-quality criterion for total recoverable iron (U.S. Environmental Protection Agency, 1986). Therefore, urbanization between sampling sites $\mathrm{SH}-1$ and $\mathrm{SH}-2$ appears to have a detrimental effect on total recoverable iron concentrations in water from Shunganunga Creek.

Although, median concentrations of total recoverable aluminum and iron in water from sampling site $\mathrm{SH}-2$ are large relative to the other Shunganunga Creek sampling sites, median concentrations of total recoverable aluminum and iron were at least 7,000 and $4,400 \mu \mathrm{g} / \mathrm{L}$, respectively, in water from the Kansas River sampling sites (KR-1 and KR-2). Discharge of Shunganunga Creek into the Kansas River probably would have no detrimental effect on median concentrations of metals and trace elements in the Kansas River. 

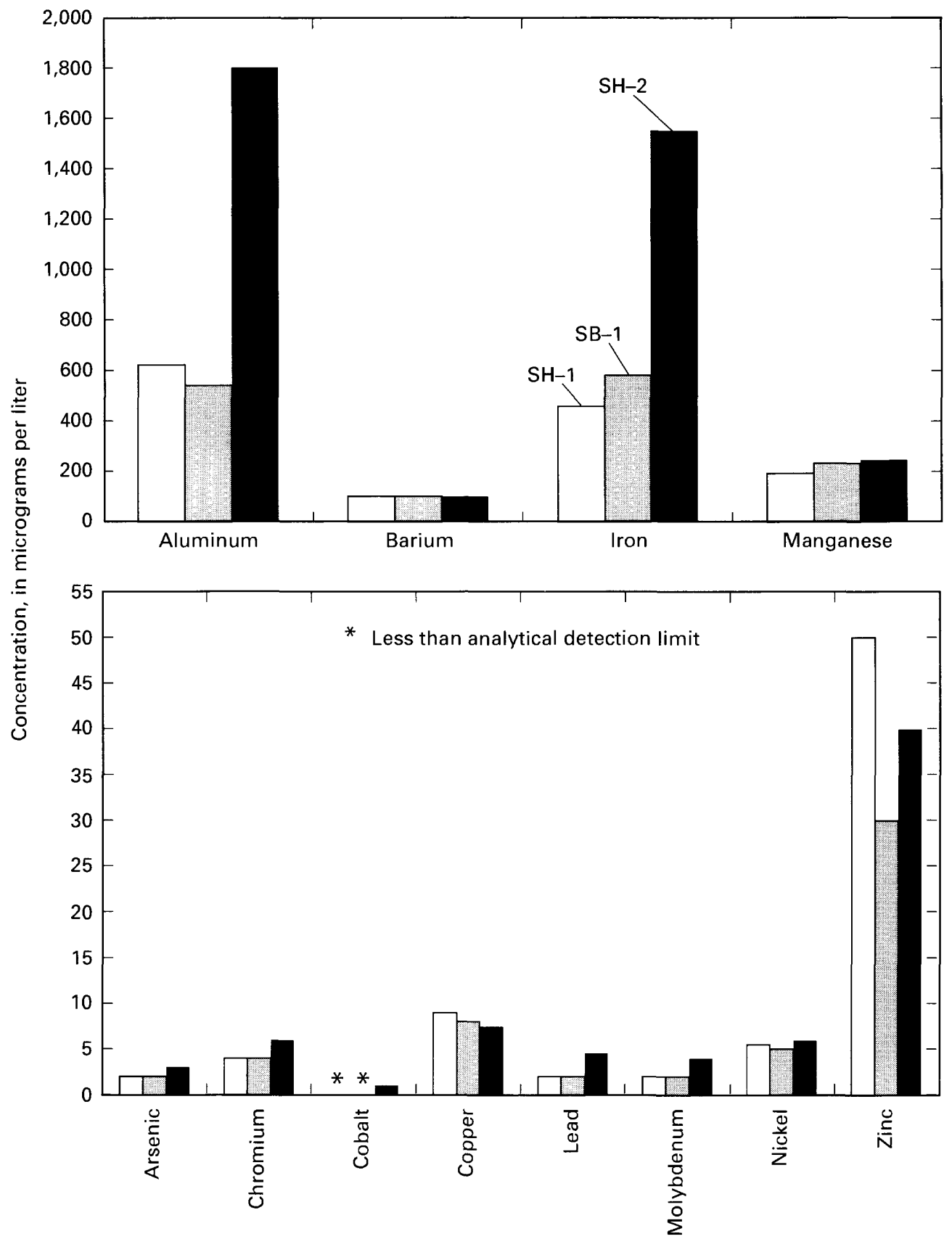

Figure 17. Comparison of median total recoverable concentrations of selected metals and trace elements in water from sampling sites SH-1, SB-1, and SH-2 in the Shunganunga Creek Basin, Topeka, Kansas, October 1993-September 1995. Location of sampling sites shown in figure 3 .

\section{Pesticides}

Many of the pesticides detected in water from the Shunganunga Creek Basin sampling sites also were detected in water from the Kansas River sampling sites. Some of these included the herbicides acetochlor, alachlor, atrazine, cyanazine, EPTC, metolachlor, prometon, simazine, and tebuthiuron, and the insecticide carbaryl. Detections of several other insecticides were limited to water from the Shunganunga Creek Basin sampling sites and included chlordane, chlorpyrifos, Diazinon, lindane, and malathion. Additionally, the herbicides pendimethalin, propanil, and trifluralin were detected in water from one or more of 
Table 10. Probability values ( $p$-values) calculated by the Wilcoxon rank-sum test comparing total recoverable concentrations of selected metals and trace elements between Shunganunga Creek Basin sampling sites $\mathrm{SH}-1$, $\mathrm{SB}-1$, and $\mathrm{SH}-2$ in Topeka, Kansas

[At a significance level of 0.05 , p-values greater than 0.025 for a two-tailed test indicate no significant difference in concentrations between sampling sites]

\begin{tabular}{cccccccccccccc}
\hline $\begin{array}{c}\text { Sampling- } \\
\text { site compari- } \\
\text { son (fig. 3) }\end{array}$ & $\begin{array}{c}\text { Alumi- } \\
\text { num }\end{array}$ & $\begin{array}{c}\text { Arse- } \\
\text { nic }\end{array}$ & Barium & $\begin{array}{c}\text { Chro- } \\
\text { mium }\end{array}$ & Cobalt & Copper & Iron & Lead & $\begin{array}{c}\text { Man- } \\
\text { ga- } \\
\text { nese }\end{array}$ & $\begin{array}{c}\text { Molyb- } \\
\text { denum }\end{array}$ & Nickel & Zinc \\
\hline SH-1 and SB-1 & \multicolumn{1}{c|}{0.650} & 0.900 & 0.104 & 0.508 & 0.577 & 0.480 & 0.749 & 0.333 & 0.255 & 0.873 & 0.389 & 0.052 \\
SH-1 and SH-2 & .004 & .035 & .213 & .105 & .082 & .895 & .004 & .054 & .004 & .002 & .639 & .185 \\
SB-1 and SH-2 & .002 & .035 & .797 & .016 & .024 & .455 & .006 & .006 & .150 & .002 & .184 & .440 \\
\hline
\end{tabular}

the Shunganunga Creek Basin sampling sites but not in water from the Kansas River sampling sites (table 11 in "Supplemental Information" section).

Most of the pesticides detected in water from the Shunganunga Creek Basin sampling sites were at small concentrations relative to Kansas River concentrations. Concentrations of some pesticides in water from the Shunganunga Creek Basin were as much as an order of magnitude less than in water from the Kansas River. No pesticide concentrations in water from the Shunganunga Creek Basin sampling sites exceeded Kansas Department of Health and Environment water-quality criteria. However, these are very limited data (four samples, at most, per sampling site) and, therefore, should be used with caution.

\section{Soldier Creek}

One sampling site was established on Soldier Creek to evaluate potential effects of urbanization (fig. 3 and table 1). This sampling site (SO-1) was located about $1 \mathrm{mi}$ downstream from an industrial area with a permitted point-source discharge of 4.62 Mgal $/ \mathrm{d}$. Eleven samples were collected at this sampling site from October 1993 through September 1995. A statistical summary of concentrations of selected water-quality constituents in water from sampling site SO-1 is presented in table 11 in the "Supplemental Information" section of this report.

\section{Major lons and Dissolved Solids}

Median concentrations of most major ions and dissolved solids were smaller in water from sampling site $\mathrm{SO}-1$ than in water from the other sampling sites in the study area. For example, a comparison of median concentrations of major ions and dissolved solids in water from sampling sites KR-2, SH-2, and SO-1 is presented in figure 18. The median concentration of dissolved solids in water from sampling site $\mathrm{SO}-1$ was at least 34 percent smaller than in water from either Kansas River sampling site (KR-1 and KR-2) and at least 6.1 percent smaller than in water from any sampling site in the Shunganunga Creek Basin. On the basis of the current data set, urbanization appears to have little effect on concentrations of major ions and dissolved solids in water from sampling site SO-1.

\section{Nutrients}

Median concentrations of selected nutrients in water from sampling site SO-1 are the smallest in water from any sampling site in the study area; however, they are similar to those median values documented in water from sampling site SB-1 (fig. 19). Sampling site SB-1 is not known to be affected by point-source discharges. Median concentrations of dissolved nitrate as nitrogen, total phosphorus, and dissolved orthophosphate as phosphorus in water from sampling site SO-1 were 23,11 , and 17 percent less, respectively, than corresponding median concentrations in water from sampling site SB-1. Median concentrations of total ammonia plus organic nitrogen as nitrogen were equal in water from sampling sites SO-1 and SB-1. On the basis of the current data set, urbanization appears to have little effect on median concentrations of nutrients in water from sampling site SO-1.

\section{Bacteria}

Median densities of fecal coliform bacteria in water from sampling site $\mathrm{SO}-1$ were some of the smallest median densities documented in water from any sampling site in the study area. For example, a comparison of median bacterial densities at sampling 


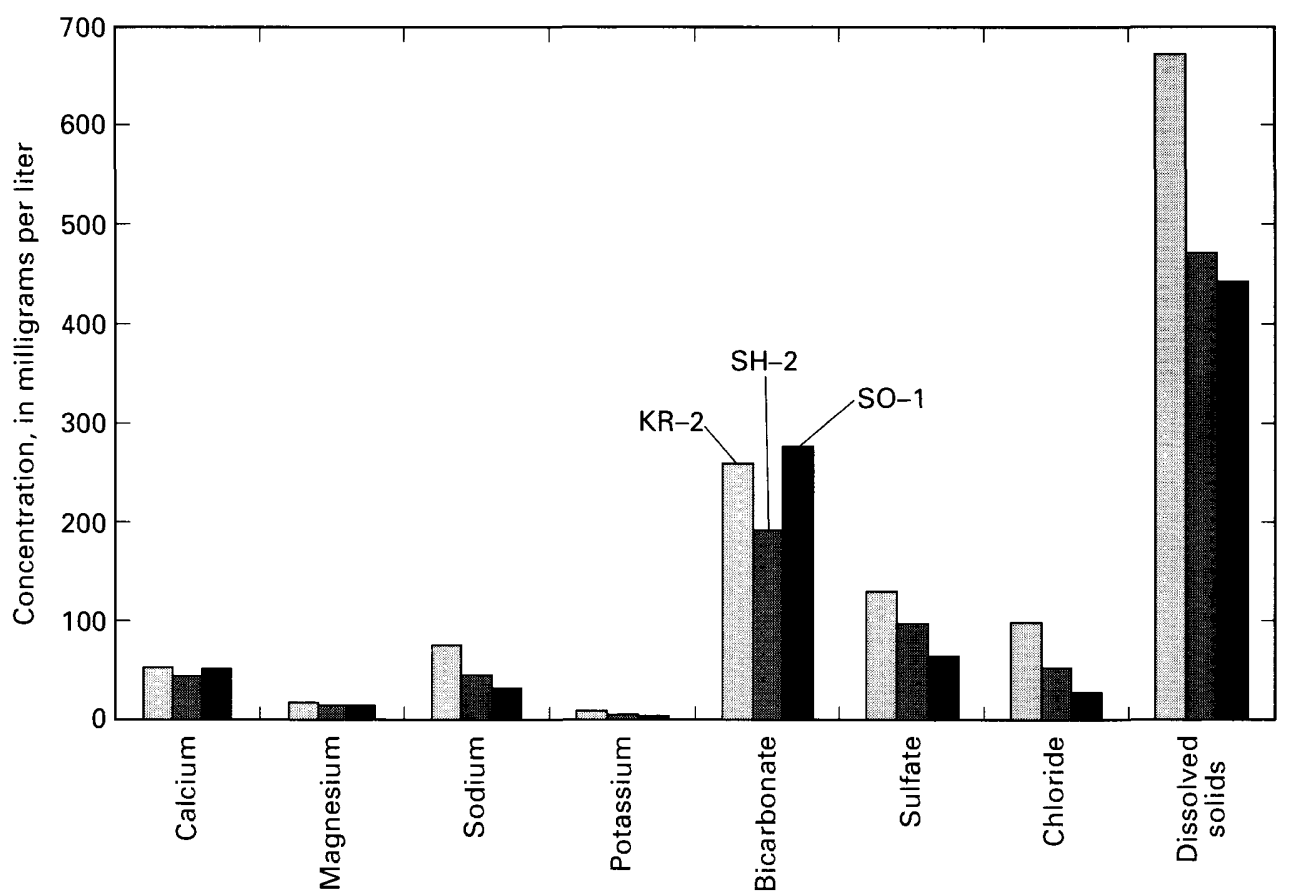

Figure 18. Comparison of median concentrations of major ions and dissolved solids in water from sampling sites KR-2 on the Kansas River, SH-2 on Shunganunga Creek, and SO-1 on Soldier Creek, Topeka, Kansas, October 1993-September 1995. Location of sampling sites shown in figure 3 .

sites $\mathrm{KR}-1, \mathrm{SH}-2$, and $\mathrm{SO}-1$ is presented in figure 20 . The median density of fecal coliform bacteria ( 25 cols $/ 100 \mathrm{~mL}$ ) in water from sampling site SO-1 was only 25 percent of the next largest median concentration ( 100 cols $/ 100 \mathrm{~mL}$, site $\mathrm{SH}-2)$ in water from any sampling site in the study area. However, median densities of fecal Streptococci bacteria in water from two other sampling sites (KR-1 and $\mathrm{SH}-2)$ were smaller than the median density of $90 \mathrm{cols} / 100 \mathrm{~mL}$ documented in water from sampling site SO-1 (table 11). Wastewater discharge upstream from sampling site SO-1 may have some effect on median densities of fecal Streptococci bacteria in water from sampling site SO-1. Additionally, livestock production in the mostly agricultural area upstream from sampling site SO-1 may be contributing to the density of Streptococci bacteria at that sampling site.

\section{Metals and Trace Elements}

A comparison of median total recoverable concentrations of selected metals and trace elements in water from sampling site SO-1 with sampling sites KR-2 on the Kansas River and SH-1 on Shunganunga Creek is presented in figure 21 . The median concentration of total recoverable aluminum in water from sampling site SO-1 was at least 31 percent less than median concentrations in water from any other sampling site. The median total recoverable barium concentration in water from sampling site SO-1 was equal to median concentrations documented in water from sampling sites on the Kansas River (fig. 11 and table 11), and the median total recoverable iron concentration was similar to the median concentration documented in water from sampling site SH-1 (fig. 17). The median concentration of total recoverable manganese in water from sampling site SO-1 $(400 \mu \mathrm{g} / \mathrm{L})$ was at least 74 percent larger than the median concentration in water from any other sampling site. The reason for this relatively large manganese concentration is not known but may be from upstream industrial discharge. Median total recoverable concentrations of metals and trace elements presented in figure 21 were similar to median concentration values documented in water from sampling sites in the Shunganunga Creek Basin (fig. 17).

\section{Pesticides}

Many of the pesticides detected in water from the Kansas River sampling sites (KR-1 and KR-2) also were detected in water from sampling site $\mathrm{SO}-1$ (table 11). Those pesticides detected in water from 


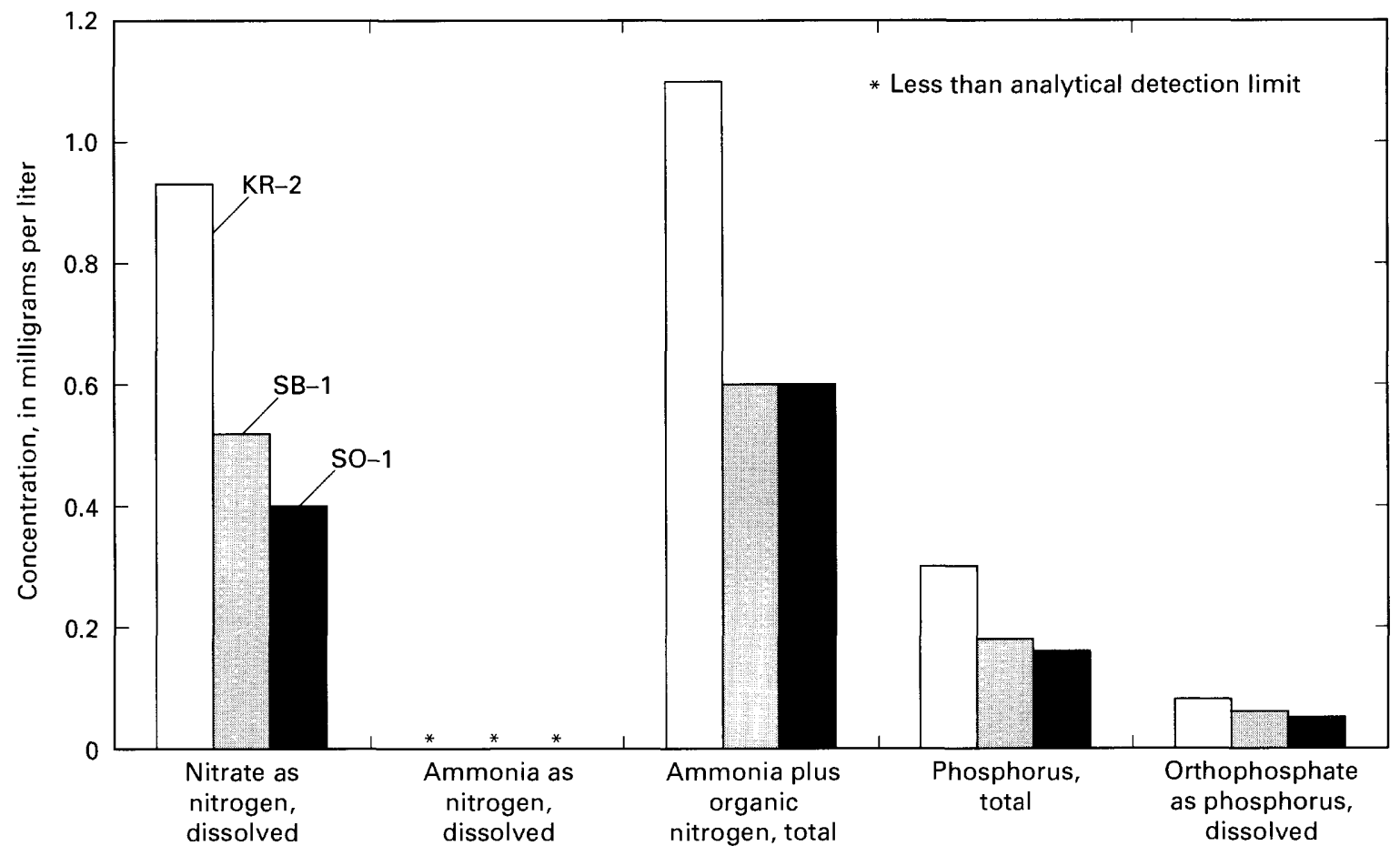

Figure 19. Comparison of median concentrations of selected nutrients in water from sampling sites KR-2 on the Kansas River, SB-1 on South Branch Shunganunga Creek, and SO-1 on Soldier Creek, Topeka, Kansas, October 1993-September 1995. Location of sampling sites shown in figure 3.

sampling site SO-1 are herbicides frequently used in crop production and include acetochlor, alachlor, atrazine, cyanazine, EPTC, metolachlor, metribuzin, and tebuthiuron. Insecticides detected in water from the Soldier Creek sampling site included carbaryl and carbofuran but not those insecticides commonly used in urbanized areas such as Diazinon, lindane, and malathion. Therefore, on the basis of the current data set, urbanization appears to have little appreciable effect on concentrations of pesticides in water from sampling site $\mathrm{SO}-1$. No concentrations of pesticides exceeded Kansas Department of Health and Environment (1994) water-quality criteria.

\section{SUMMARY}

The water of streams in urban areas potentially may be degraded through the point- and nonpoint-source discharge of major ions, dissolved solids, nutrients, bacteria, metals and trace elements, and pesticides. Stream degradation may cause the water to be unsuitable for irrigation; pose potential public health problems in processed drinking water; inhibit growth, reproduction, and diversity of aquatic organisms; and reduce recreational desirability of the stream.
In 1993, the U.S. Geological Survey entered into a cooperative agreement with the city of Topeka, Kansas, to determine and evaluate stream-water quality in the urbanized sections of the Kansas River, Shunganunga Creek Basin, and Soldier Creek. The Kansas River at Topeka, Kansas, represents a drainage area of $56,720 \mathrm{mi}^{2}$ of mostly agricultural land and serves as a water-supply source for the city of Topeka. The city's primary wastewater-treatment plant discharges into the Kansas River. Much of the $60-\mathrm{mi}^{2}$ drainage area of Shunganunga Creek is urbanized, and the creek receives point- and nonpoint-source discharges as it flows through the city. The $305-\mathrm{mi}^{2}$ drainage area of Soldier Creek is almost entirely agricultural but potentially receives urban point- and nonpoint-source discharges from the northern part of the city.

For the purpose of monitoring the effects of urban. ization on streams within the city of Topeka, a network of seven sampling sites was established in the study area. Two sampling sites were located on the Kansas River (upstream and downstream from an urbanized area); one site at the discharge from the Oakland Wastewater Treatment Plant (downstream from the last Kansas River sampling site); three in the Shunganunga Creek Basin (upstream and downstream from the major urbanized area and on an intervening tributary); and 


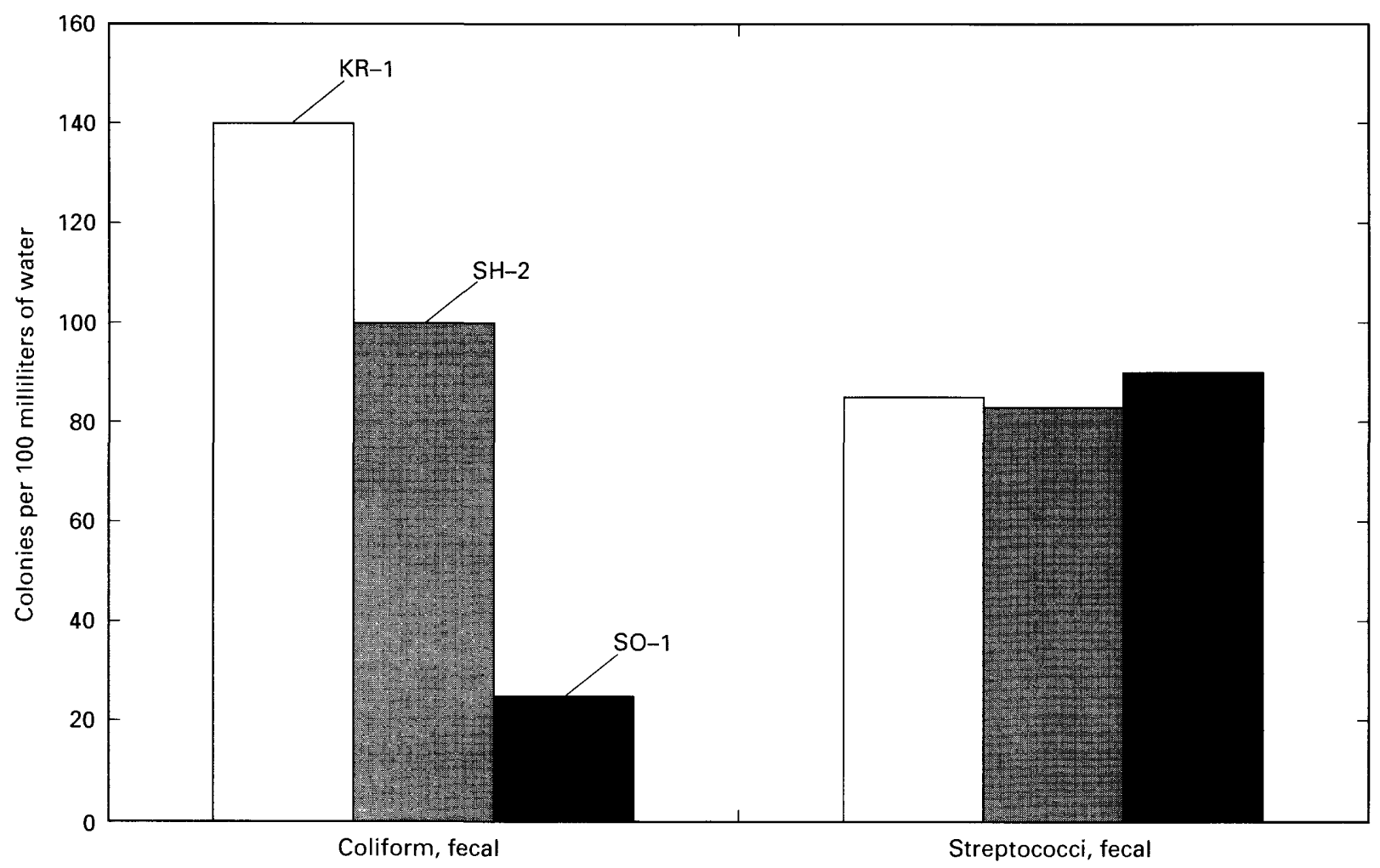

Figure 20. Comparison of median densities of fecal coliform and fecal Streptococci bacteria in water from sampling sites KR-1 on the Kansas River, SH-2 on Shunganunga Creek, and SO-1 on Soldier Creek, Topeka, Kansas, October 1993-September 1995. Location of sampling sites shown in figure 3.

one on Soldier Creek. Most samples were collected during periods of stable, dry-weather flow (nonrunoff periods); however, about two samples at each site were collected when streamflow was affected by runoff.

No significant differences in median concentrations of dissolved solids, nutrients, or metals and trace elements, or median densities of fecal bacteria were documented between the upstream and downstream sampling sites on the Kansas River. This indicates that nonpoint-source discharge from Topeka has little effect on median concentrations in water from the Kansas River during stable, dry-weather periods. The greatest potential source of contamination to the Kansas River is discharge from the Oakland Wastewater Treatment Plant.

Large quantities of dissolved ammonia are discharged from the Oakland Wastewater Treatment Plant and substantially increase dissolved ammonia as nitrogen concentrations in water from the Kansas River. Dissolved ammonia as nitrogen concentrations in water from the Kansas River resulting from this discharge ranged from 0.03 to $1.1 \mathrm{mg} / \mathrm{L}$. However, as a percentage of water-quality criteria, most of the resulting dissolved ammonia as nitrogen concentrations in water from the Kansas River were considerably less than 50 percent of the Kansas Department of Health and Environment's water-quality criterion, with a median value of 20 percent of the criterion (on the basis of 26 samples).

Concentrations of total phosphorus in discharge from the Oakland Wastewater Treatment Plant were relatively large compared to concentrations in water from the Kansas River. However, discharges of total phosphorus from this plant produced only small increases in concentrations in water from the Kansas River. Generally, treatment-plant discharge increased calculated total phosphorus concentrations in water from the Kansas River by 0.01 to $0.04 \mathrm{mg} / \mathrm{L}$. The median percentage increase in total phosphorus concentrations in water from the Kansas River was 7.6 percent.

Bacterial densities in discharge from the Oakland Wastewater Treatment Plant substantially increased densities in water from the Kansas River. The median fecal coliform density in water from the Kansas River upstream from the plant was 120 cols $/ 100 \mathrm{~mL}$ of water, whereas the calculated median density after receiving plant discharge was $4,900 \mathrm{cols} / 100 \mathrm{~mL}$ of water. 

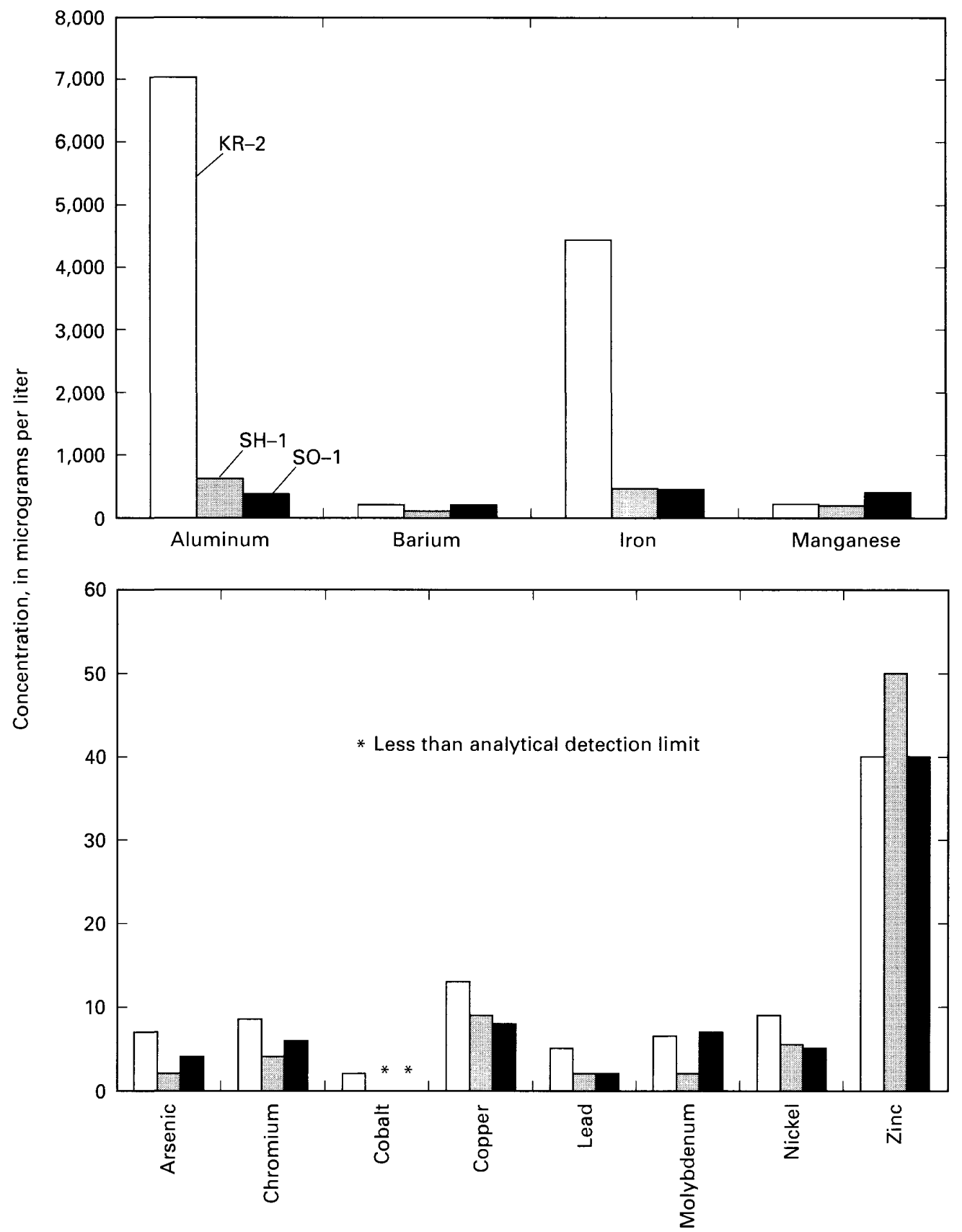

Figure 21. Comparison of median total recoverable concentrations of selected metals and trace elements in water from sampling sites KR-2 on the Kansas River, $\mathrm{SH}-1$ on Shunganunga Creek, and SO-1 on Soldier Creek, Topeka, Kansas, October 1993-September 1995. Location of sampling sites shown in figure 3 .

Calculated densities of fecal coliform bacteria in water from the Kansas River as a result of wastewater discharge exceeded the $200 \mathrm{cols} / 100 \mathrm{~mL}$ of water criterion established by the Kansas Department of Health and Environment in 100 percent of the samples compared to 35 percent of the Kansas River samples col- lected upstream from the plant discharge. Median densities of fecal Streptococci bacteria in water from the Kansas River increased from 150 cols $/ 100 \mathrm{~mL}$ of water upstream from plant discharge to $4,700 \mathrm{cols} /$ $100 \mathrm{~mL}$ of water downstream from plant discharge.

40 Effects of Urbanization on Water Quality in the Kansas River, Shunganunga Creek Basin, and Soldier Creek, Topeka, Kansas, October 1993 Through September 1995 
Median concentrations of dissolved solids were not significantly different between the three sampling sites in the Shunganunga Creek Basin. Median concentrations of dissolved nitrate as nitrogen, total phosphorus, and dissolved orthophosphate as phosphorus were significantly larger in water from the upstream-most sampling site than in water from either of the other sites. Discharge from the Sherwood Lake Wastewater Treatment Plant is probably responsible for these larger upstream median concentrations. Median concentrations of total ammonia plus organic nitrogen as nitrogen were significantly larger in water from the main-stem Shunganunga Creek sampling sites than in water from the tributary sampling site probably because of wastewater discharge into the main stem.

A comparison of median concentrations of selected water-quality constituents in dry-weather streamflow from the current (1993-95) study with a previous (1979-81) Shunganunga Creek study indicated that median concentrations of dissolved nitrate as nitrogen and total phosphorus during 1993-95 in water from upstream sampling sites were either significantly larger than during 1979-81 in response to increases of wastewater-treatment plant discharge or smaller because of the elimination of wastewater-treatment plant discharge. Median concentrations of ammonia as nitrogen concentrations were significantly less during 1993-95 than during 1979-81.

Median densitites of fecal bacteria were largest in water from the upstream-most Shunganunga Creek sampling site and smallest in water from the downstream-most sampling site. However, because effluent from the Sherwood Lake Wastewater Treatment Plant is chlorinated (disinfected) before discharge to Shunganunga Creek, it is believed that the larger upstream median densities represent mostly nonpoint-source contributions from wildlife and livestock.

Median concentrations for 4 of 12 metals and trace elements were significantly larger in water from the downstream-most Shunganunga Creek sampling site than in water from the upstream-most sampling site. These metals and trace elements included total aluminum, iron, manganese, and molybdenum, and their occurrence in larger concentrations in water from the downstream-most sampling site probably is a result of their widespread use in the urban environment.

Little water-quality effect from urbanization was indicated by results from the Soldier Creek sampling site. Median concentrations of most water-quality constituents in water from this sampling site were the smallest in water from any sampling site in the study area.

Herbicides frequently used in the production of corn, grain sorghum, and soybeans were detected in water from all sampling sites. These included acetochlor, alachlor, atrazine, cyanazine, EPTC, metolachlor, prometon, simazine, and tebuthiuron.

Additionally, insecticides frequently used in the urban environment were detected in water from the Shunganunga Creek Basin and in discharge from the Oakland Wastewater Treatment Plant. These insecticides included chlordane, chlorpyrifos, Diazinon, lindane, and malathion. No pesticide concentrations exceeded Kansas Department of Health and Environment water-quality criteria.

Although the scope of this study included an examination of both point and nonpoint sources of potential contamination, few samples were collected during runoff when nonpoint-source effects would be largest. Therefore, conclusions pertaining to the possible effects of nonpoint-source contamination should be used with discretion.

\section{REFERENCES CITED}

Abmeyer, Walter, and Campbell, H.V., 1970, Soil survey of Shawnee County, Kansas: U.S. Soil Conservation Service, 77 p.

American Public Health Association, American Water Works Association, and Water Pollution Control Federation, 1985, Standard methods for the examination of water and waste (16th ed.): Washington, D.C., American Public Health Association, 1268 p.

Britton, L.J., and Greeson, P.E., eds., 1989, Methods for collection and analysis of aquatic biological and microbiological samples: U.S. Geological Survey Techniques of Water-Resources Investigations, book 5, chap. A4, $363 \mathrm{p}$.

Buchanan, T.J., and Somers, W.P., 1976, Discharge measurements at gaging stations: U.S. Geological Survey Techniques of Water-Resources Investigations, book 3, chap. A8, $65 \mathrm{p}$.

Carswell, W.J., Jr., 1978, Description of data-collection system and synopsis of selected hydrologic data for Soldier Creek basin, Kansas: U.S. Geological Survey Open-File Report 78-678, 79 p.

1981, Selected hydrologic relationships for Soldier Creek, northeastern Kansas: U.S. Geological Survey Water-Resources Investigations 81-8, $68 \mathrm{p}$. 
Decker, T.J., Siewert, H.F., and Dodish, T.G., 1988, An assessment of water quality on Little and Big Duck Creeks near Elwood, Indiana: Proceedings of the Indiana Academy of Science, v. 97, p. 333-338.

Doran, J.W., Schepers, J.S., and Swanson, N.P., 1981, Chemical and bacteriological quality of pasture rụnoff: Journal of Soil and Water Conservation, v. 36, no. 3, p. $166-171$.

Dorney, J.R., 1986, Leachable and total phosphorus in urban street tree leaves: Water, Air, and Soil Pollution, v. 28, no. $3 / 4$, p. $439-443$.

Edwards, T.K., and Glysson, G.D., 1988, Field methods for measurements of fluvial sediment: U.S. Geological Survey Open-File Report 86-531, 118 p.

Evaldi, R.D., Burns, R.J., and Moore, B.L., 1993, Water quality of selected streams in Jefferson County, Kentucky, 1988-91: U.S. Geological Survey WaterResources Investigations Report 92-4150, 177 p.

Fallon, J.D., and McChesney, J.A., 1993, Surface-waterquality assessment of the lower Kansas River basin, Kansas and Nebraska-project data, November 1986 through April 1990: U.S. Geological Survey Open-File Report 93-51, $594 \mathrm{p}$.

Fenneman, N.M., 1946, Physical divisions of the United States: Washington, D.C., U.S. Geological Survey special map, 1 sheet, scale 1:7,000,000.

Fishman, M.J., ed., 1993, Methods of analysis by the U.S. Geological Survey National Water Quality Laboratory-determination of inorganic and organic constituents in water and fluvial sediments: U.S. Geological Survey Open-File Report 93-125, 217 p.

Geiger, C.O., Lacock, D.L., Schneider, D.R., Carlson, M.D., and Dague, B.J., 1995, Water resources data, Kansas, water year 1994: U.S. Geological Survey Water-Data Report KS-94-1, 479 p.

Gilbert, R.O., 1987, Statistical methods for environmental pollution monitoring: New York, Van Nostrand Reinhold, $320 \mathrm{p}$.

Gray, H.L., Johnson, S.R., and Ponce, J.L., 1983, Cattle grazing impact on surface water quality in a Colorado front range stream: Journal of Soil and Water Conservation, v. 38 , no. 2 , p. $124-128$.

Helgesen, J.O., ed., 1996, Surface-water-quality assessment of the lower Kansas River basin, Kansas and Nebraska-results of investigations, 1987-90: U.S. Geological Survey Water-Supply Paper 2451, 129 p.

Hem, J.D., 1985, Study and interpretation of the chemical characteristics of natural water ( $3 d$ ed.): U.S. Geological Survey Water-Supply Paper 2254, 263 p.

Horowitz, A.J., Demas, C.R., Fitzgerald, K.K., Miller, T.L., and Rickert, D.A., 1994, U.S. Geological Survey protocol for the collection and processing of surface-water samples for the subsequent determination of inorganic constituents in filtered water: U.S. Geological Survey Open-File Report 94-539, 57 p.
Jordan, P.R., and Stamer, J.K., eds., 1995, Surface-waterquality assessment of the lower Kansas River basin, Kansas and Nebraska-analysis of available data through 1986: U.S. Geological Survey Water-Supply Paper 2352-B, $161 \mathrm{p}$.

Kansas Department of Health and Environment, 1994, Kansas register: Topeka, Kansas Secretary of State, v. 13, no. 28, p. 1050-1062.

Kennedy, E.J., 1983, Computation of continuous records of streamflow: U.S. Geological Survey Techniques of Water-Resources lnvestigations, book 3, chap. A13, $53 \mathrm{p}$.

Litke, D.W., 1996, Sources and loads of nutrients in the South Platte River, Colorado and Nebraska: U.S. Geological Survey Water-Resources Investigations Report 96-4029, $31 \mathrm{p}$.

Lopes, T.J., and Fossum, K.D., 1995, Selected chemical characteristics and acute toxicity of urban stormwater, streamflow, and bed material, Maricopa County, Arizona: U.S. Geological Survey Water-Resources Investigations Report 95-4074, 52 p.

Martin, J.D., 1995, Effects of combined-sewer overflows and urban runoff on the water quality of Fall Creek, Indianapolis, Indiana: U.S. Geological Survey Water-Resources Investigations Report 94-4066, 92 p. National Oceanic and Atmospheric Administration, 1992, Monthly station normals of temperature, precipitation, and heating and cooling degrees days 1961-1990, Kansas: Asheville, N.C., National Climatic Center, 36 p. -1993-95, Climatological data, Kansas, annual summary: Asheville, N. C., National Climatic Center [published annually].

Norman, C.G., 1991, Urban runoff effects on Ohio River water quality: Water Environment and Technology, v. 3, no. 6, p. $44-46$.

Pope, L.M., 1995, Surface-water-quality assessment of the lower Kansas River basin, Kansas and Nebraska-dissolved oxygen and Escherichia coli bacteria in streams during low flow, July 1988 through July 1989: U.S. Geological Survey Water-Resources Investigations Report 94-4077, 102 p.

Pope, L.M., and Bevans, H.E., 1987, Relation of urban land-use and dry-weather, storm, and snowmelt flow characteristics to stream-water quality, Shunganunga Creek basin, Topeka, Kansas: U.S. Geological Survey Water-Supply Paper 2283, 39 p.

Pope, L.M., Diaz, A.M., and Butler, M.K., 1983, Urban water-quality data and statistical summaries for selected sites in the Shunganunga Creek basin, Topeka, Kansas: Kansas Department of Health and Environment Bulletin No. B2-49, 203 p.

Putnam, J.E., Lacock, D.L., Schneider, D.R., Carlson, M.D., and Dague, B.J., 1996, Water resources data, Kansas, water year 1995: U.S. Geological Survey Water-Data Report KS-95-1, 488 p. 
Reid, G.K., and Wood, R.D., 1976, Ecology of inland waters and estuaries: New York, D. Van Nostrand Co., 485 p.

Rich, P.H., and Murray, T.E., 1990, De-icing salts in an urban drainage basin: Internationale Vereinigung fuer Theoretische und Angewandte Limnologie, v. 24, no. 1, p. 162-165.

Segfried, P.L., Brown, N.E., Cherwinsky, C.L., Jenkins, G.D., and Cotter, D.A., 1984, Impact of sewage treatment plants on surface waters: Canadian Journal of Public Health, v. 75, no. 1, p. 25-31.

Stephenson, G.R., and Street, L.V., 1978, Bacterial variations in streams from a southwest Idaho rangeland watershed: Journal of Environmental Quality, v. 7, no. 1, p. 150-157.

Stewart, P.M., and Robinson, D.J., 1992, Aquatic organisms as indicators of water quality in suburban streams of the lower Delaware River region, USA: Journal of the Pennsylvania Academy of Science, v. 66, no. 3, p. 135-141.

Taylor, G.F., 1990, Quantity and quality of stormwater runoff from western Dayton Beach, Florida, and adjacent areas: U.S. Geological Survey Water-Resources Investigations Report 90-4002, 88 p.

U.S. Environmental Protection Agency, 1983, Environmental impact statement draft metropolitan Topeka proposed wastewater treatment facilities, Shawnee County, Kansas: U.S. Environmental Protection Agency, EPA/9-83/001, $230 \mathrm{p}$.
1984, Report to Congress-nonpoint source pollution in the U.S.: U.S. Environmental Protection Agency [variously paged].

1986, Quality criteria for water, 1986: U.S. Environmental Protection Agency Report 440/5-86-001 [variously paged].

U.S. Geological Survey, 1981, Water-resources data for Kansas, water year 1980-volume 1, Missouri River basin: U.S. Geological Survey Water-Data Report KS-80-1, 422 p.

1982, Water-resources data for Kansas, water year 1981: U.S. Geological Survey Water-Data Report KS-81-1, 566 p.

U.S. Soil Conservation Service, 1975, Urban hydrology for small watersheds: U.S. Soil Conservation Service Technical Release No. 55 [unnumbered pages].

Veenhuis, J.E., and Slade, R.M., 1990, Relation between urbanization and water quality of streams in the Austin area, Texas: U.S. Geological Survey Water-Resources Investigations Report 90-4107, 64 p.

Wershaw, R.L., Fishman, M.J., Grabbe, R.R., and Lowe, L.E., eds., 1987, Methods for determination of organic substances in water and fluvial sediments: U.S. Geological Survey Techniques of Water-Resources Investigations, book 5, chap. A3, 80 p.

Wonnacott, T.H., and Wonnacott, R.J., 1977, Introductory statistics: New York, John Wiley and Sons, 650 p. 
44 Effects of Urbanization on Water Quality in the Kansas River, Shunganunga Creek Basin, and Soldier Creek, Topeka, Kansas, October 1993 Through September 1995 


\section{SUPPLEMENTAL INFORMATION}




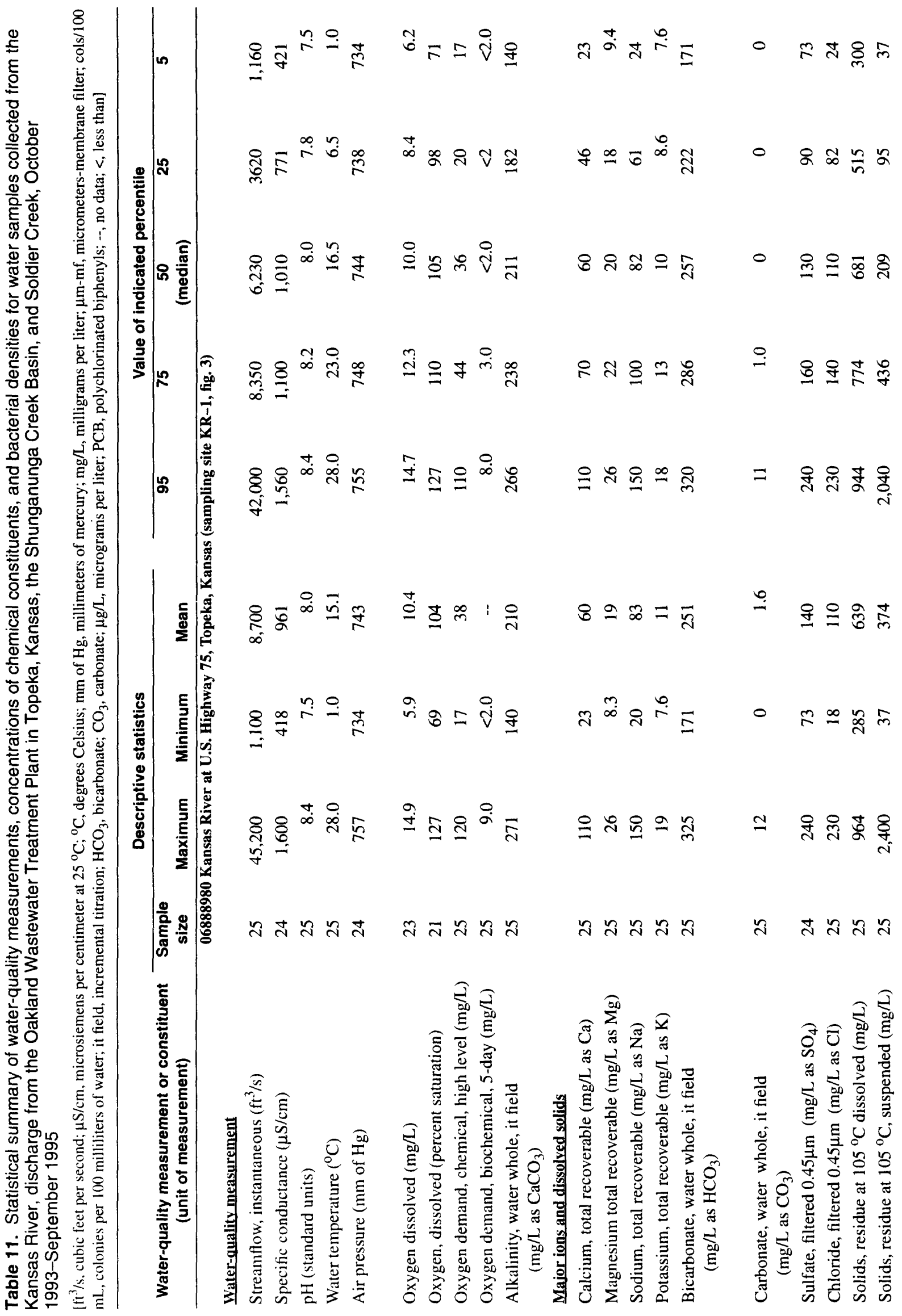

46 Effects of Urbanization on Water Quality in the Kansas River, Shunganunga Creek Basin, and Soldier Creek, Topeka, Kansas, October 1993 Through September 1995 


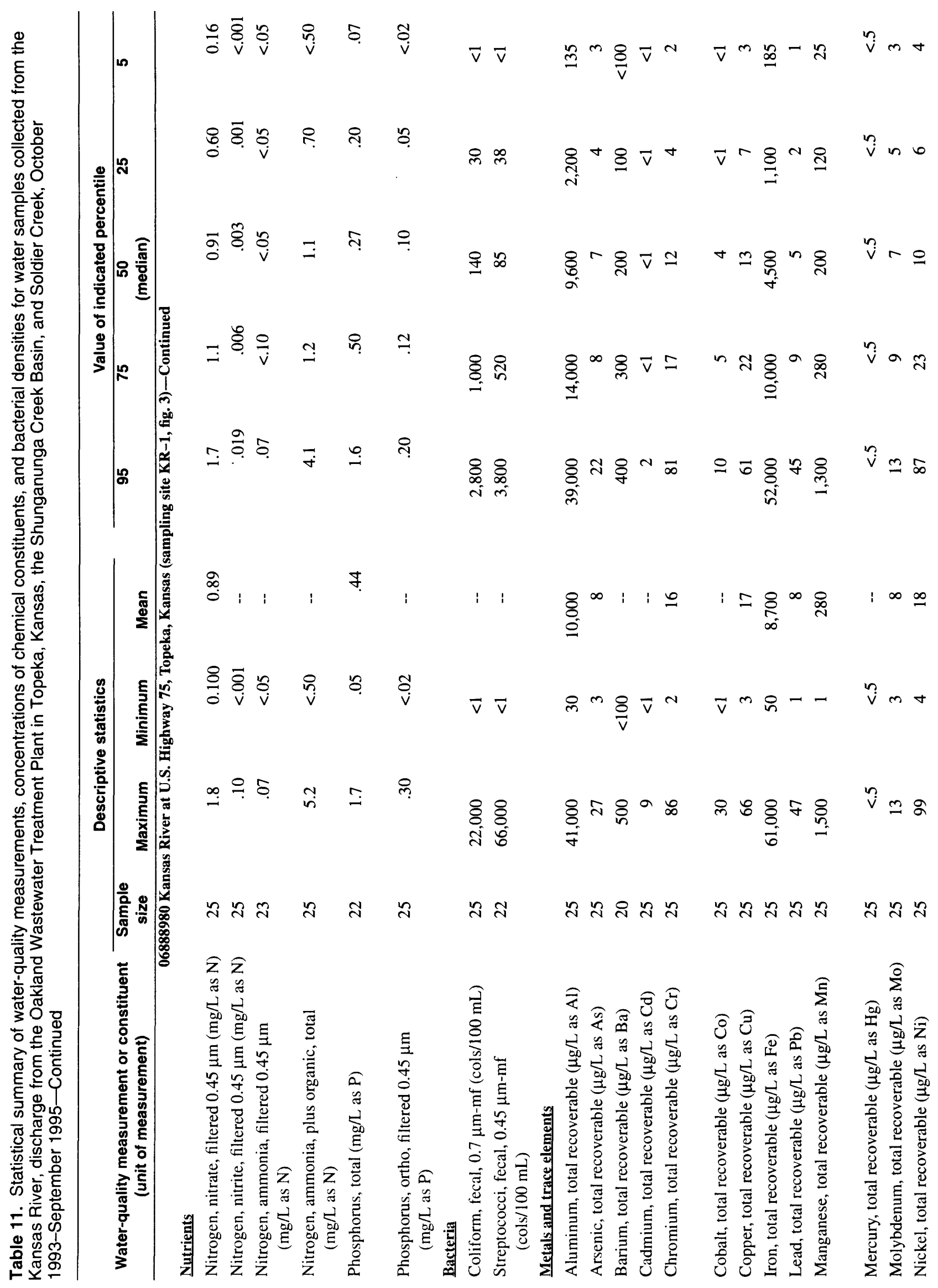




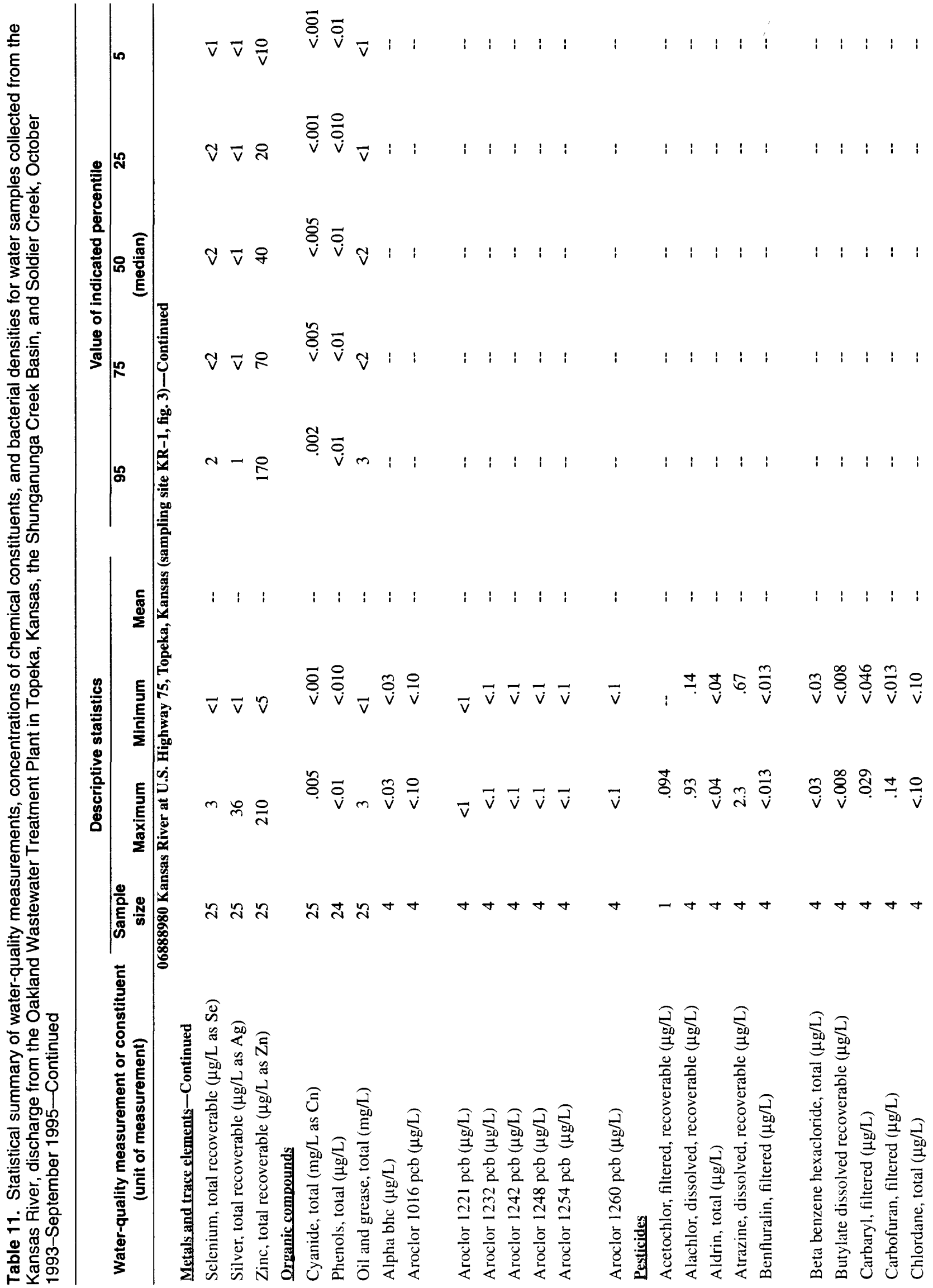

48 Effects of Urbanization on Water Quality in the Kansas River, Shunganunga Creek Basin, and Soldier Creek, Topeka, Kansas, October 1993 Through September 1995 


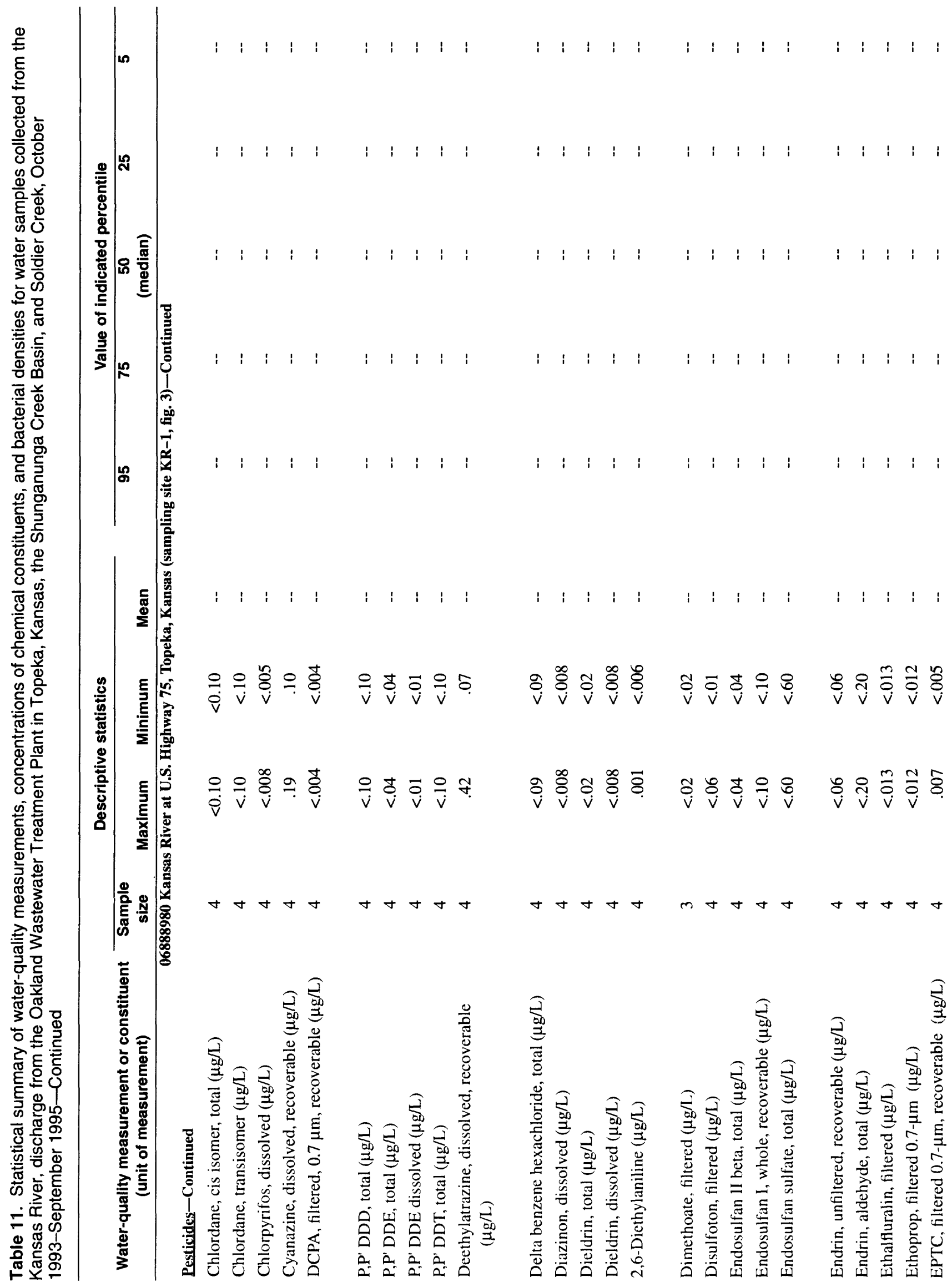




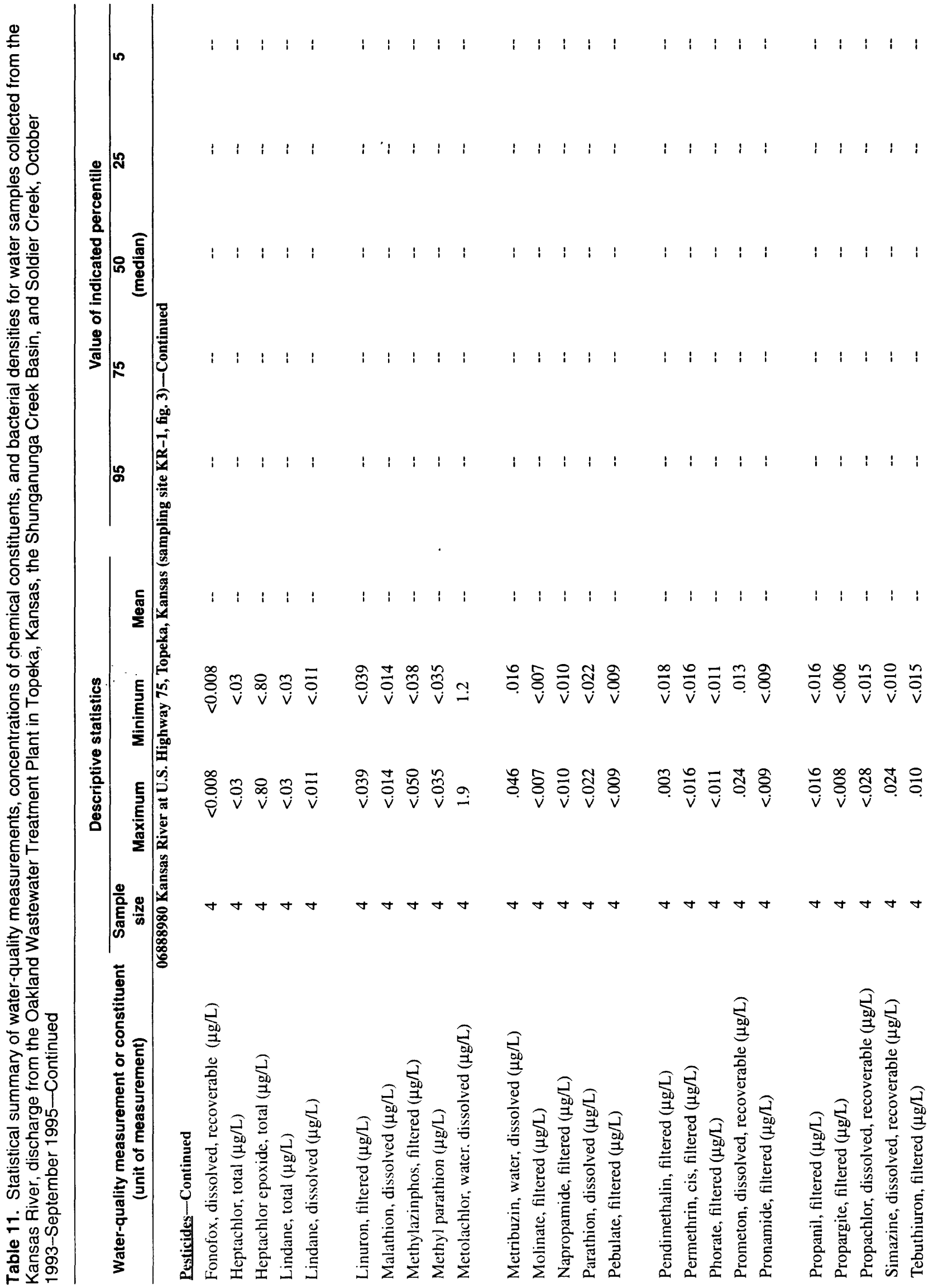

50 Effects of Urbanization on Water Quality in the Kansas River, Shunganunga Creek Basin, and Soldier Creek, Topeka, Kansas, October 1993 Through September 1995 


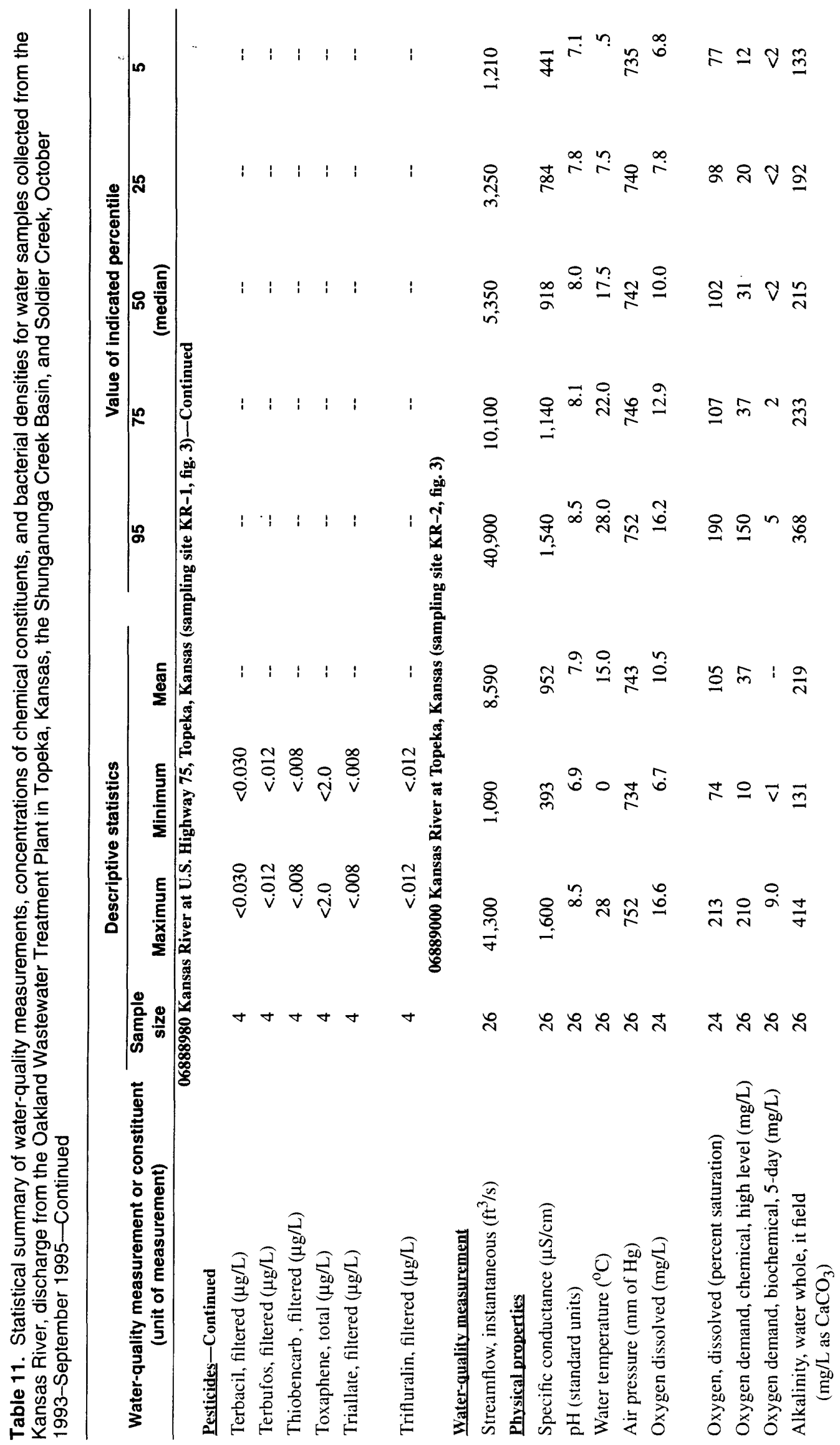




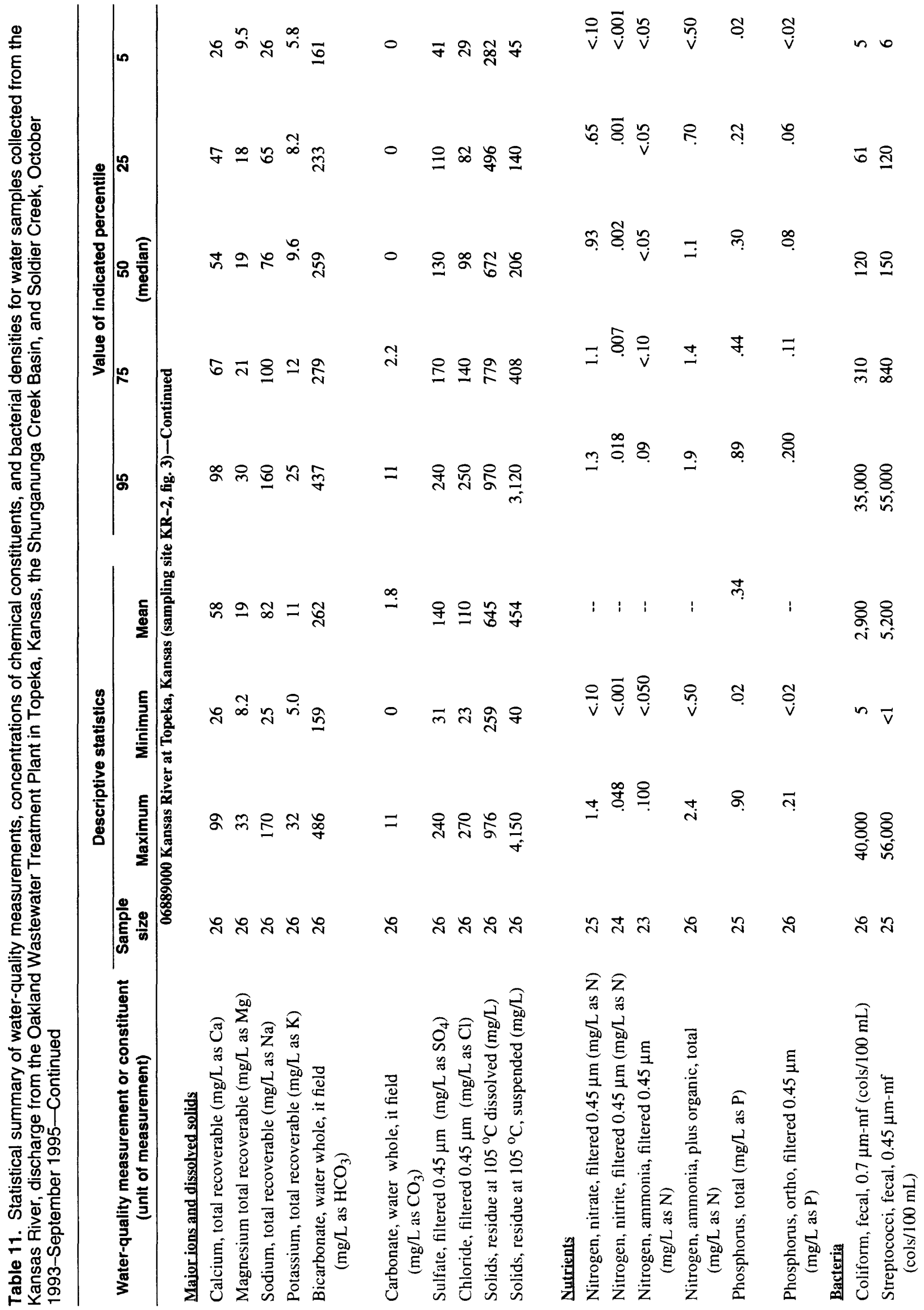

52 Effects of Urbanization on Water Quality in the Kansas River, Shunganunga Creek Basin, and Soldier Creek Topeka, Kansas, October 1993 Through September 1995 


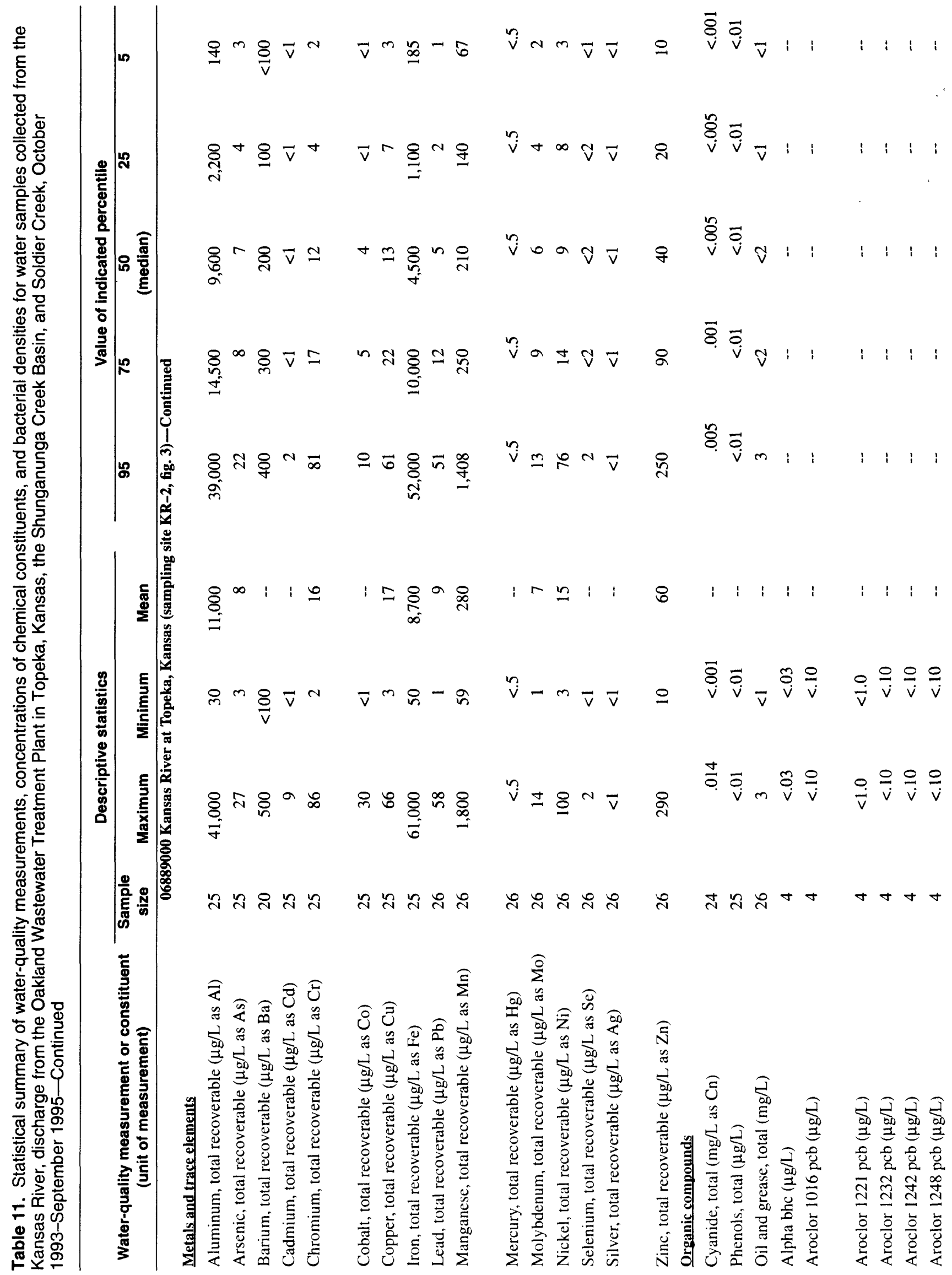




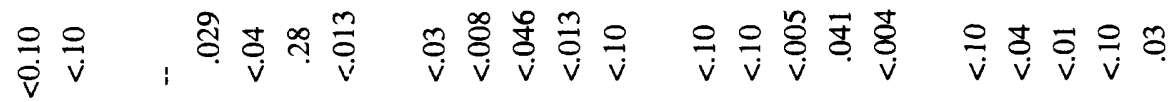

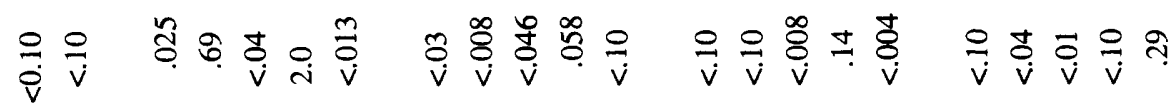

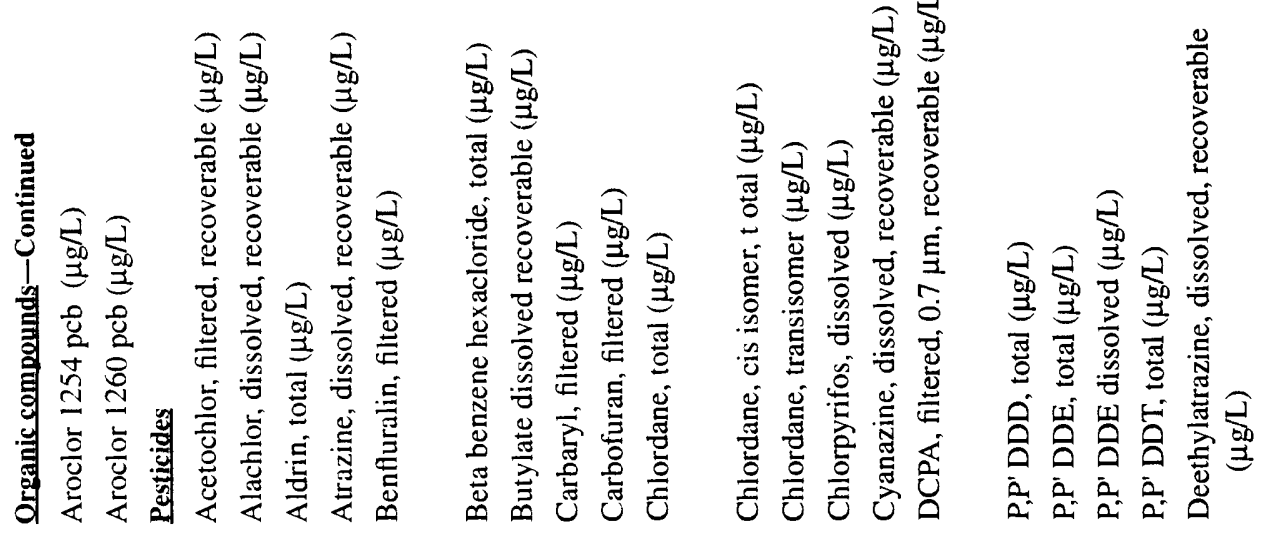

54 Effects of Urbanization on Water Quality in the Kansas River, Shunganunga Creek Basin, and Soldier Creek Topeka, Kansas, October 1993 Through September 1995 


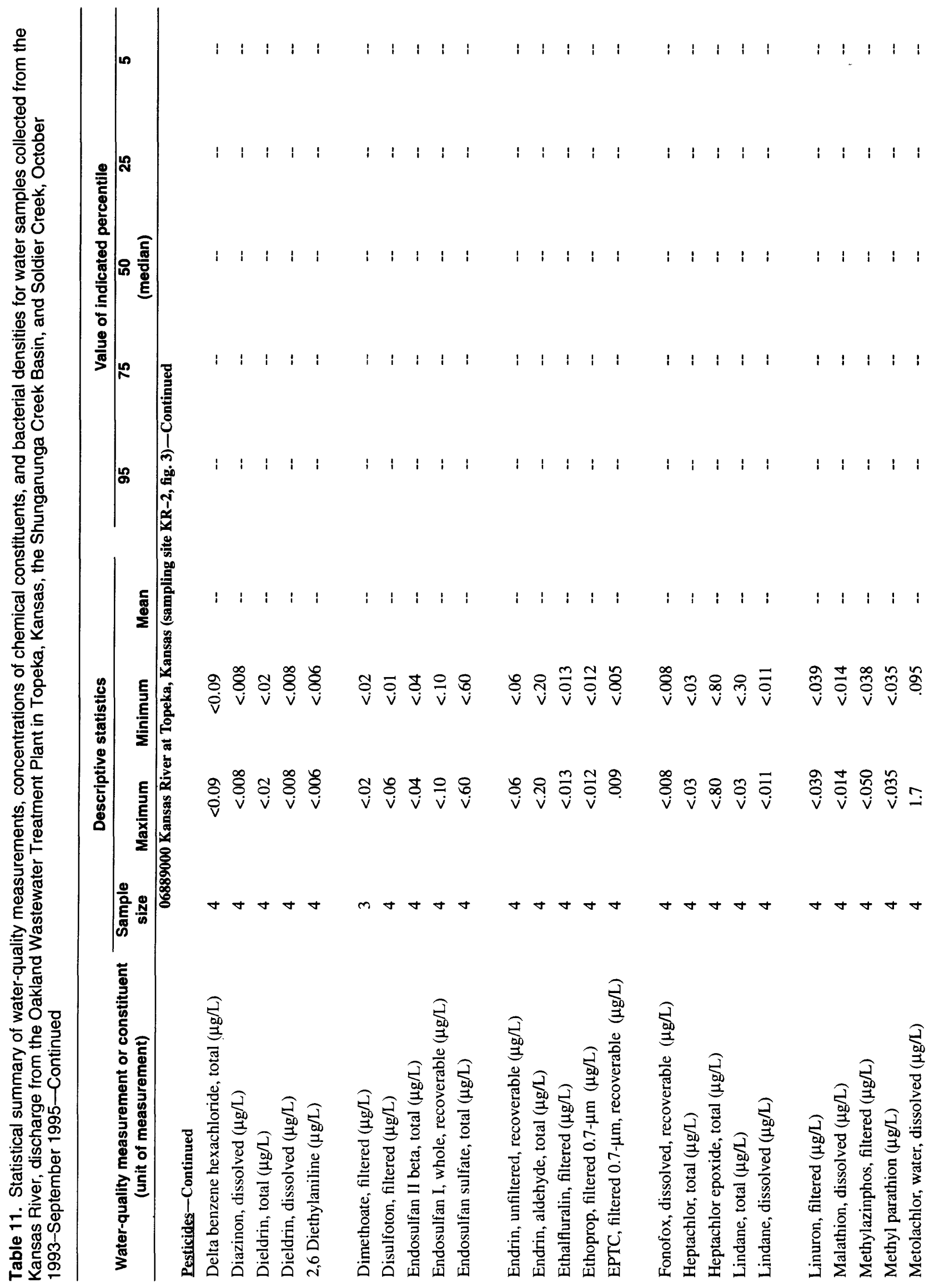




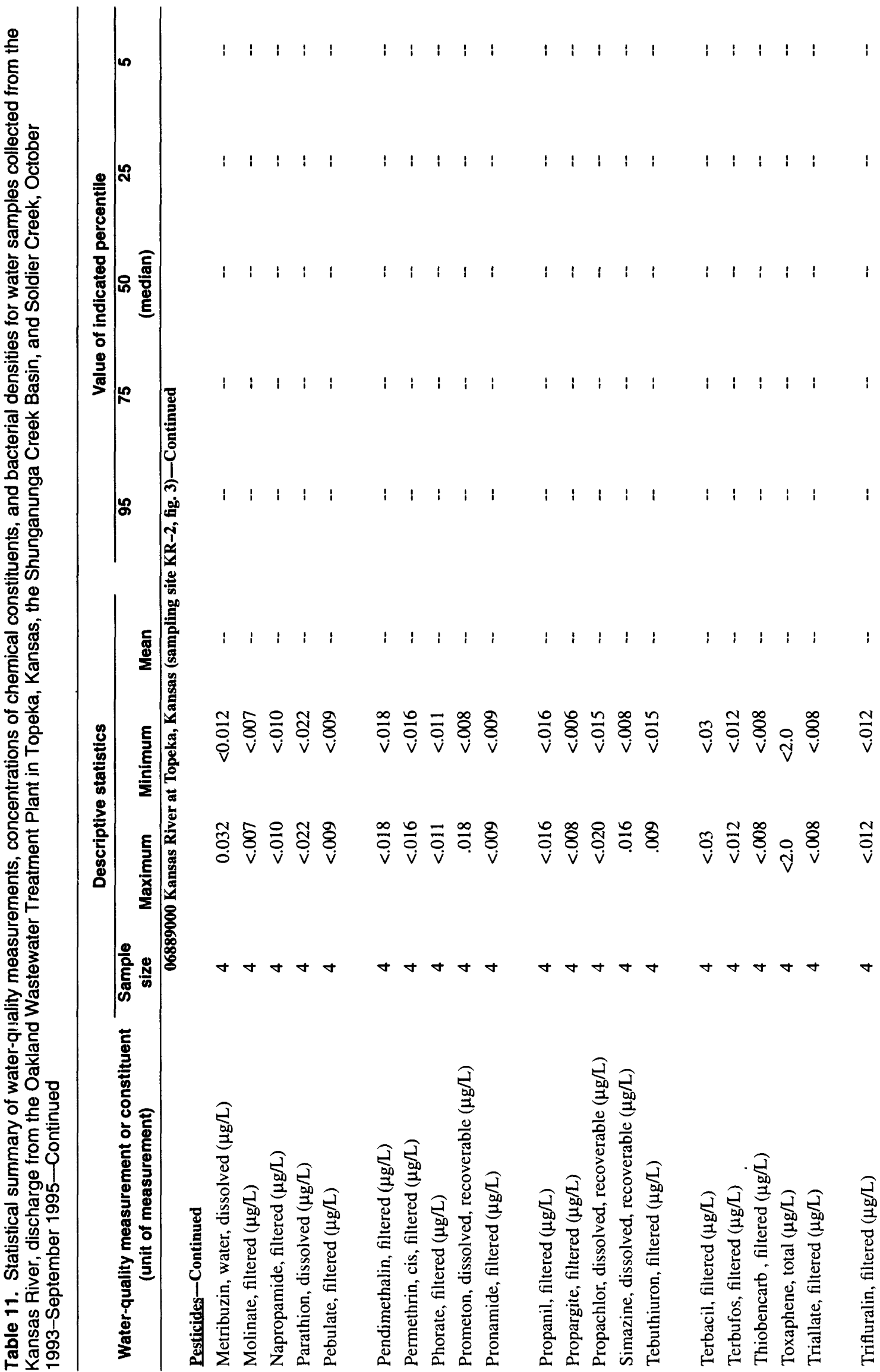

56 Effects of Urbanization on Water Quality in the Kansas River, Shunganunga Creek Basin, and Soldier Creek Topeka, Kansas, October 1993 Through September 1995 


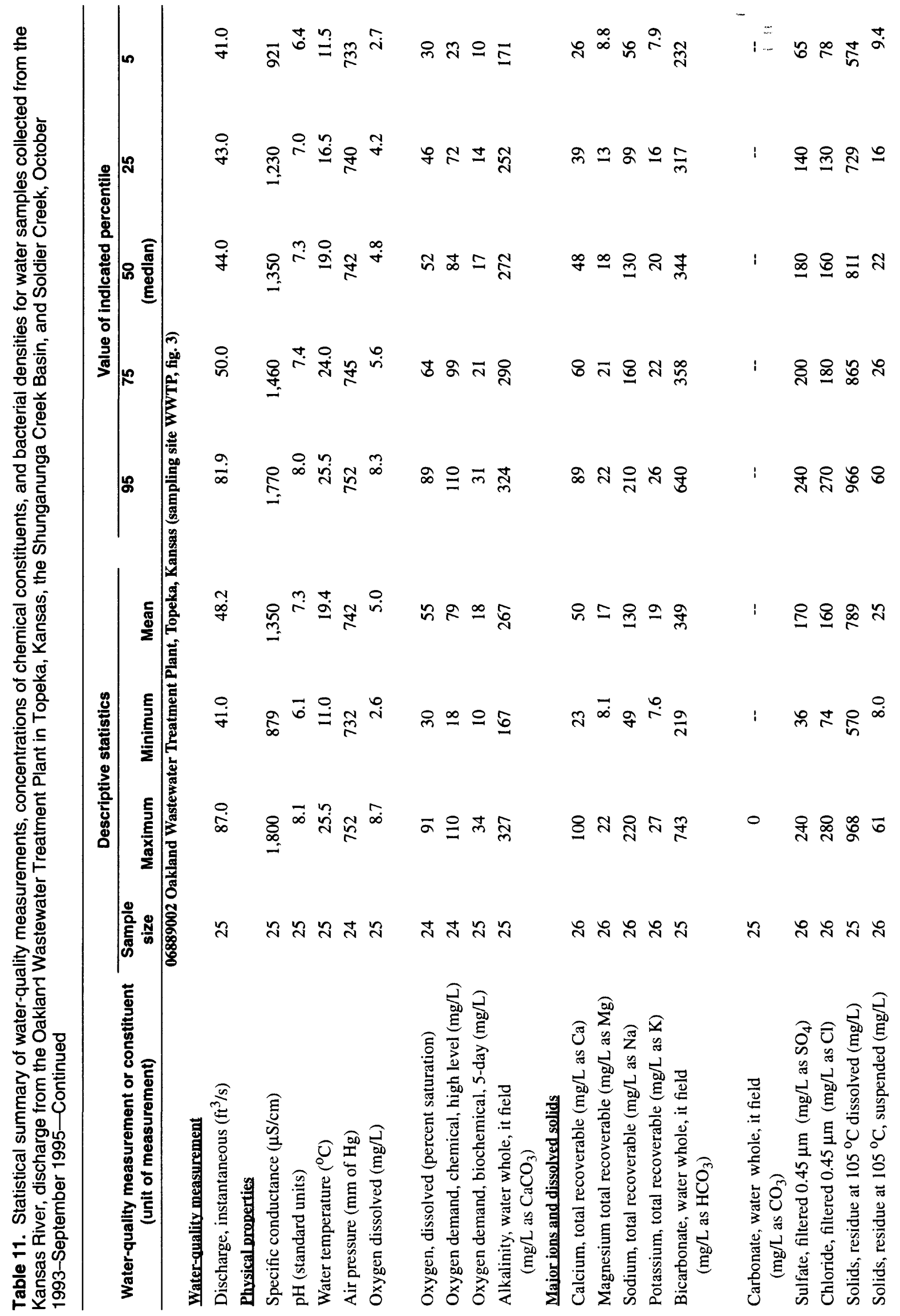




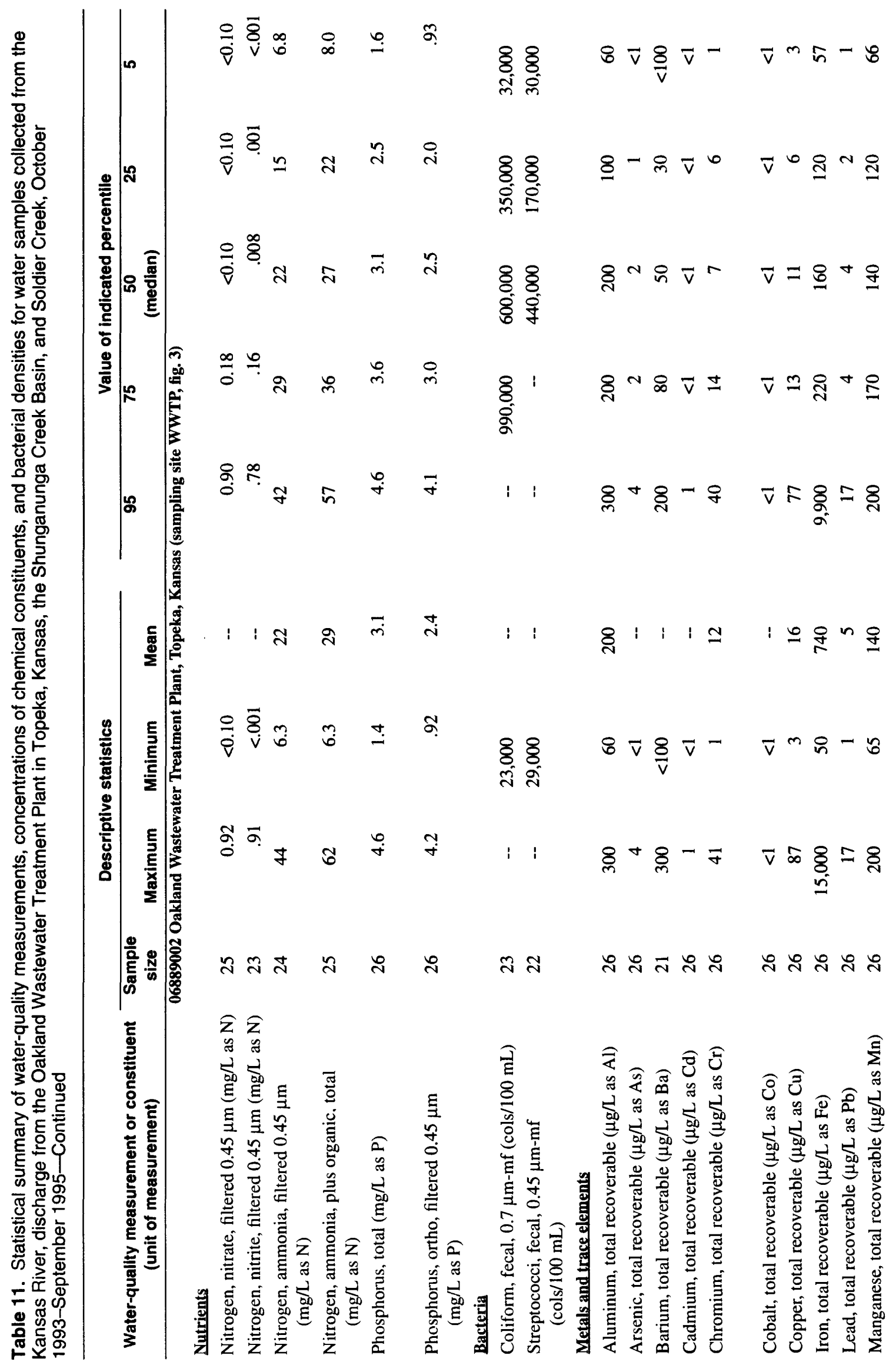

58 Effects of Urbanization on Water Quality in the Kansas River, Shunganunga Creek Basin, and Soidier Creek, Topeka, Kansas, October 1993 Through September 1995 


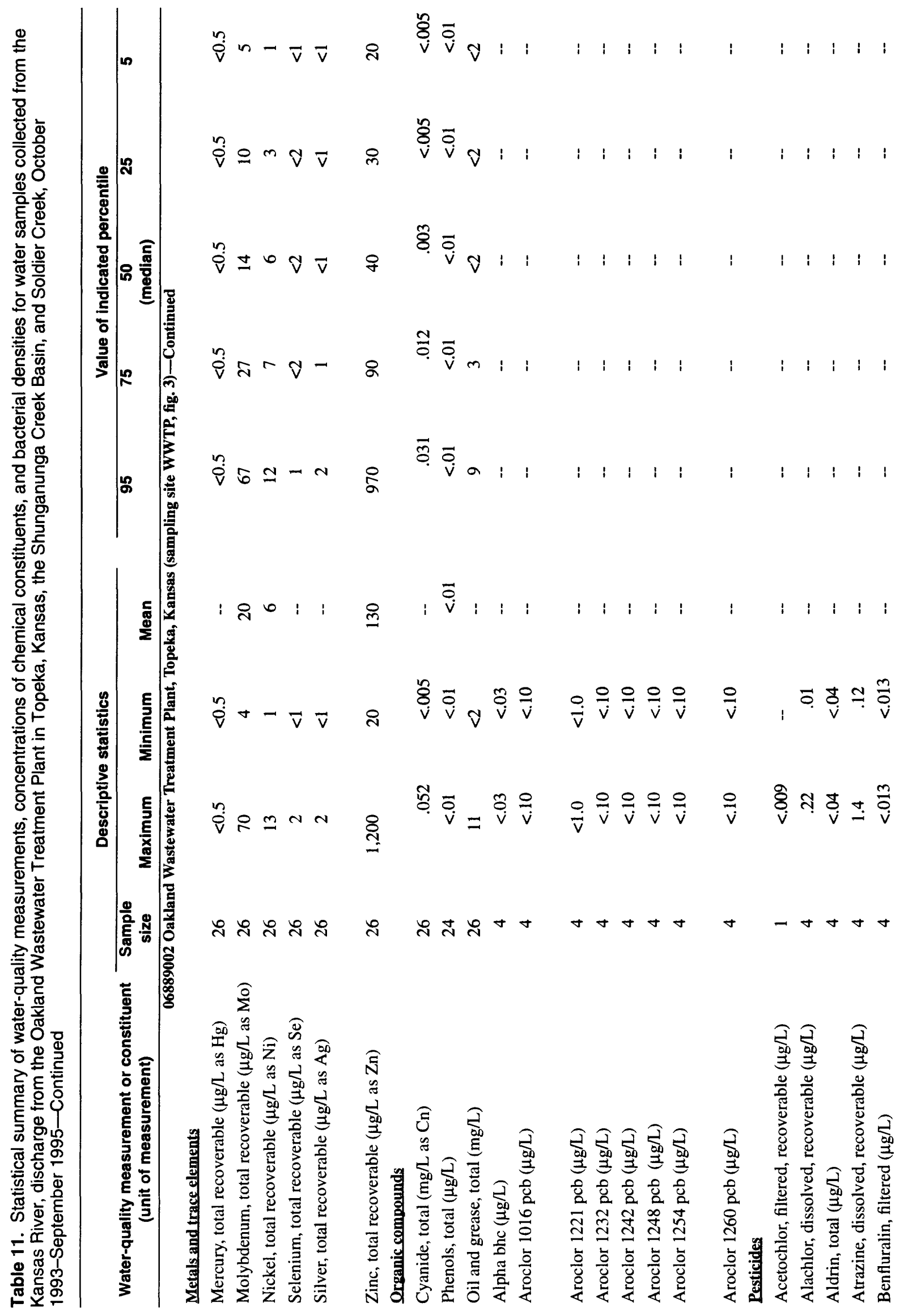




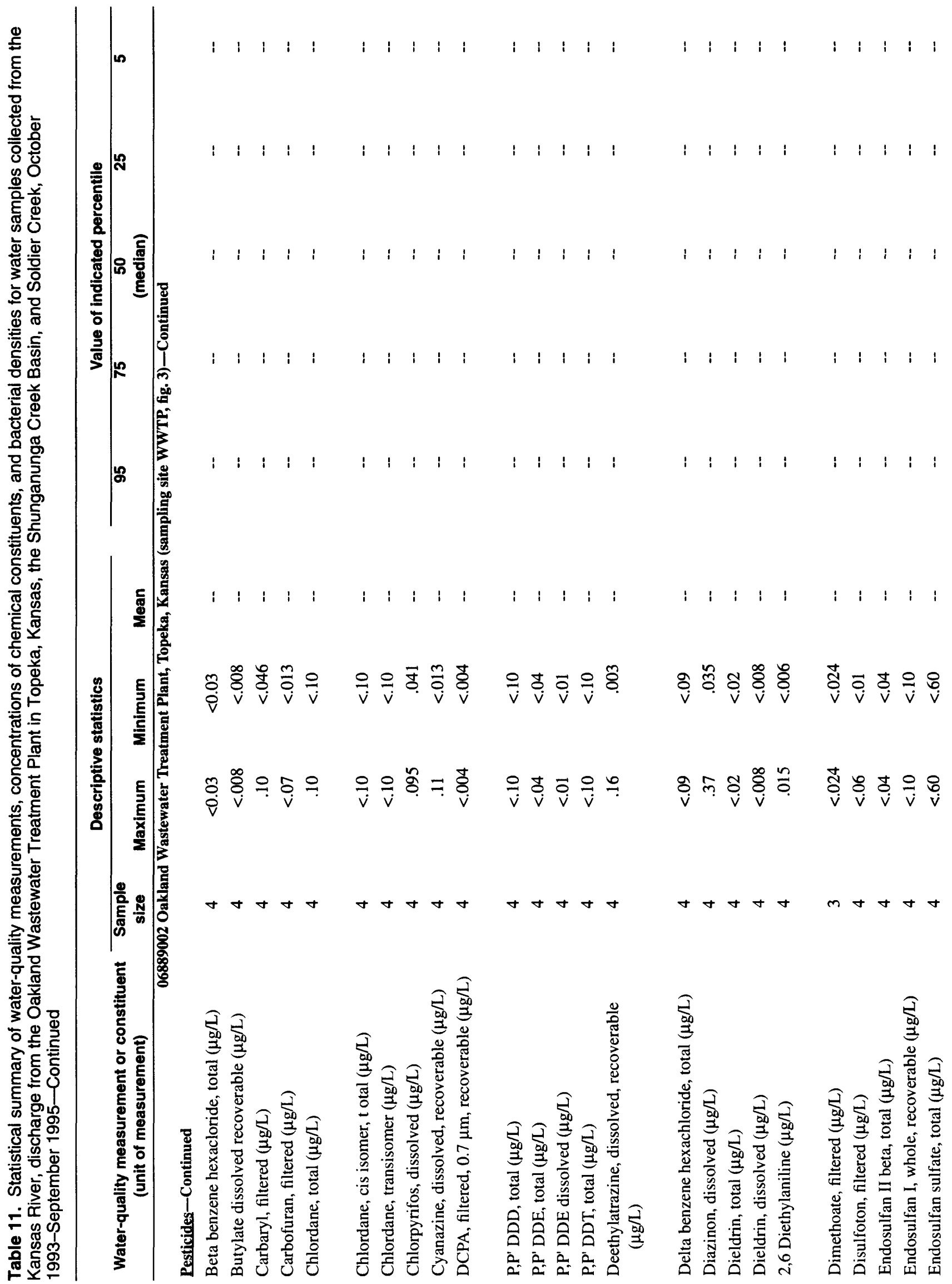

60 Effects of Urbanization on Water Quality in the Kansas River, Shunganunga Creek Basin, and Soldier Creek, Topeka, Kansas, October 1993 Through September 1995 


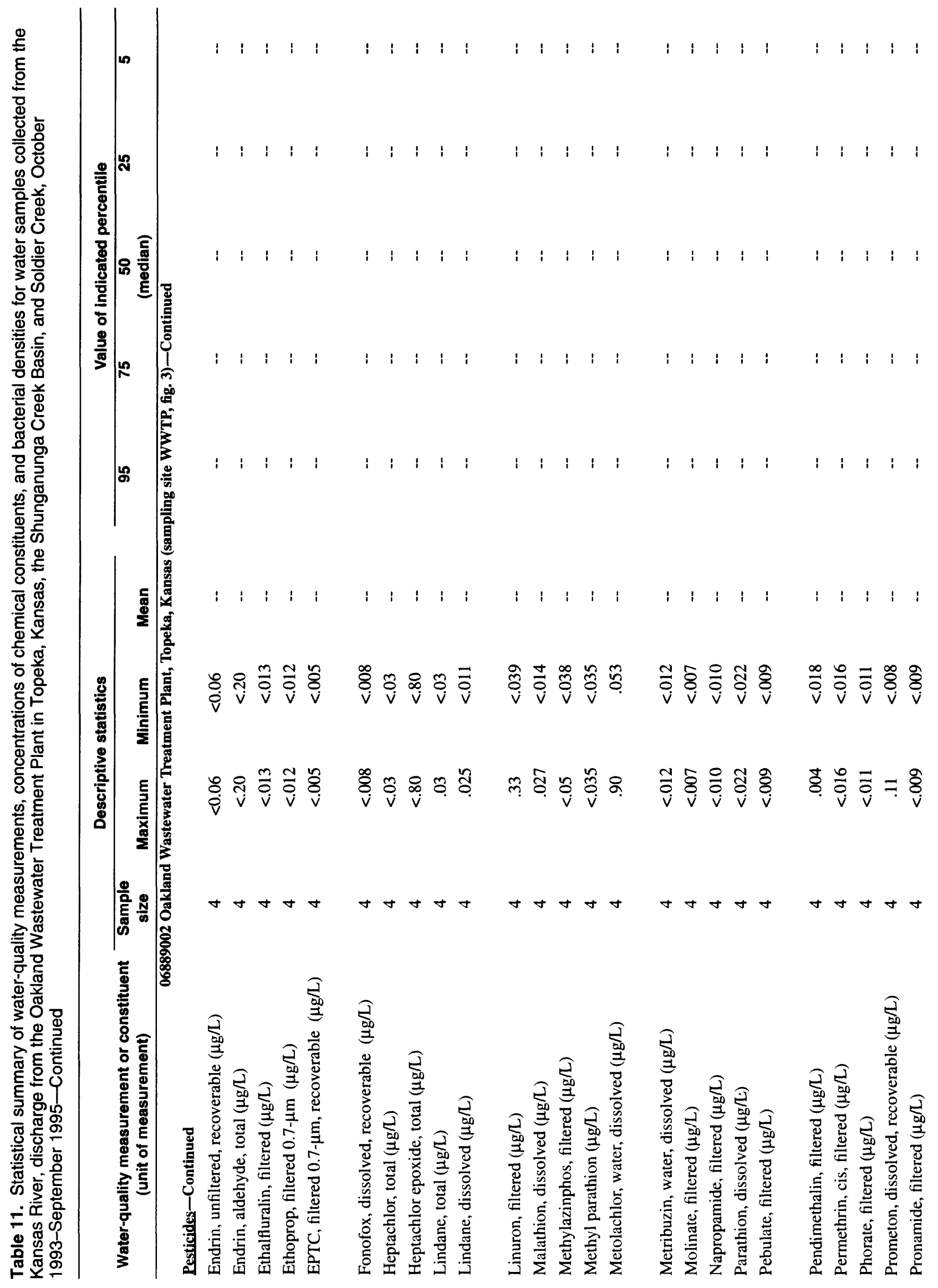




$$
\begin{aligned}
& \stackrel{\infty}{\circ} \text { 유율 }
\end{aligned}
$$

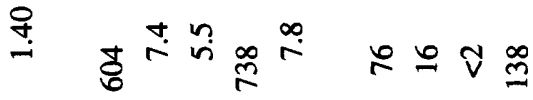

$$
\begin{aligned}
& \text { \& } \\
& \text { ल } \\
& \text { 焉 }
\end{aligned}
$$

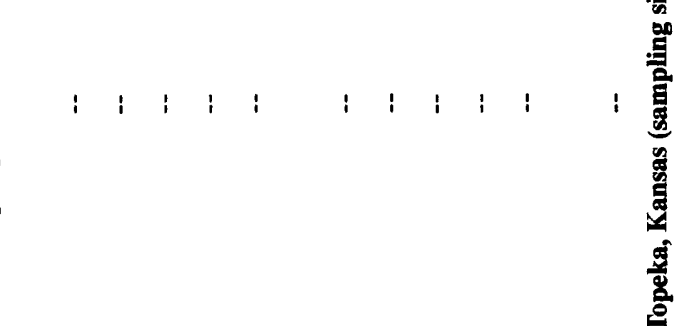

$$
\begin{aligned}
& \begin{array}{llllllllll}
1 & 1 & 1 & 1 & 1 & 1 & 1 & 1 & 1 & 1 \\
\hline
\end{array}
\end{aligned}
$$

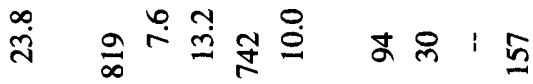

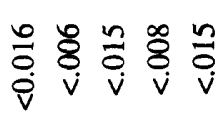

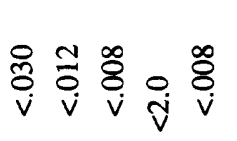

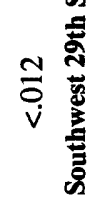

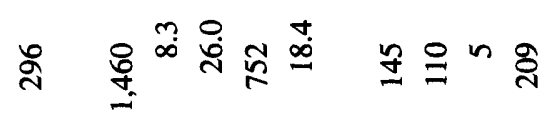

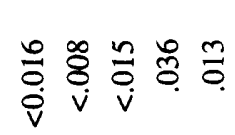

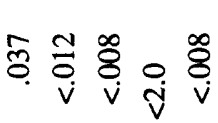

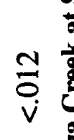

$$
\begin{aligned}
& \text { œ }
\end{aligned}
$$

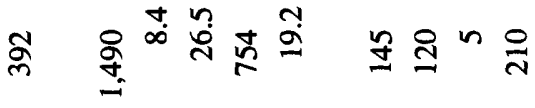

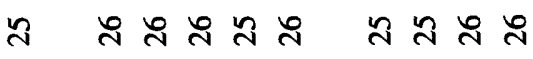

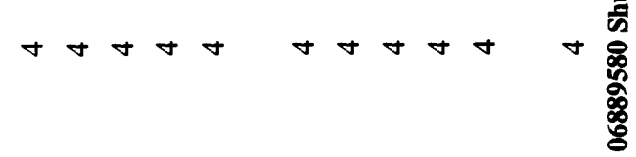

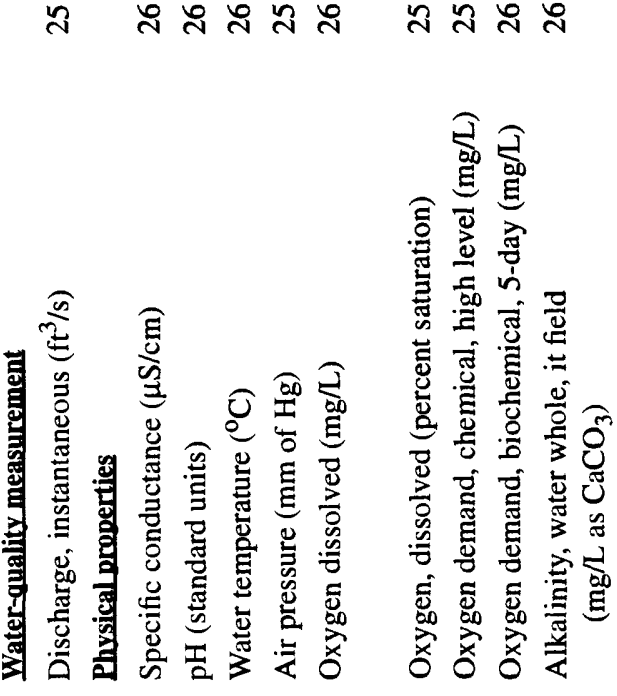

62 Effects of Urbanization on Water Quality in the Kansas River, Shunganunga Creek Basin, and Soldier Creek, Topeka, Kansas, 


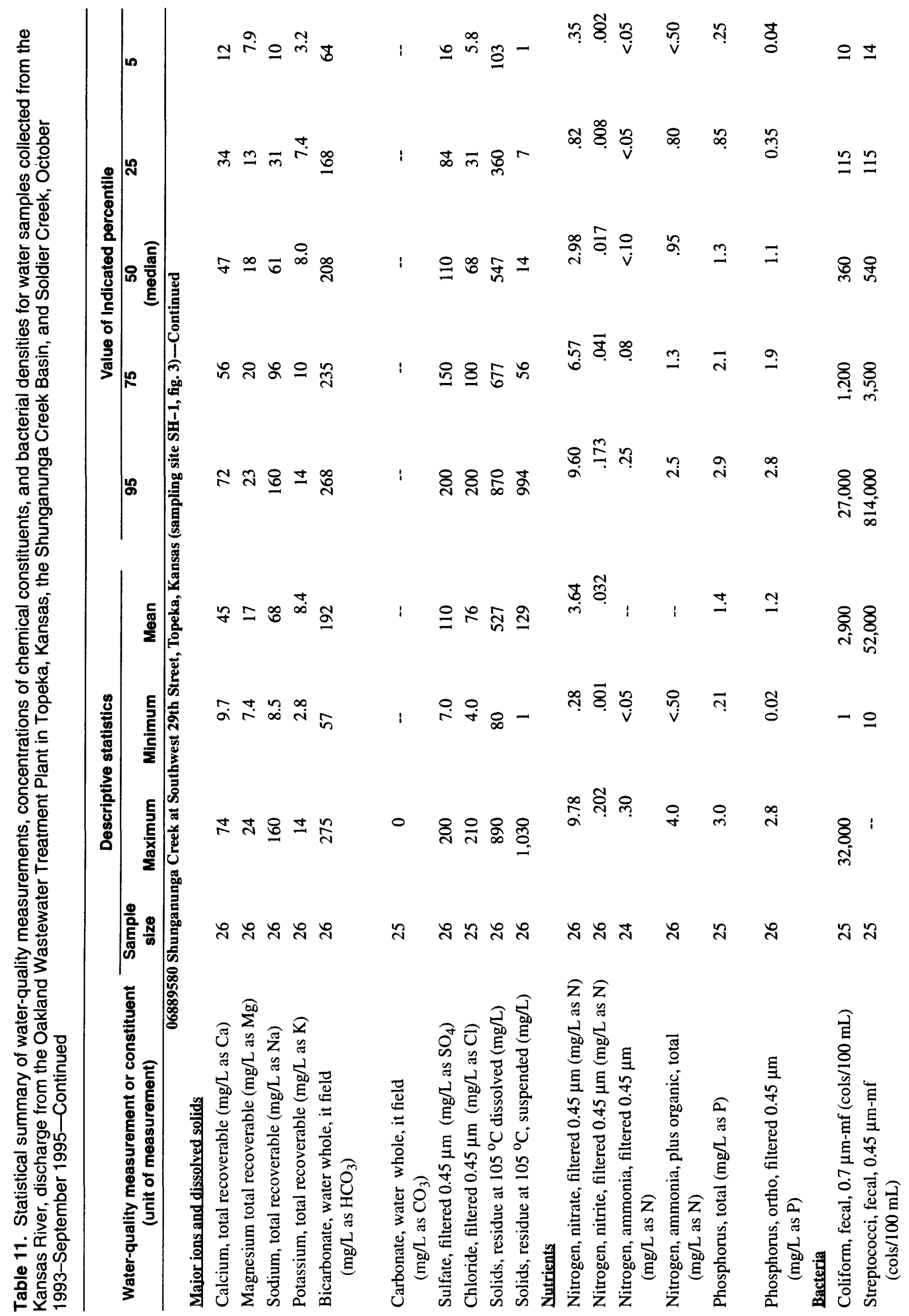




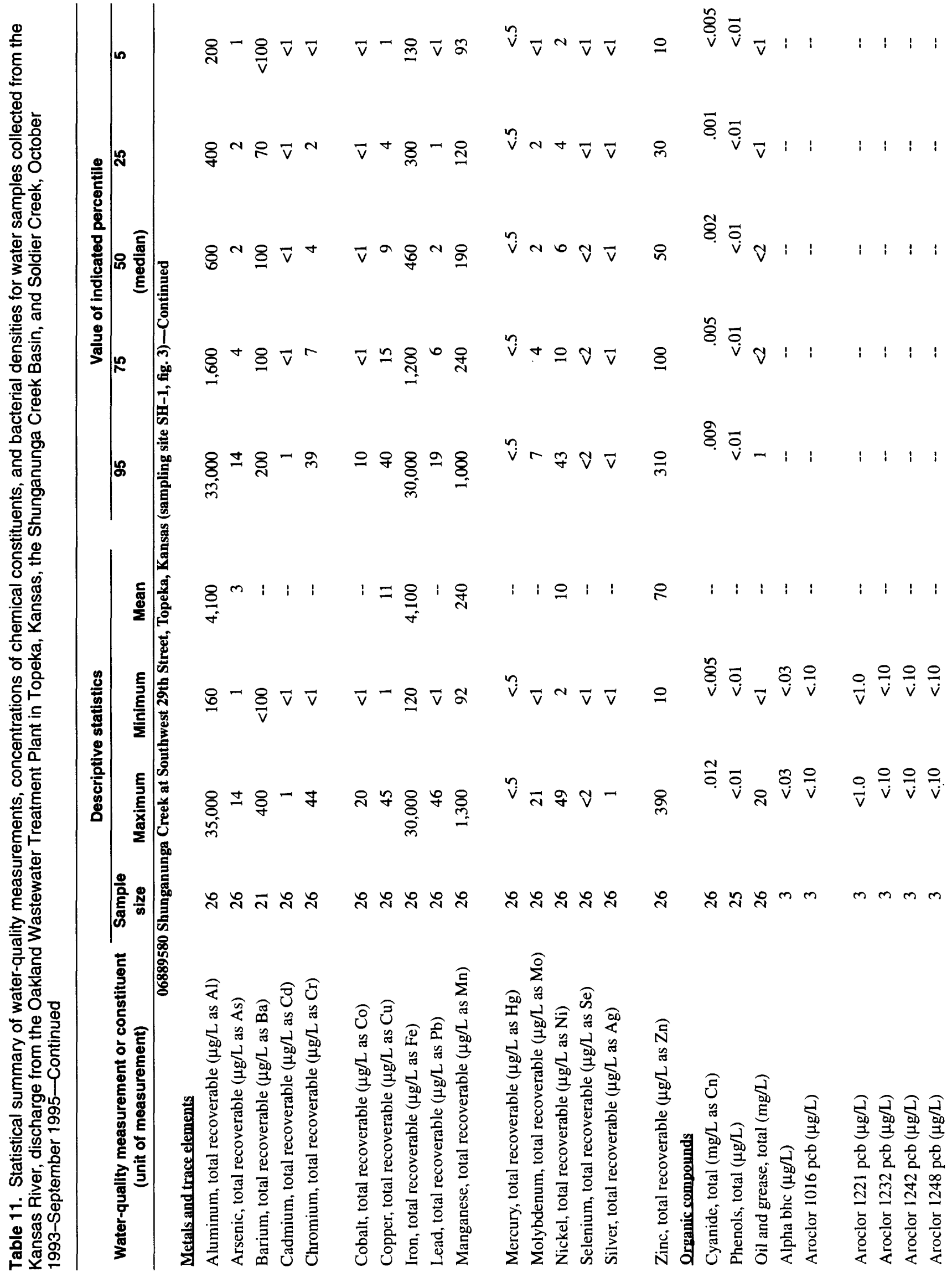

64 Effects of Urbanization on Water Quality in the Kansas River, Shunganunga Creek Basin, and Soldier Creek, Topeka, Kansas, October 1993 Through September 1995 


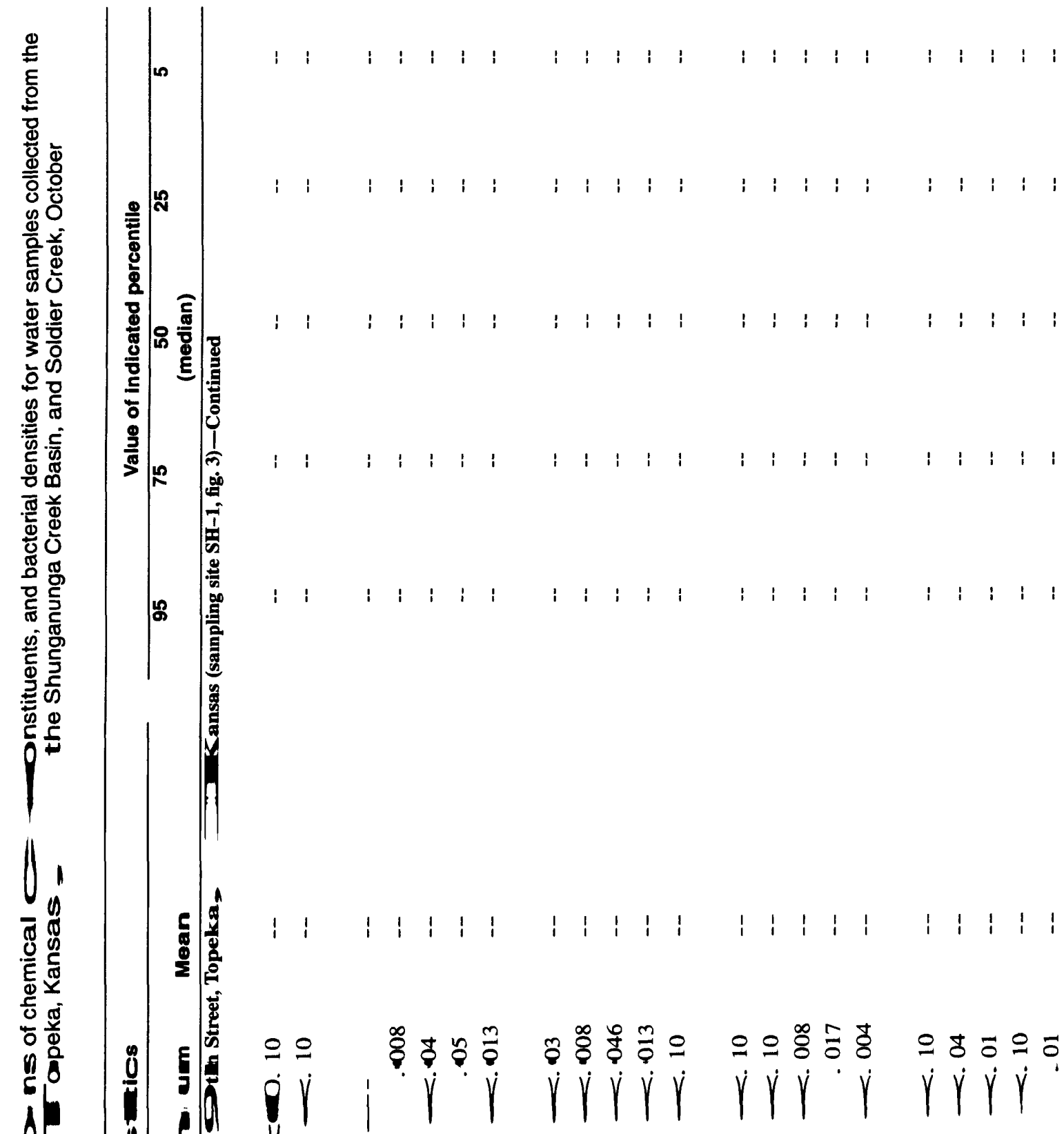



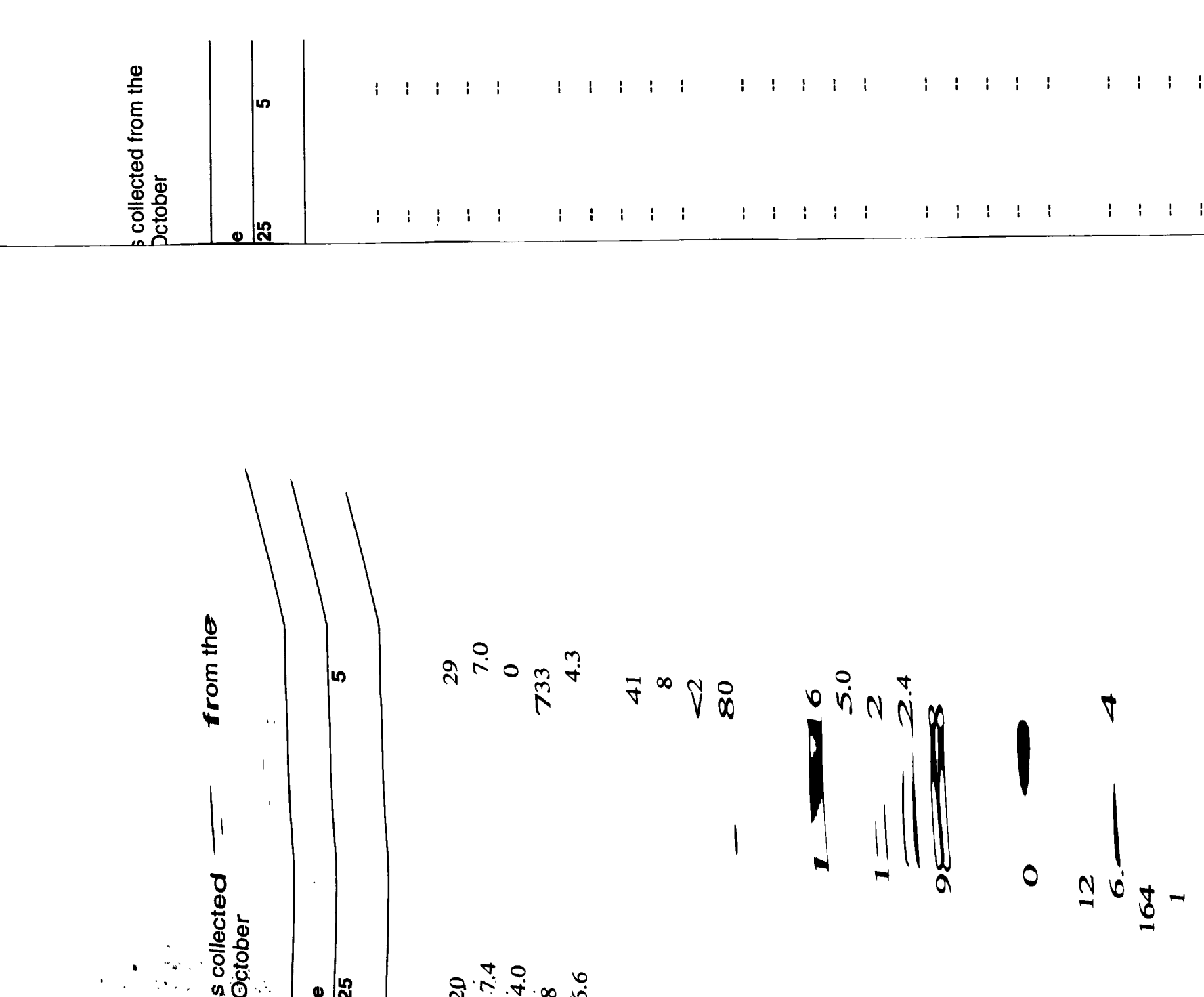

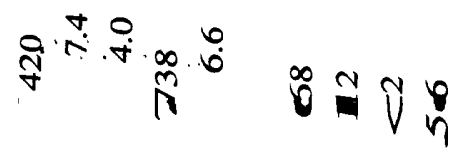

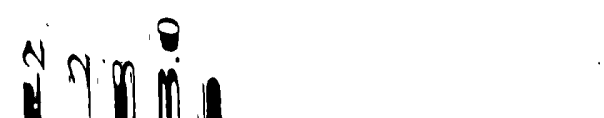




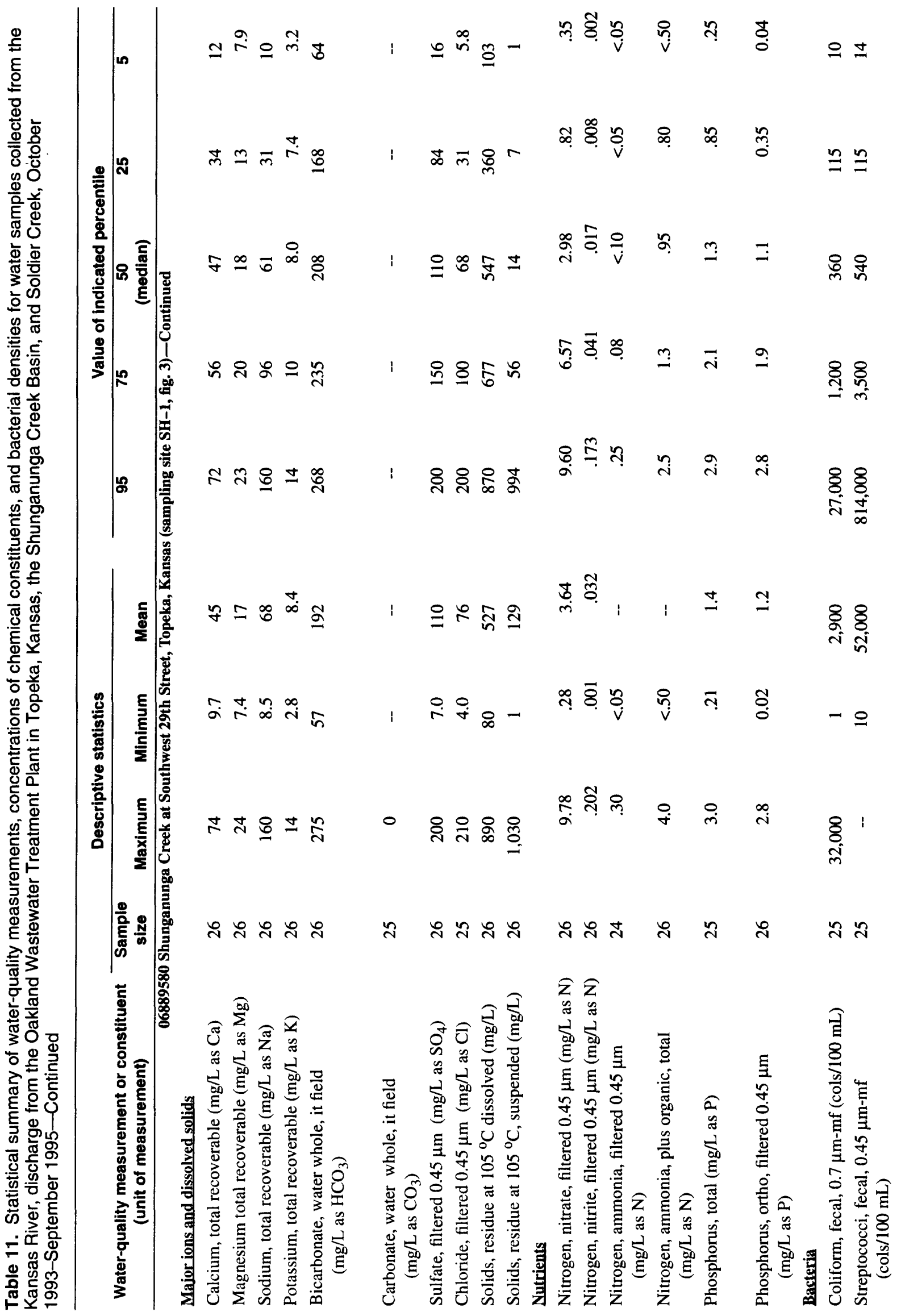




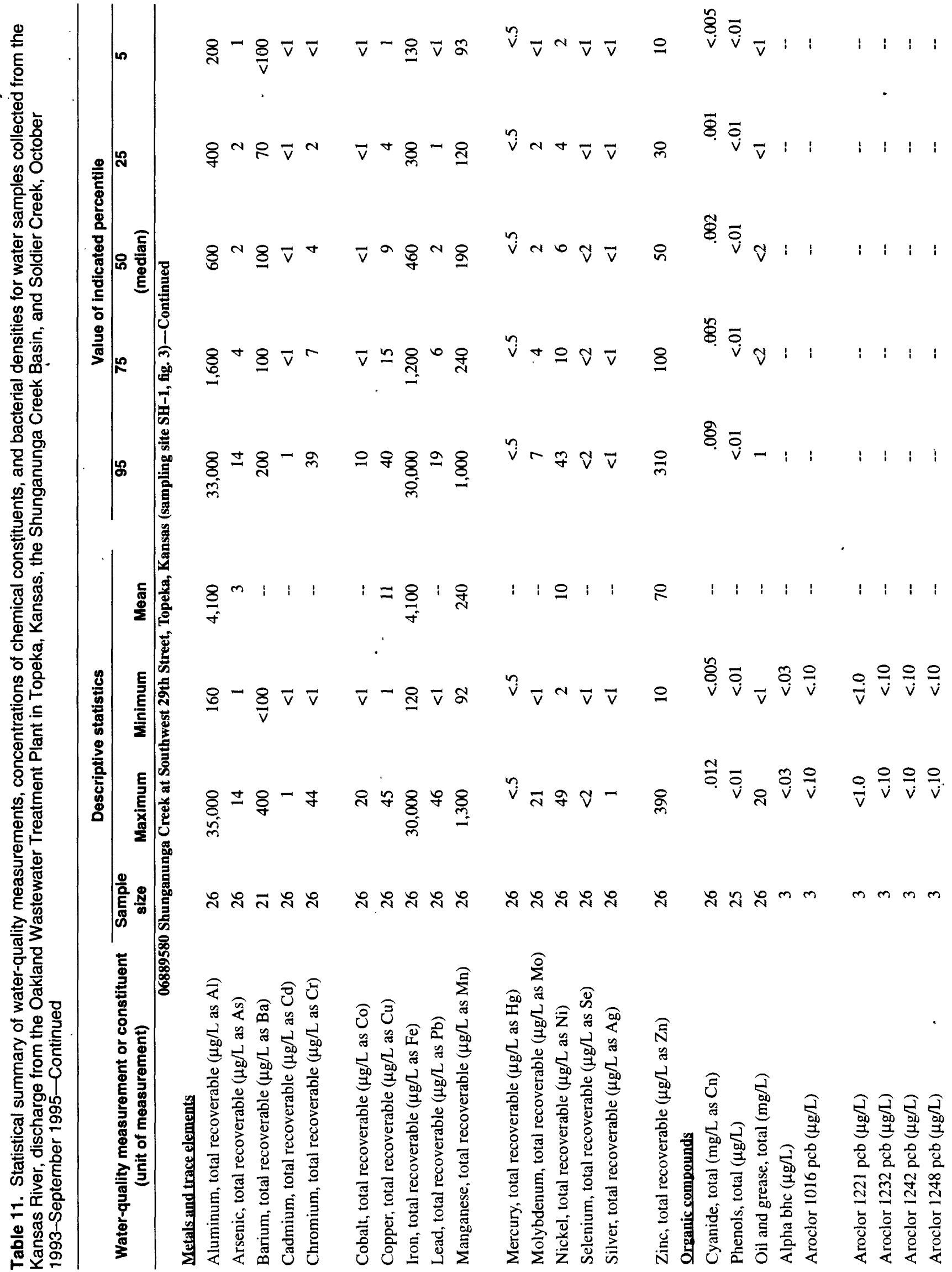

64 Effects of Urbanization on Water Quality in the Kansas River, Shunganunga Creek Basin, and Soldier Creek, Topeka, Kansas, October 1993 Through September 1995 


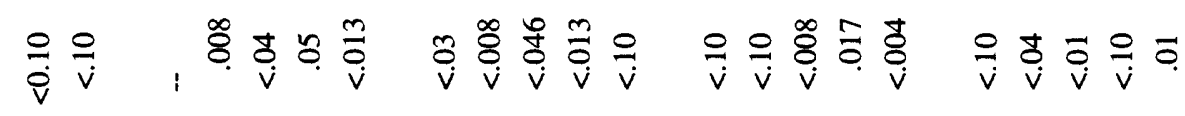

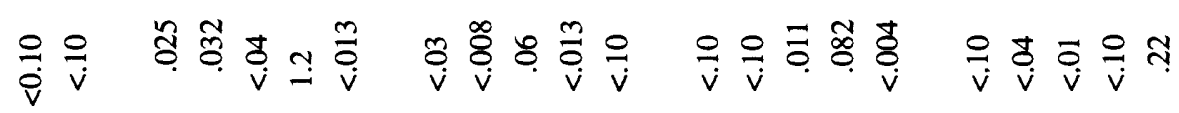

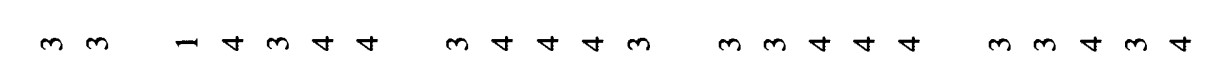

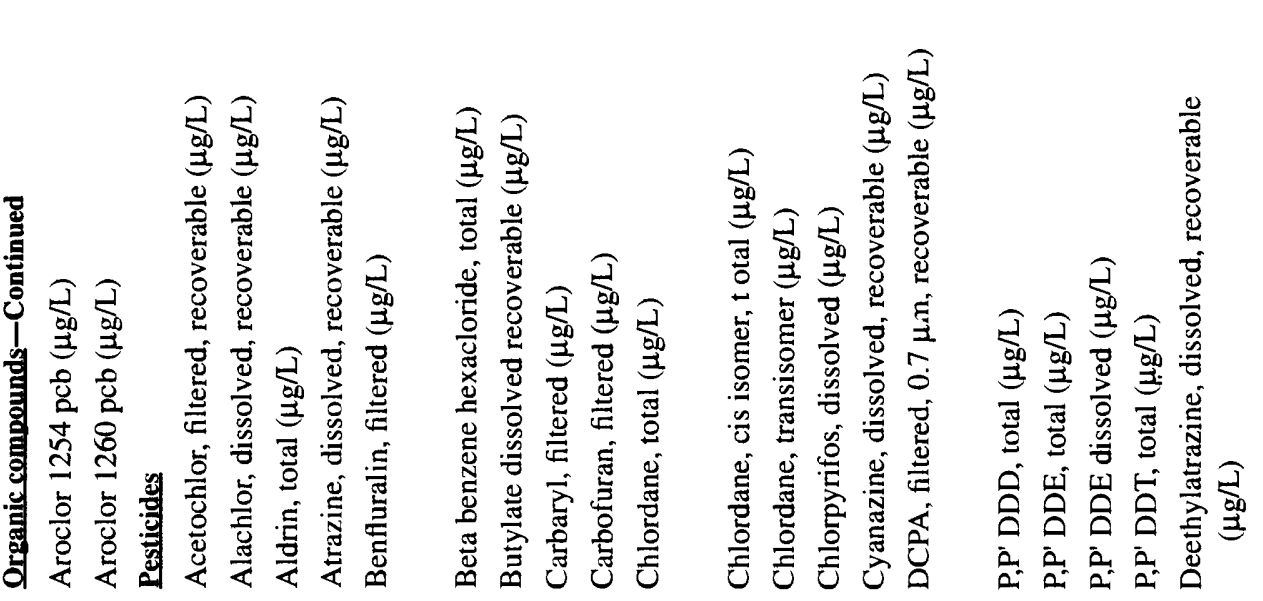


志

\&

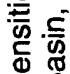

욤

중

ธั

苋

등

s。

$\stackrel{\infty}{\stackrel{0}{0}}$

क्षै

ธั

焉

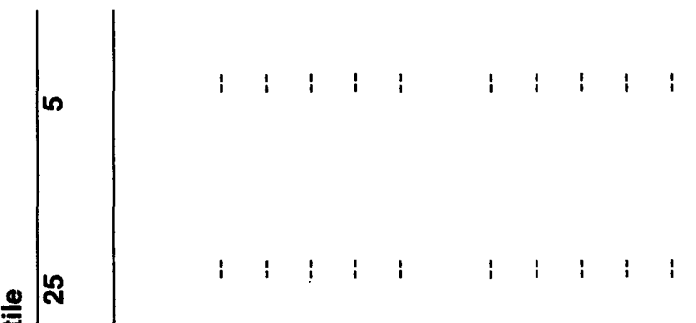




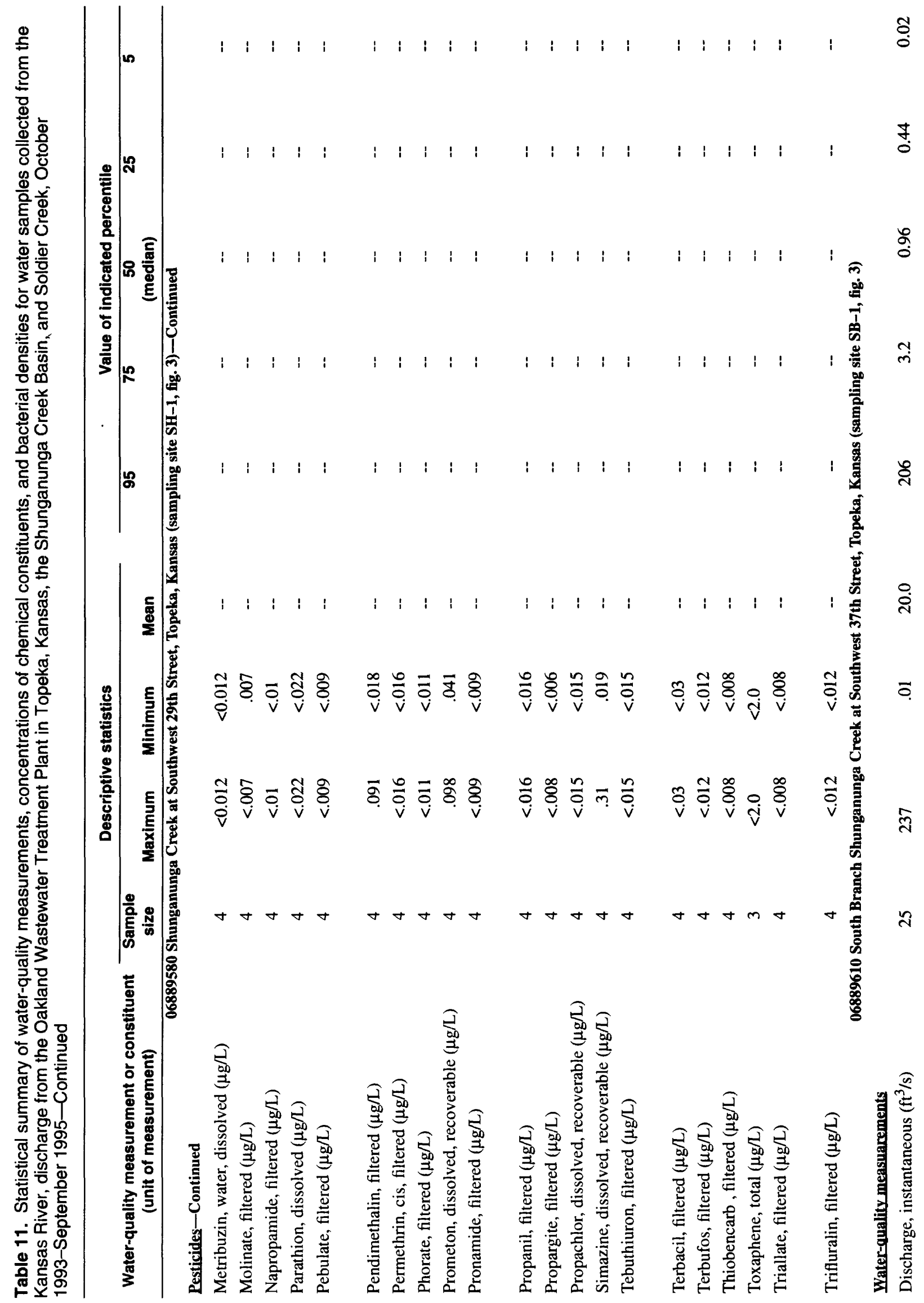




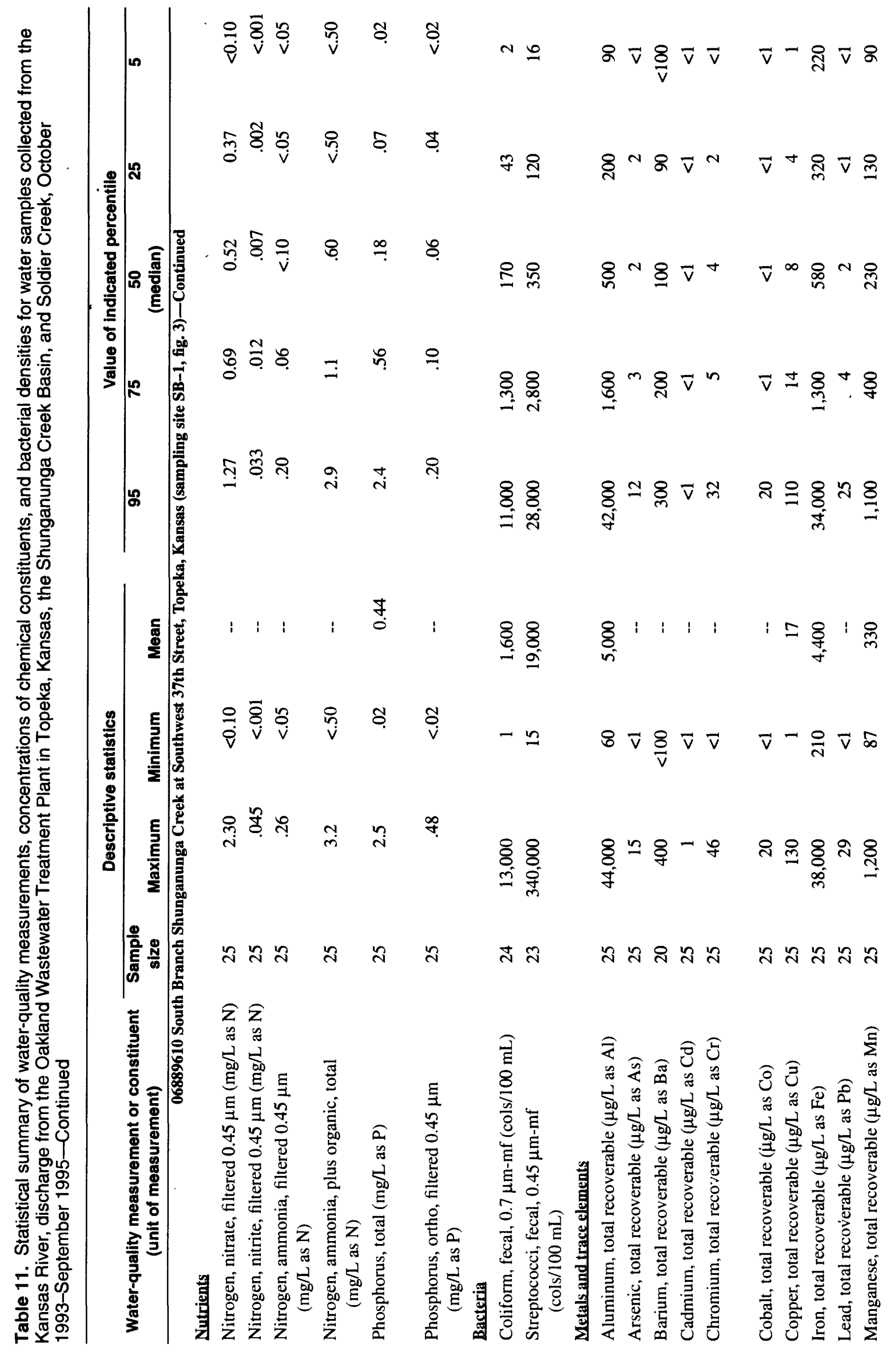




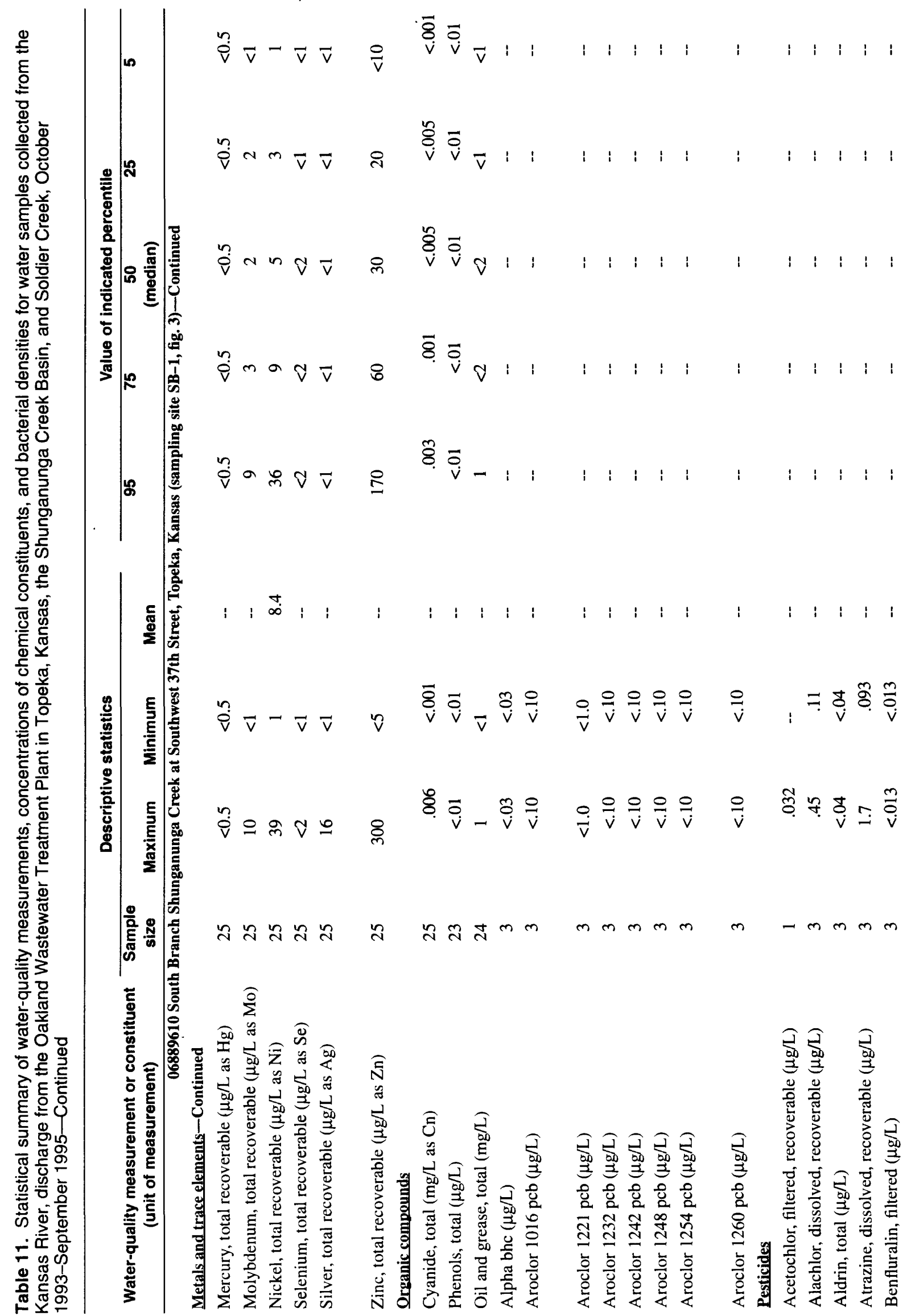

70 Effects of Urbanization on Water Quality in the Kansas River, Shunganunga Creek Basin, and Soidier Creek, Topeka, Kansas, October 1993 Through September 1995 


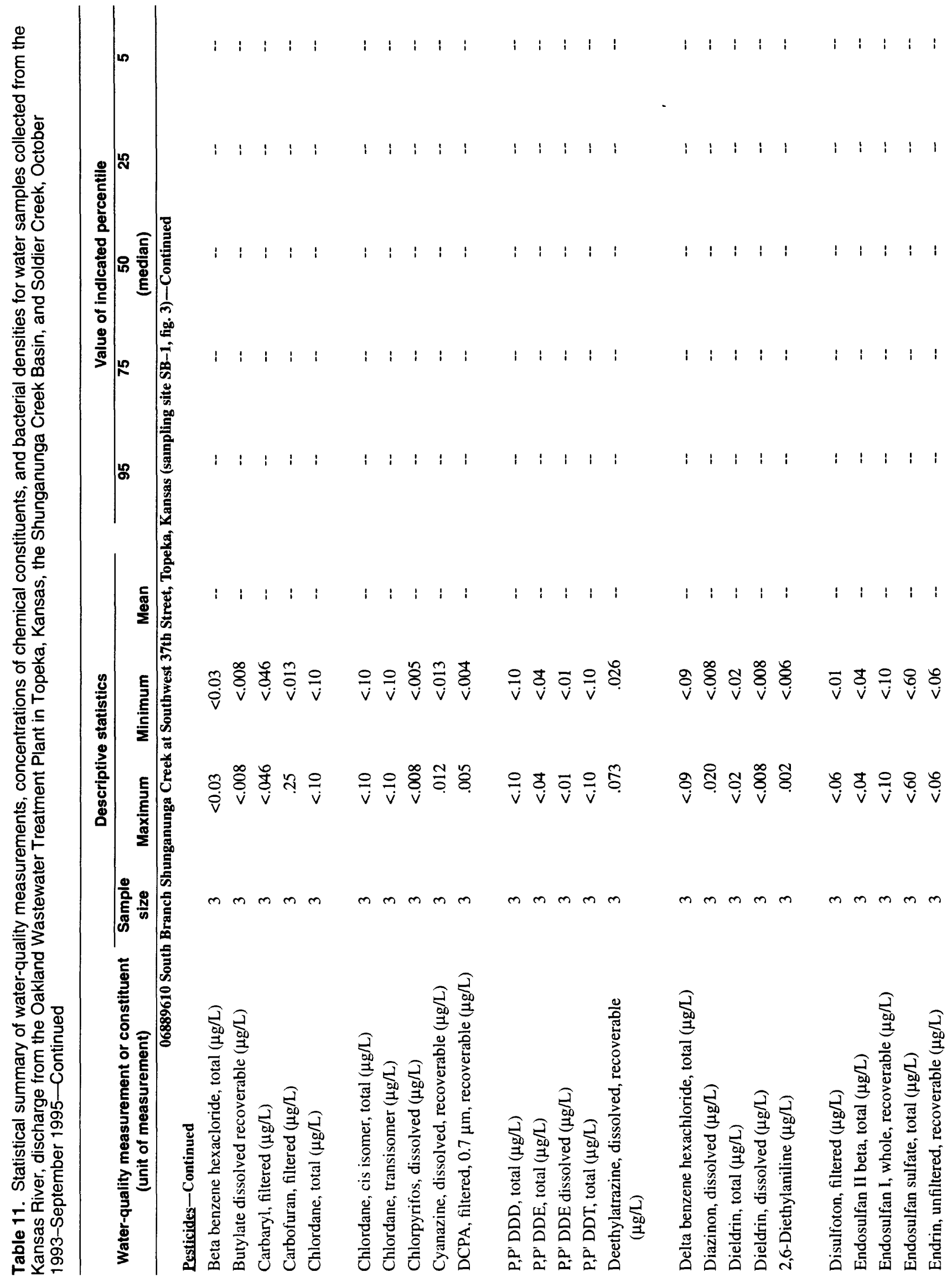




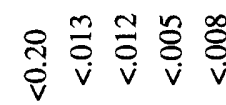

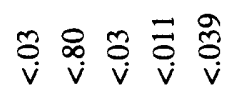

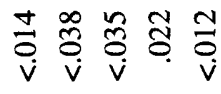

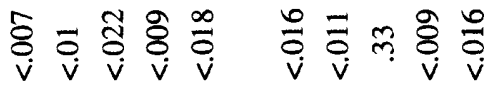

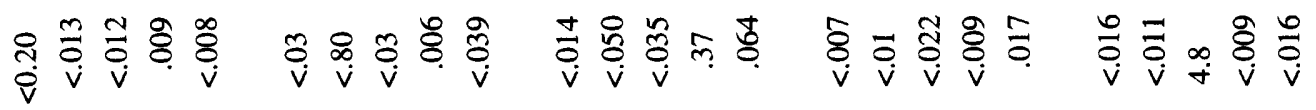

mmmm mmmm

$m m m m$

$\mathrm{mmmm}$

$m m m m$

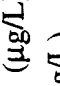

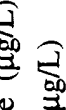

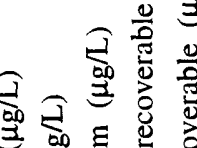

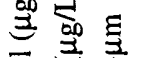

उ

I

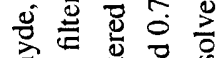

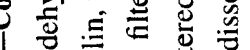

เ

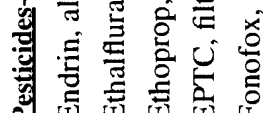
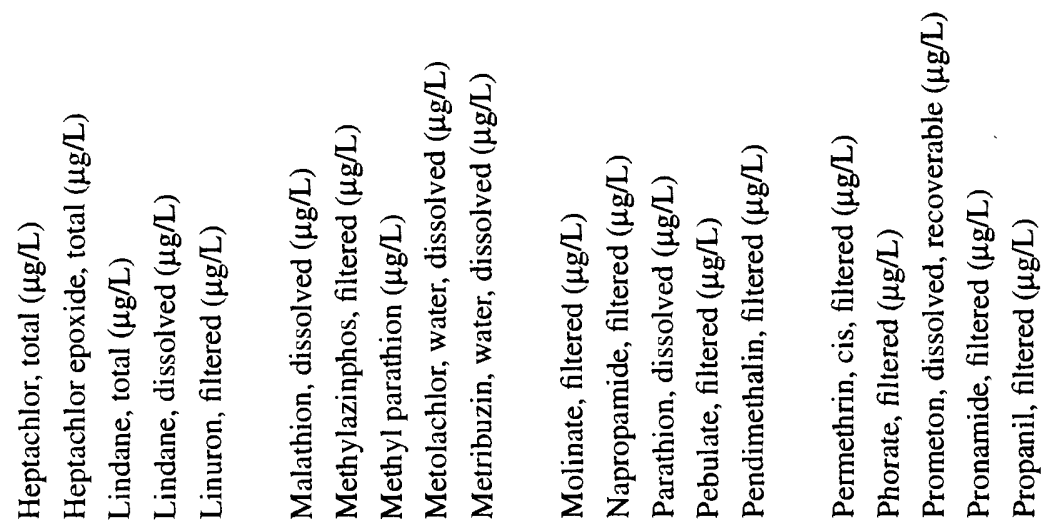

72

Effects of Urbanization on Water Quality

October 1993 Through September 1995 


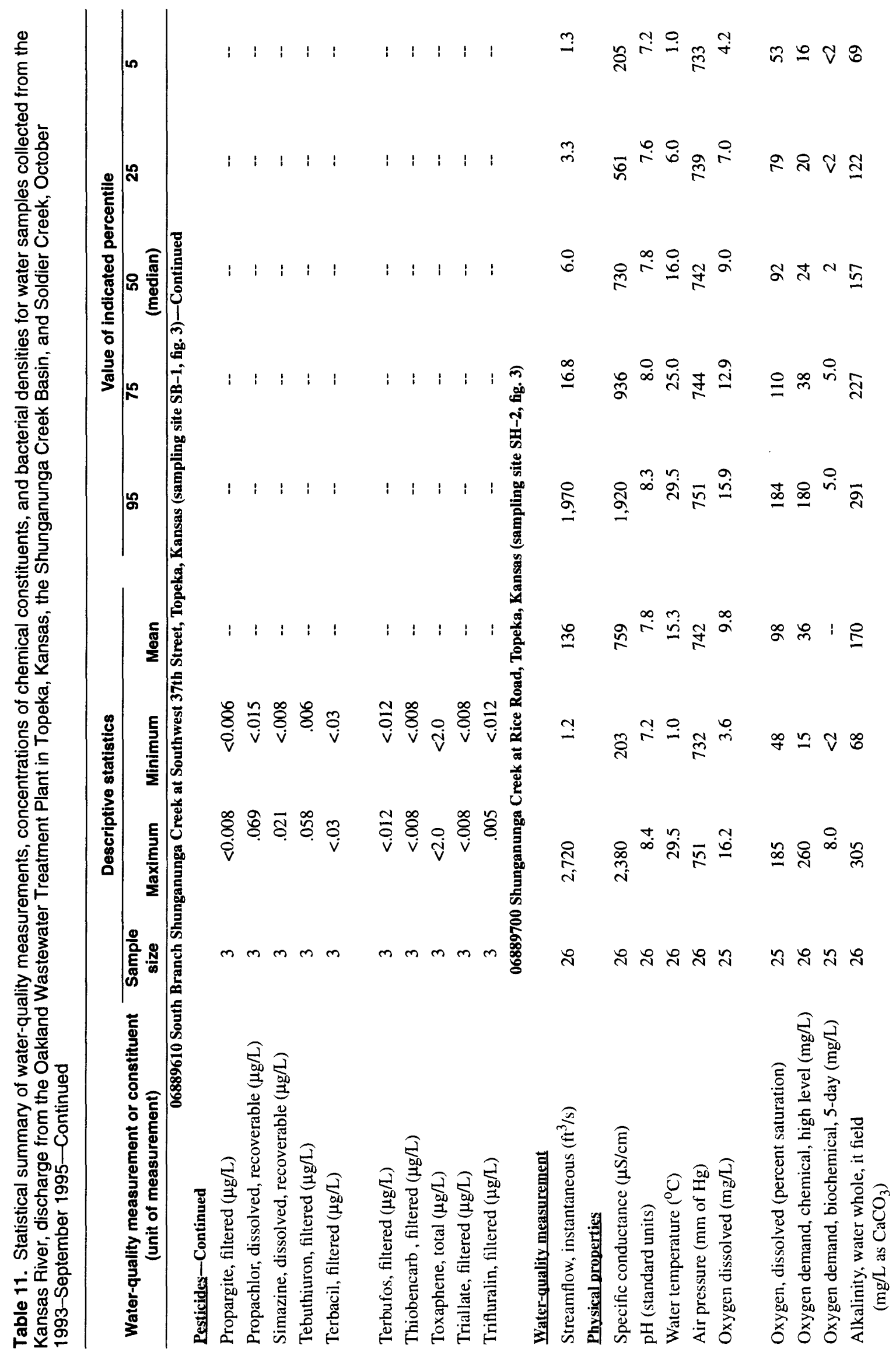




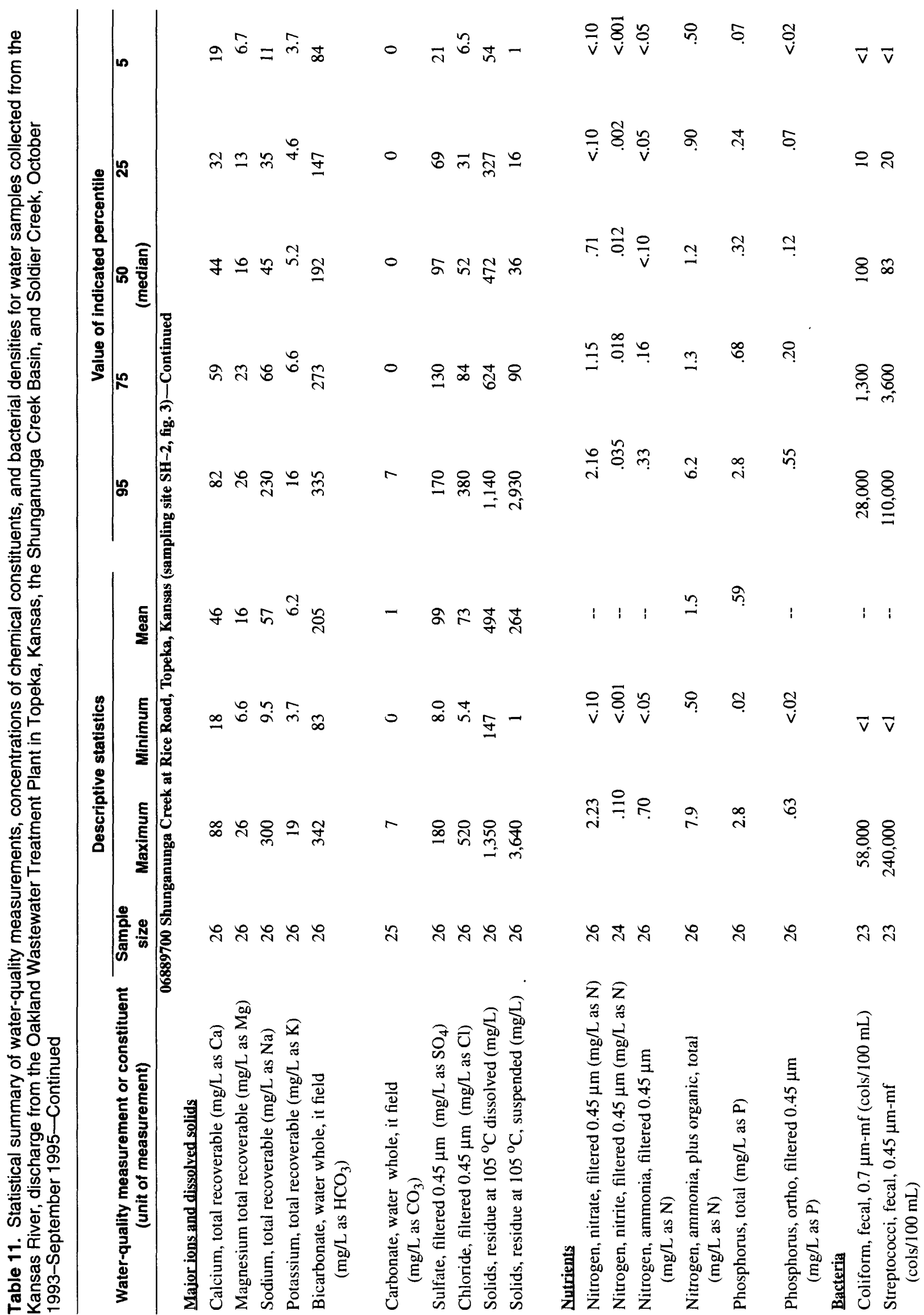

74 Effects of Urbanization on Water Quality in the Kansas River, Shunganunga Creek Basin, and Soldier Creek, Topeka, Kansas, October 1993 Through September 1995 


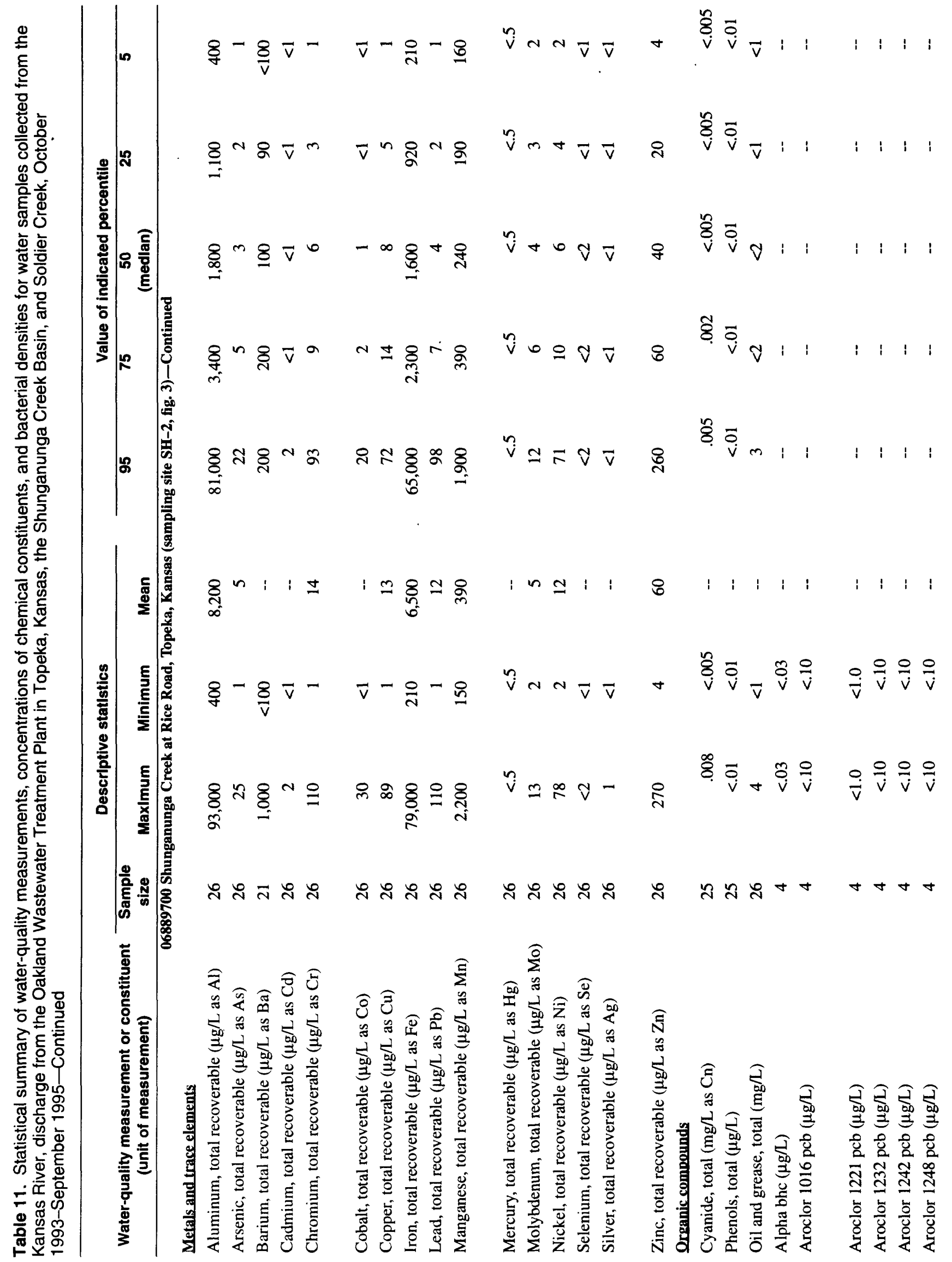




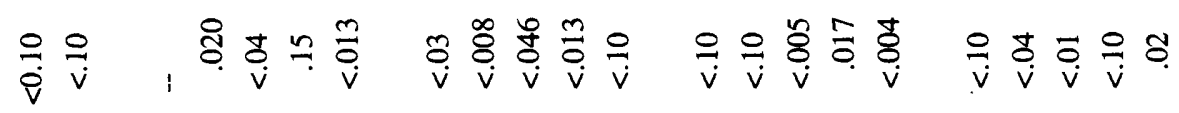

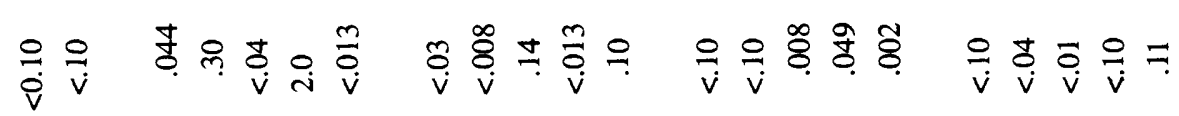

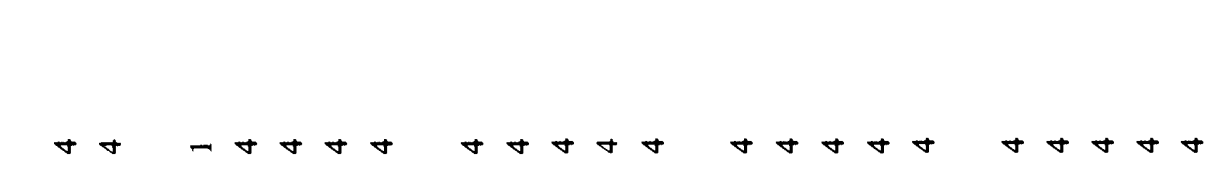

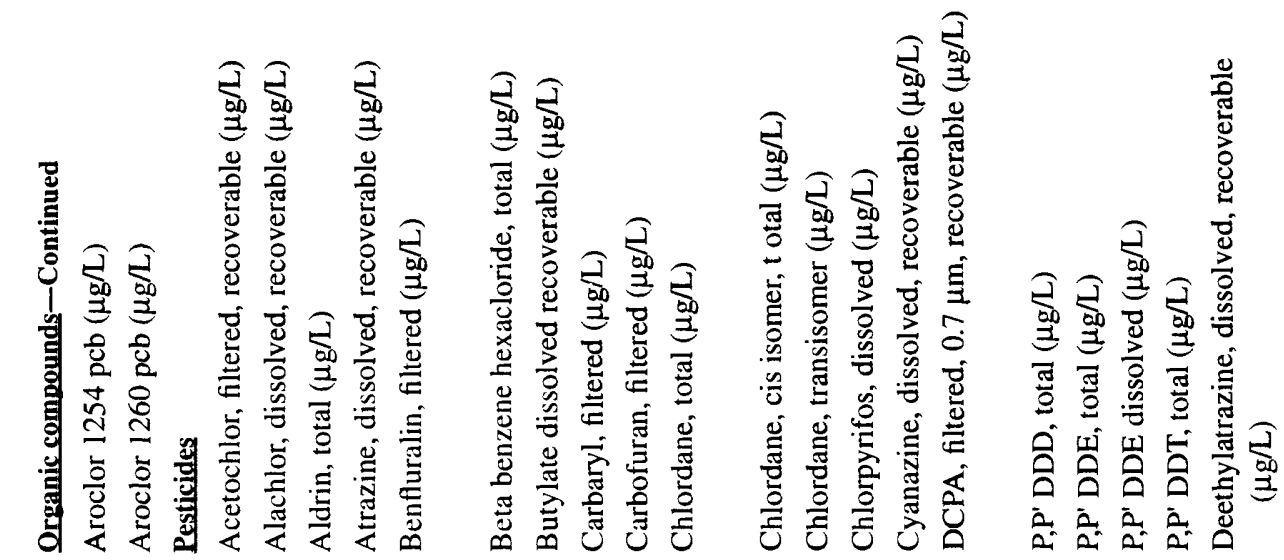

76 Effects of Urbanization on Water Quality in the Kansas River, Shunganunga Creek Basin, and Soldier Creek, Topeka, Kansas, October 1993 Through September 1995 


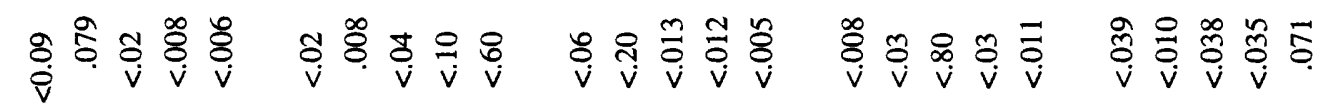

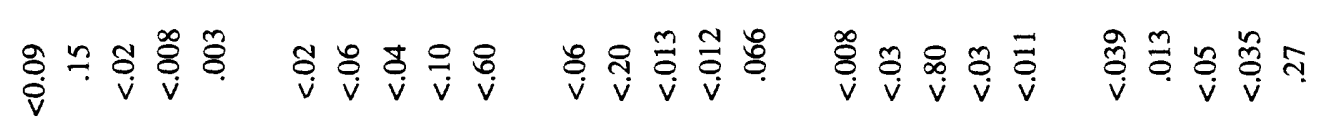
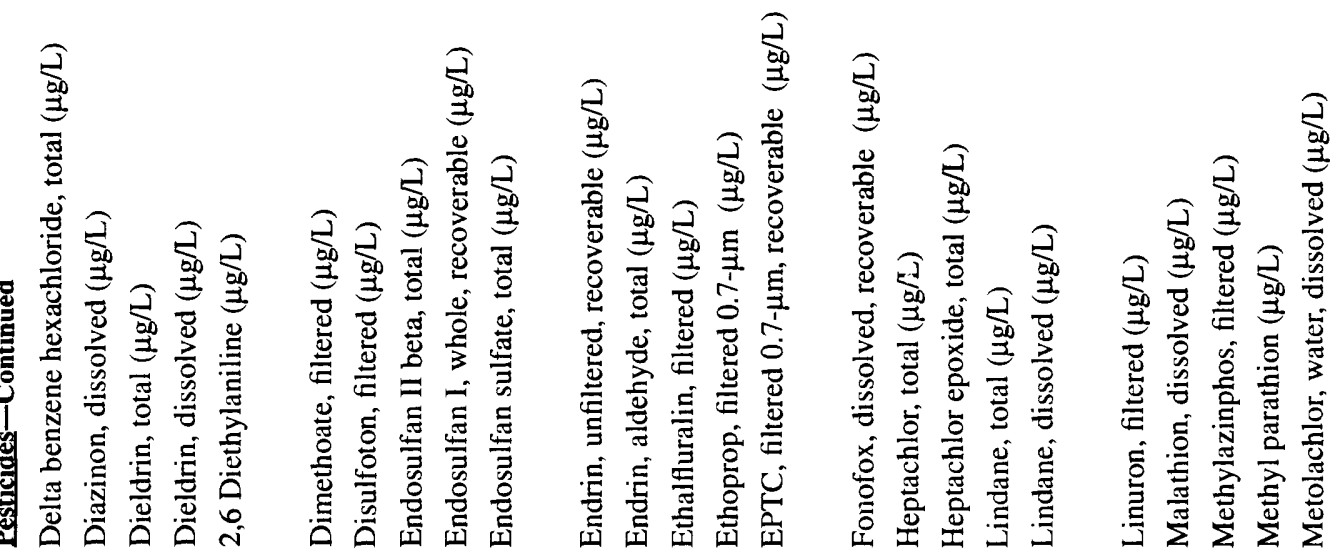


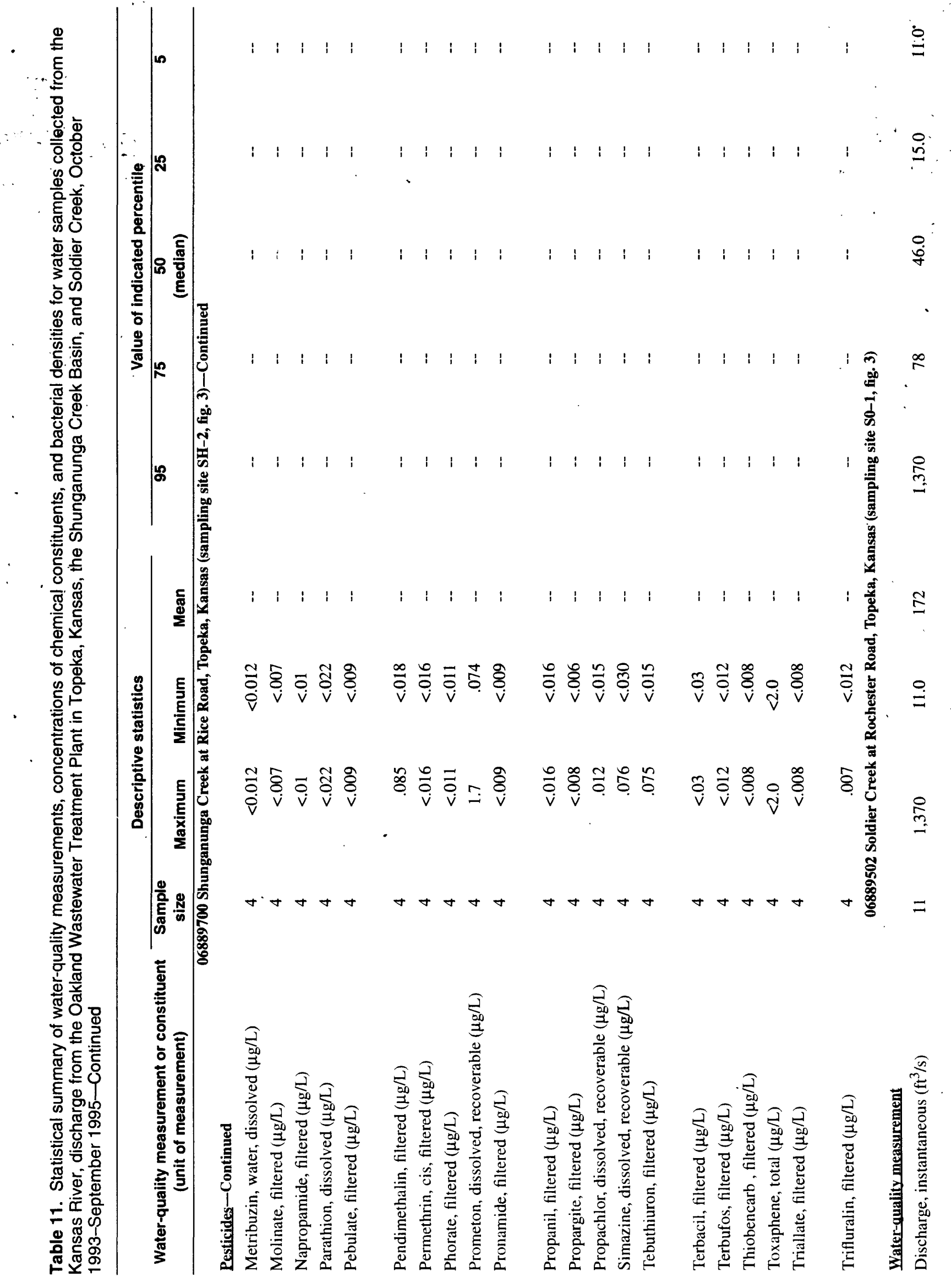

78 Effects of Urbanization on Water Quality in the Kansas River, Shunganunga Creek Basin, and Soldier Creek, Topeka, Kansas, October 1993 Through September 1995 


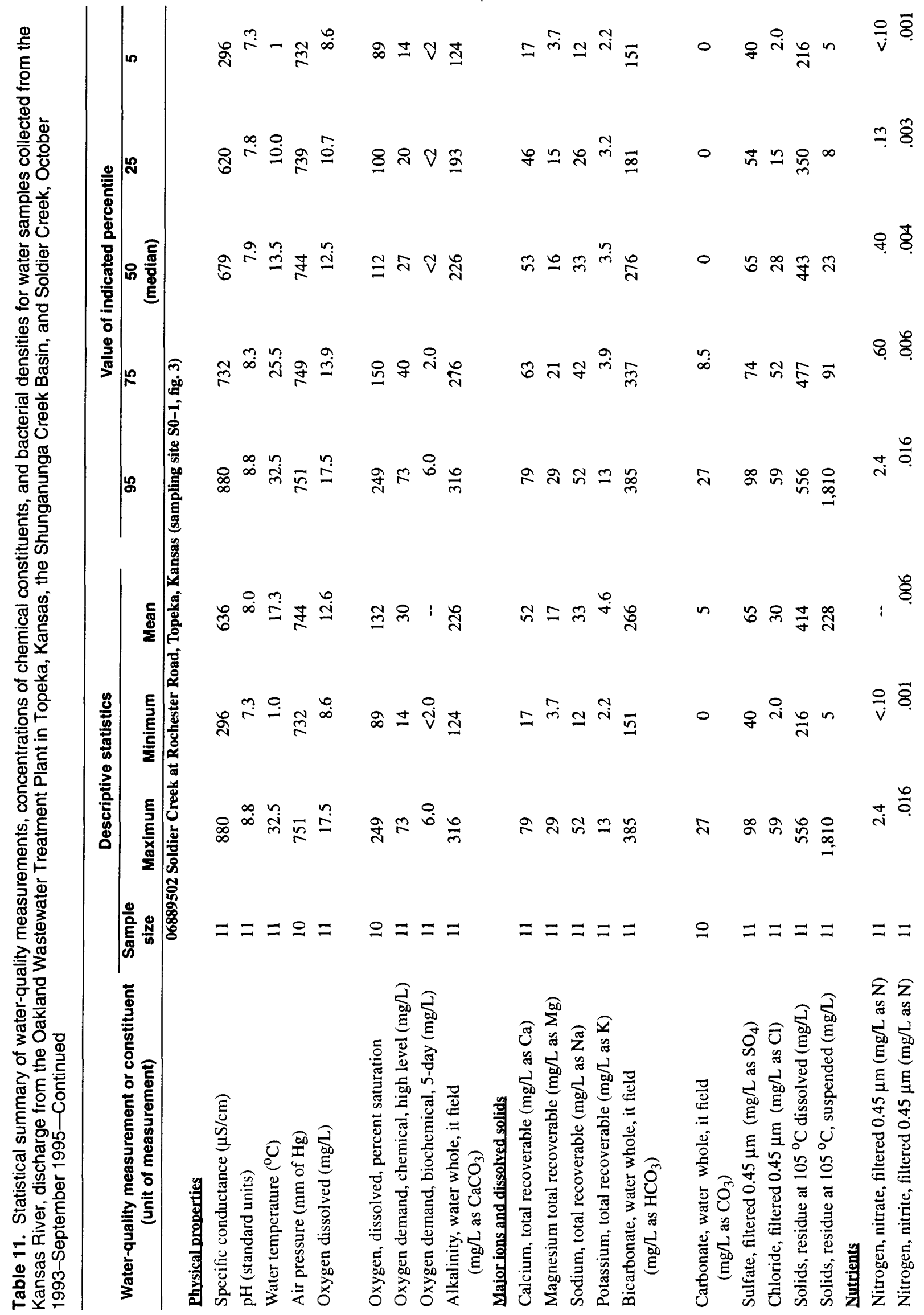




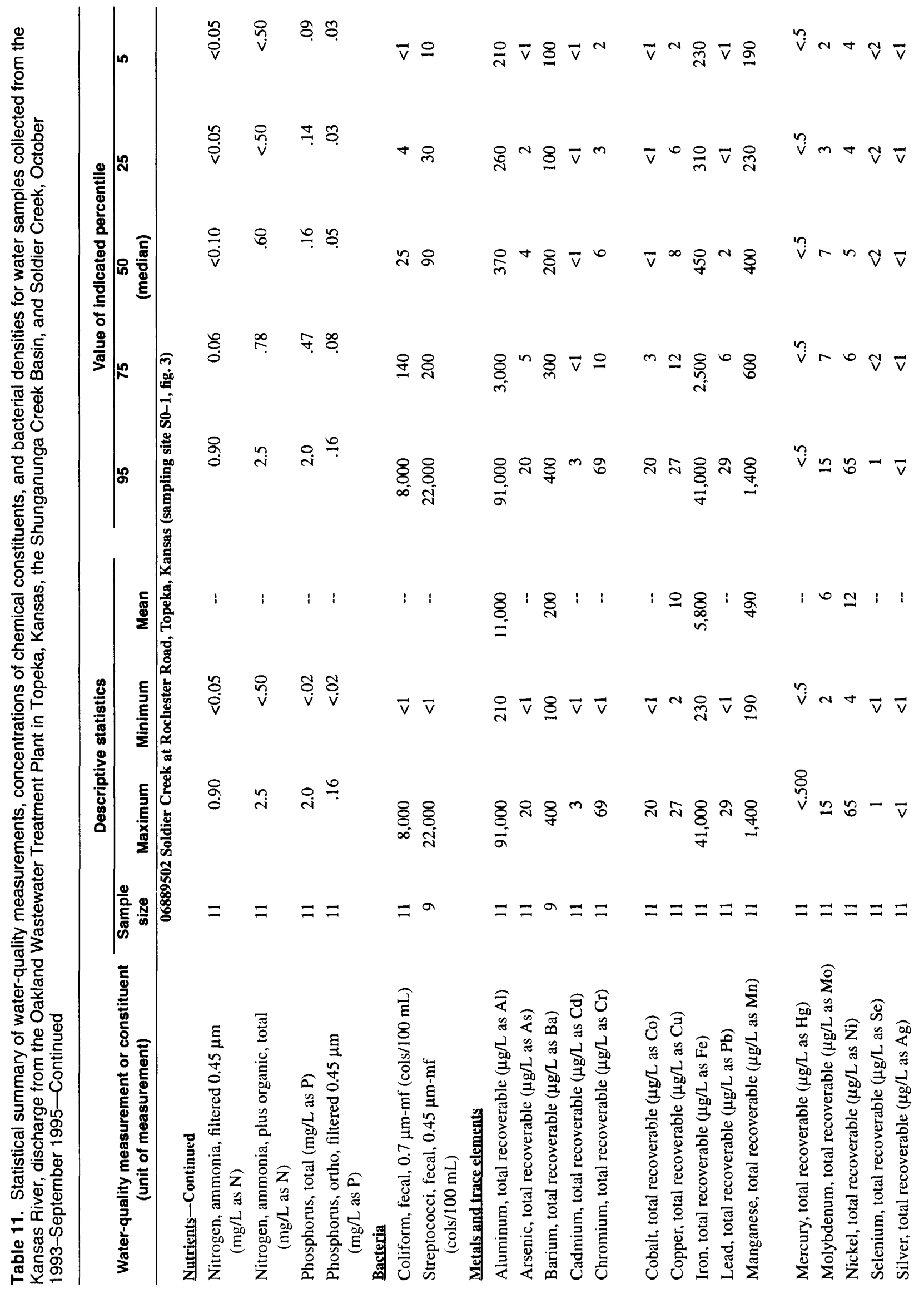

80 Effects of Urbanization on Water Quality in the Kansas River, Shunganunga Creek Basin, and Soldier Creek, Topeka, Kansas, October 1993 Through September 1995 


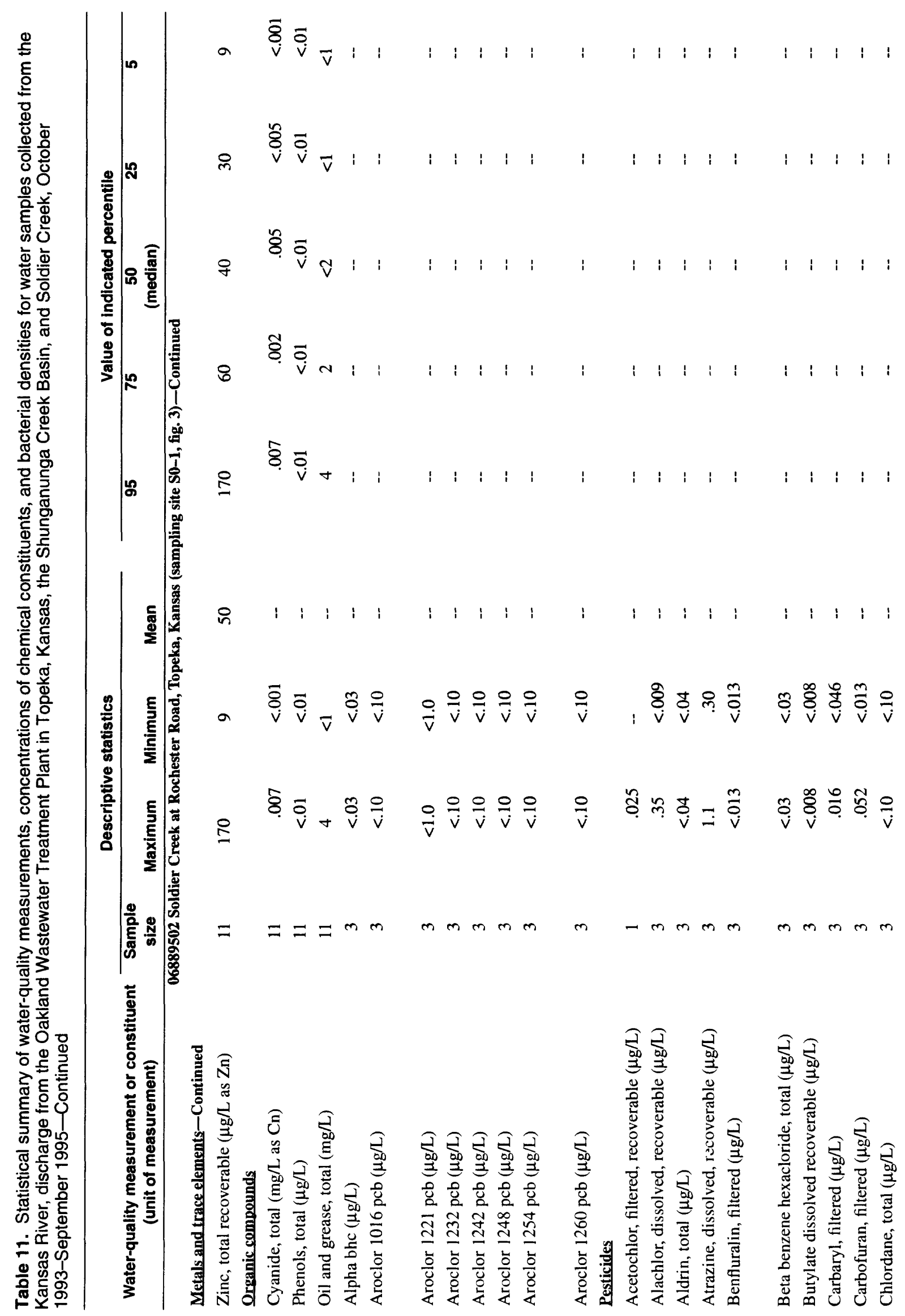




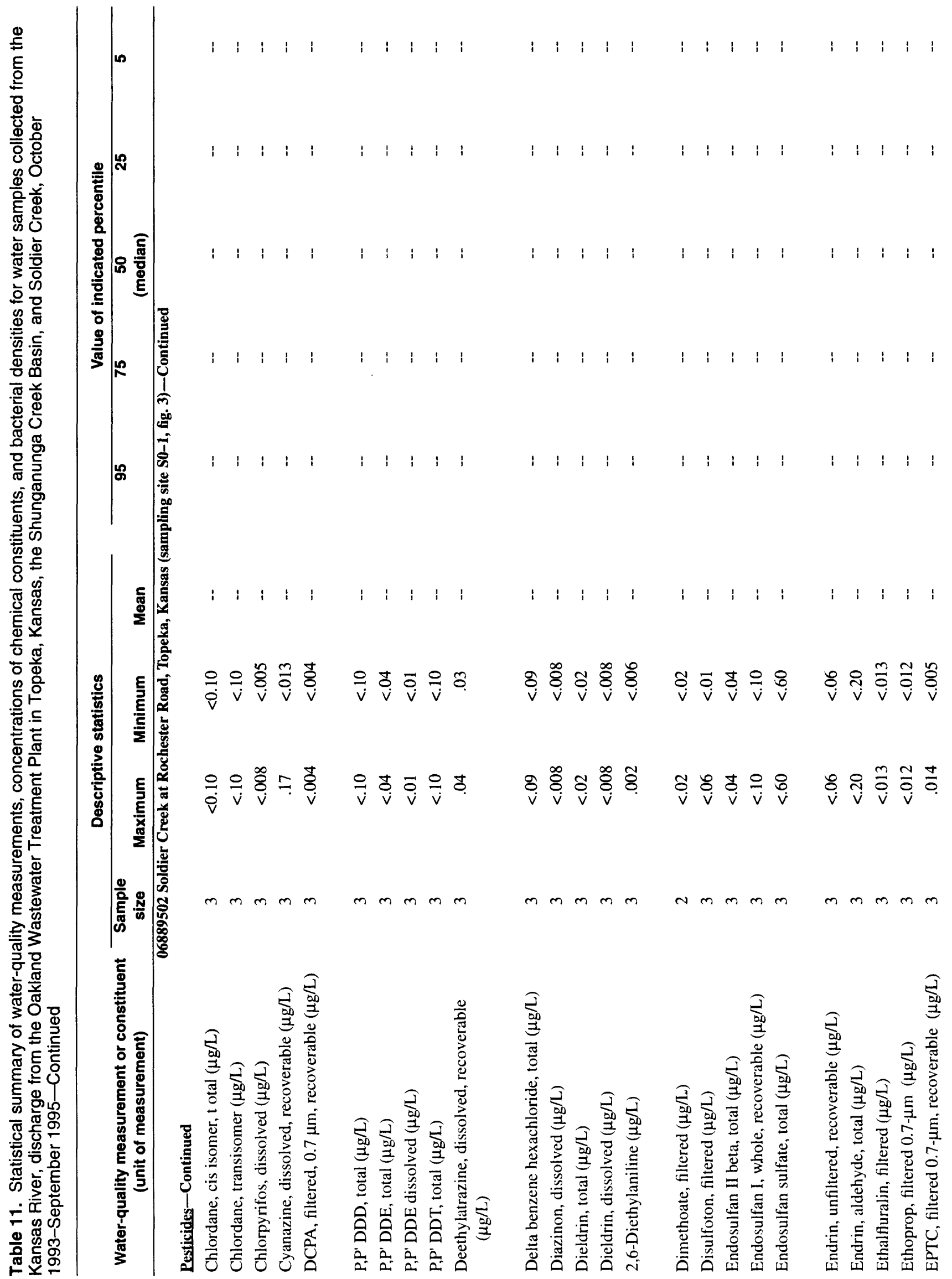

82 Effects of Urbanization on Water Quality in the Kansas River, Shunganunga Creek Basin, and Soldier Creek, Topeka, Kansas, October 1993 Through September 1995 


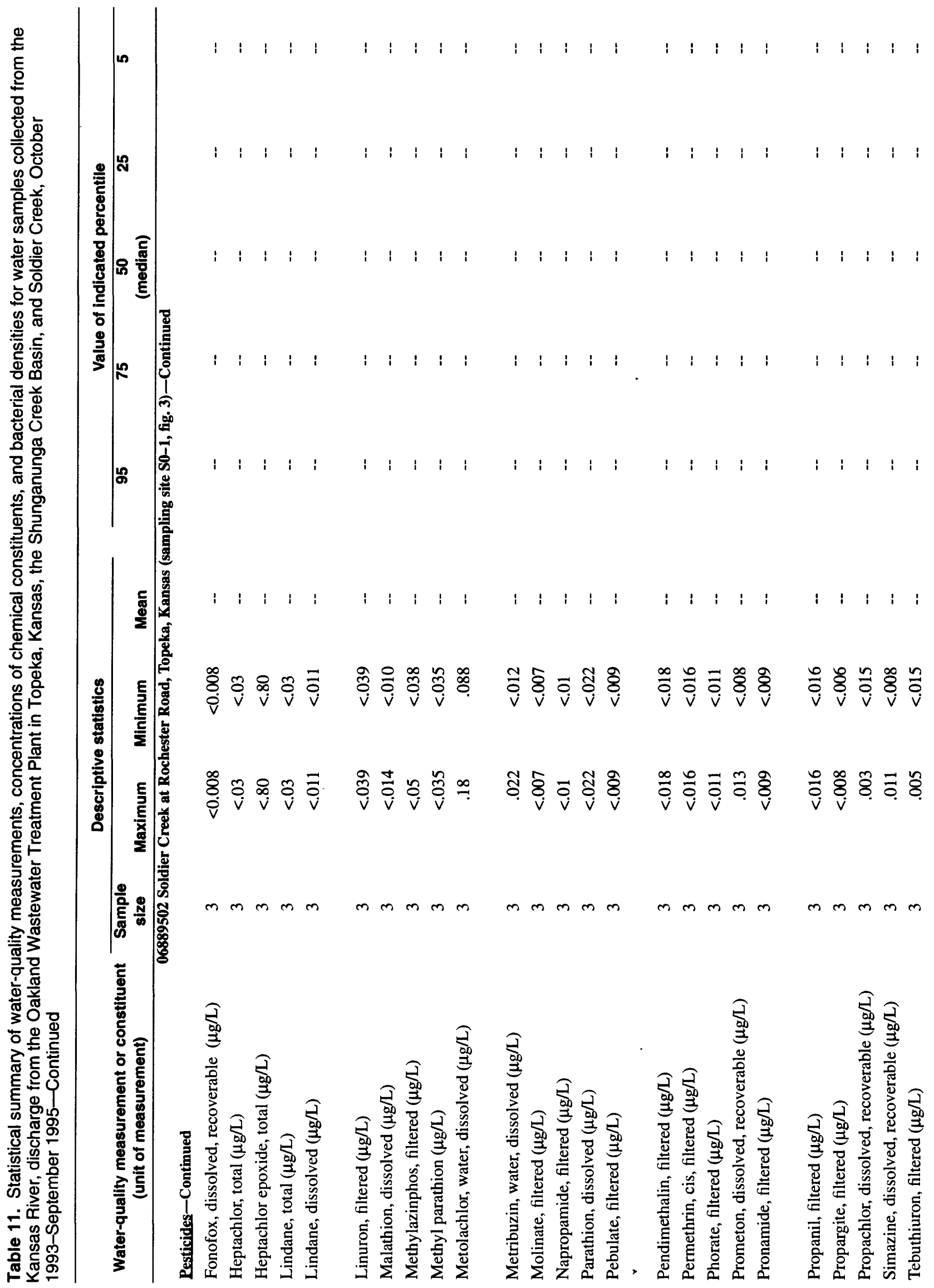




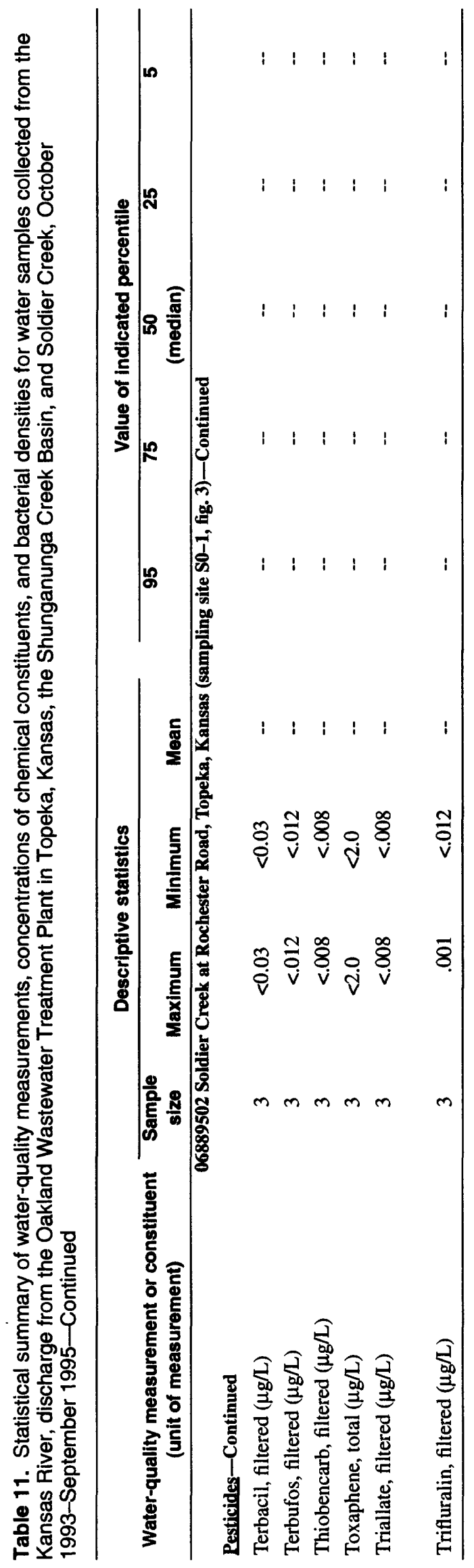

84 Effects of Urbanization on Water Quailty in the Kansas River, Shunganunga Creek Basin, and Soldier Creek, Topeka, Kansas, October 1993 Through September 1995 